\title{
HYDROGEOLOGY, GEOCHEMISTRY, AND QUALITY OF WATER OF THE BASIN AND OAK SPRING AREAS OF THE CHISOS MOUNTAINS, BIG BEND NATIONAL PARK, TEXAS
}

by E.T. Baker, Jr., and Paul M. Buszka

With a section on Seismic-Refraction Surveys, by Dennis G. Woodward

U.S. GEOLOGICAL SURVEY

Water-Resources Investigations Report 93-4112 


\title{
U.S. DEPARTMENT OF THE INTERIOR \\ BRUCE BABBITT, Secretary
}

\author{
U.S. GEOLOGICAL SURVEY
}

Robert M. Hirsch, Acting Director

The use of trade, product, industry, or firm names is for descriptive purposes only and does not imply endorsement by the U.S. Government.

For additional information write to:

Copies of this report can be purchased from:

District Chief

U.S. Geological Survey 8011 Cameron Rd. Austin, TX 78754-3898
U.S. Geological Survey

ESIC, Open-File Reports Section

Box 25286, Mail Stop 517

Denver Federal Center

Denver, CO 80225-0046 


\section{CONTENTS}

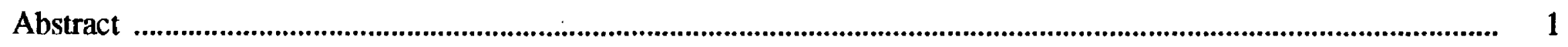

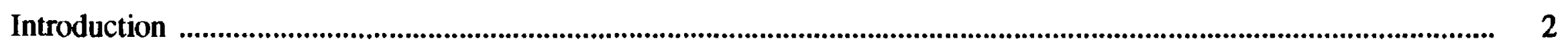

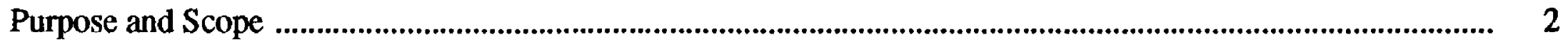

Methods of Investigation and Description of Test Sites ........................................................................ 2

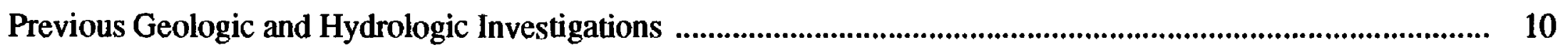

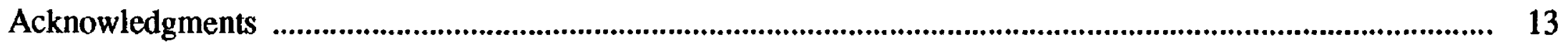

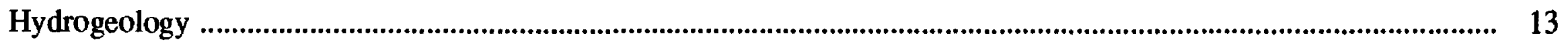

Geology, Landforms, and Hydrologic Setting ........................................................................................... 13

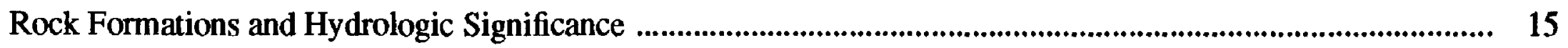

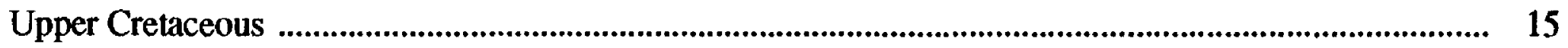

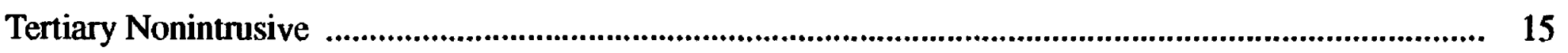

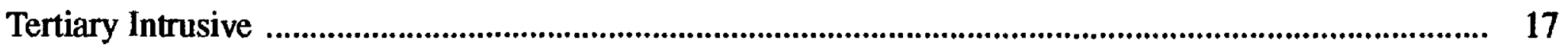

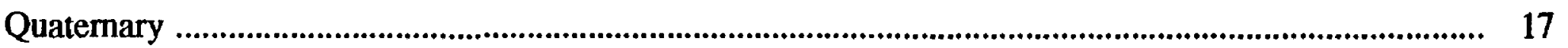

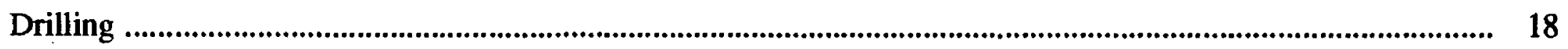

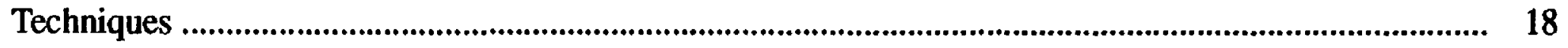

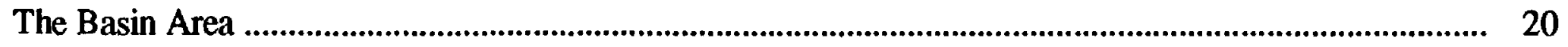

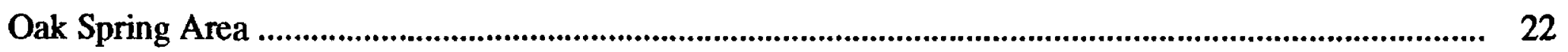

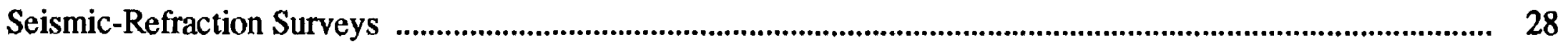

By Dennis G. Woodward

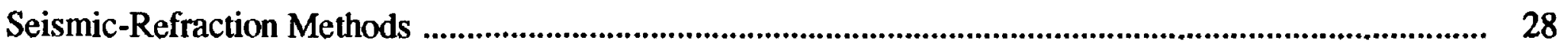

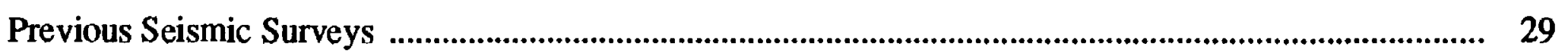

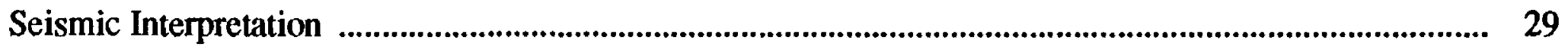

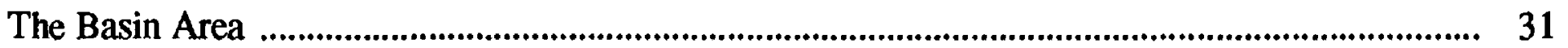

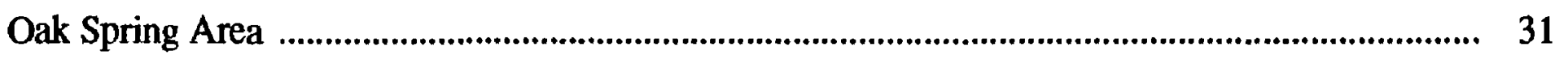

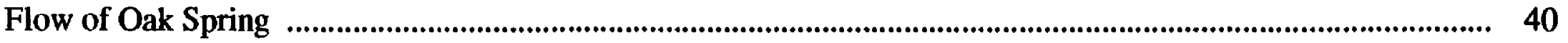

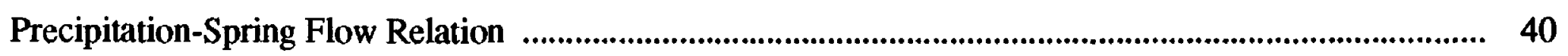

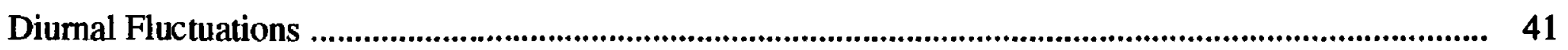

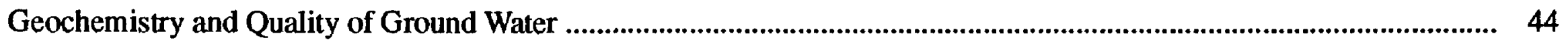

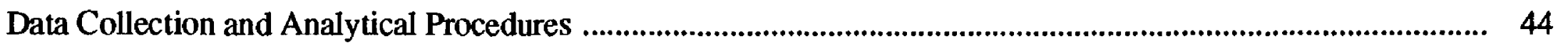

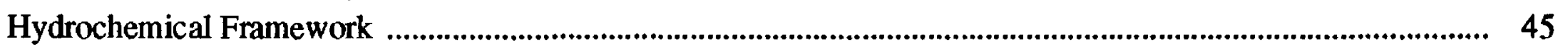

Major and Minor Inorganic Constituents ........................................................................................................ 45

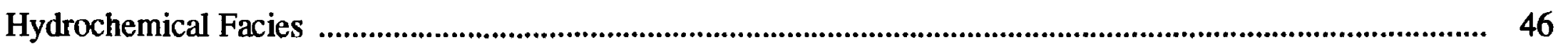

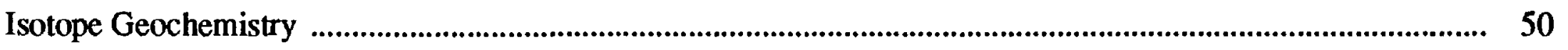

Quality of The Basin and Oak Spring Ground Water .............................................................................................. 52

Effect of The Basin Activities on Ground-Water Quality ......................................................................... 52

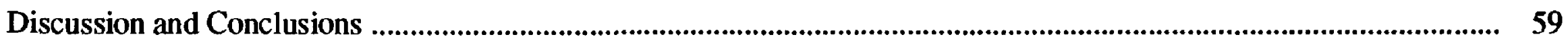

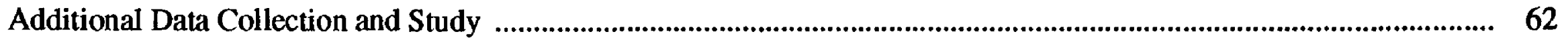

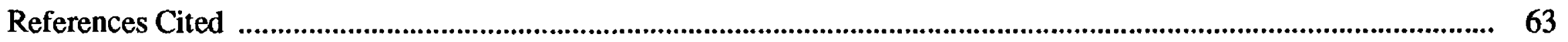

\section{FIGURES}

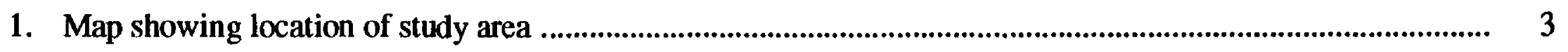

2. Photograph showing view of the Chisos Mountains region including The Basin and Oak Spring areas ............ 4

3. Map showing location and types of test sites in the study area and regional topography ................................... 6 
4-8. Photographs showing:

4. Sewage lagoons on alluvium and colluvium in The Basin ................................................................

5. Top of Window Pouroff near Window Spring ........................................................................................ 8

6. Window Pouroff and waterfall from below in Oak Spring area .......................................................... 9

7. Oak Spring in the lower Oak Creek area:

a. Lower Oak Creek area as seen looking west from Vernon Bailey Peak .............................................. 11

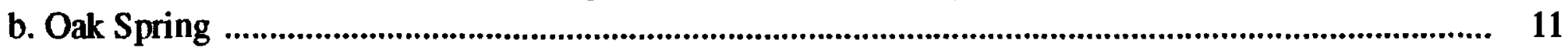

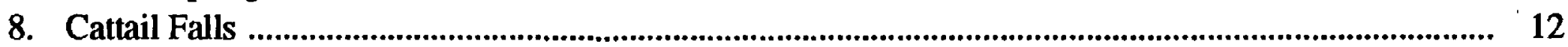

9. Map showing generalized geologic outcrops of the central and western Chisos Mountains ............................... 14

10. Generalized geologic section A-A' along Oak Creek in The Basin and Oak Spring areas ................................. 16

11. Photograph showing alluvium and colluvium in a high bank of a channel of upper Oak Creek ......................... 19

12. Map showing The Basin area and locations of seismic line, test borings, wells, and lagoons ............................ 21

13. Photograph showing test boring TB-3 near lower sewage lagoon ................................................................... 23

14. Map showing Oak Spring area and locations of seismic lines, test borings, and Oak Spring ........................... 24

15. Graph showing profiles of the land surface and borehole logs showing relation to Oak Spring ......................... 26

16. Map showing location of seismic lines shot in Big Bend National Park ........................................................ 30

17-20. Seismic depth profiles showing interpretation of:

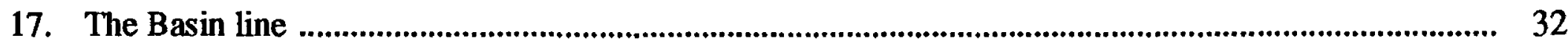

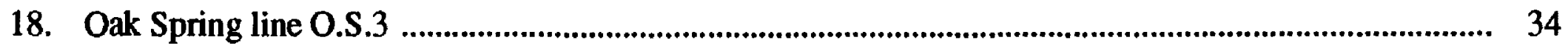

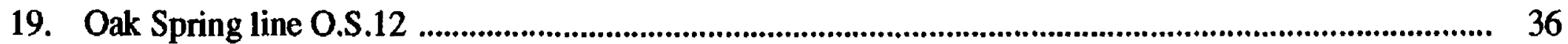

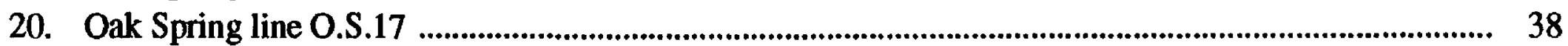

21. Graphs showing daily precipitation in The Basin, January 1986-December 1989, and daily discharge of Oak Spring, December 1986-December 1989 ......................................................................... 42

22. Hydrograph showing diurnal fluctuations in the flow of Oak Spring, July 5-7, 1987 .....................................4. 43

23. Graphs showing relation of specific-conductance values and concentrations of calcium, sulfate, chloride, and nitrate to discharge from Oak Spring

24. Graph showing mineral saturation indices calculated using the program PHREEQE for water samples from The Basin and Oak Spring areas and Cattail Falls, August 1986

25. Trilinear diagrams showing hydrochemical facies for water samples from The Basin and Oak Spring areas and Cattail Falls, 1954-87, and definitions of hydrochemical facies for a typical classification ............

26-28. Graphs showing:

26. Relation between del-deuterium and del-oxygen-18:

a. Among water affected by typical geochemical processes ............................................................. 51

b. In water samples from The Basin and Oak Spring areas and Cattail Falls ........................................ 51

27. Variation of tritium in regional precipitation and in waters of The Basin and Oak Spring areas and Cattail Falls

28. Average annual tritium in precipitation, decay-corrected to 1986 , and tritium in waters of The Basin and Oak Spring areas and Cattail Falls

TABLES

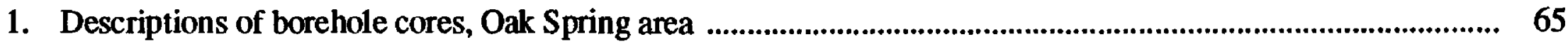

2. Seismic velocity and depth to layers interpreted from refraction survey, Chisos Mountains area ...................... 33

3. Seismic velocities and assigned lithologies for subsurface layers, Chisos Mountains area ................................ 40

4. Water-quality data for selected locations, The Basin and Oak Spring areas and Cattail Falls, 1954-89

5. Summary of maximum contaminant levels and secondary maximum contaminant levels for selected water-quality properties and constituents for public water systems

6. Concentrations of volatile and semivolatile organic compounds in water samples extracted by closed-loop stripping, The Basin and Oak Spring areas, August 1987

7. Results of viral and microbial analyses of water samples, The Basin and Oak Spring areas and Cattail Falls, June 1986 and March 1988 
CONVERSION FACTORS, VERTICAL DATUM, AND ABBREVIATED WATER-QUALITY UNITS

\begin{tabular}{|c|c|c|}
\hline acre-foot (acre-ft) & 1,233 & cubic meter \\
\hline foot $(\mathrm{ft})$ & 0.3048 & meter \\
\hline foot per second $(\mathrm{ft} / \mathrm{s})$ & 0.3048 & meter per second \\
\hline gallon per minute (gal/min) & 0.06308 & liter per second \\
\hline mile (mi) & 1.609 & kilometer \\
\hline ounce (oz) & 0.02957 & liter \\
\hline \multirow[t]{2}{*}{ square mile $\left(\mathrm{mi}^{2}\right)$} & 2.590 & square kilometer \\
\hline & Temperature & \\
\hline
\end{tabular}

Sea level: In this report, "sea level" refers to the National Geodetic Vertical Datum of 1929--a geodetic datum derived from a general adjustment of the first-order level nets of the United States and Canada, formerly called Sea Level Datum of 1929.

\section{Abbrevlated water-quallty unlts:}

cols. $/ 100 \mathrm{~mL}$, colonies per 100 milliliters

L, liter

$\mu \mathrm{g} / \mathrm{L}$, microgram per liter

$\mu \mathrm{m}$, micrometer

$\mathrm{mg} / \mathrm{L}$, milligram per liter

$\mathrm{mL}$, milliliter

$\mathrm{pCi} / \mathrm{L}$, picocuries per liter

TU, tritium unit 


\title{
Hydrogeology, Geochemistry, and Quality of Water of The Basin and Oak Spring Areas of the Chisos Mountains, Big Bend National Park, Texas
}

\author{
By E.T. Baker, Jr., and Paul M. Buszka \\ With a section on Seismic-refraction Surveys, by Dennis G. Woodward
}

\section{Abstract}

Test drilling near two sewage lagoons in The Basin area of the Chisos Mountains, Big Bend National Park, Texas, has shown that the alluvium and colluvium on which the lagoons are located is not saturated in the immediate vicinity of the lagoons. A shallow aquifer, therefore, does not exist in this critical area at and near the lagoons. Should seepage outflow from the lagoons occur, the effluent from the lagoons might eventually be incorporated into shallow ground water moving westward in the direction of Oak Spring. Under these conditions such water could reach the spring. Test borings that bottomed in bedrock below the alluvial and colluvial fill material are dry, indicating that no substantial leakage from the lagoons was detected. Therefore, no contaminant plume was identified. Fill material in The Basin does not contain water everywhere in its extensive outcropping area and supplies only a small quantity of ground water to Window Pouroff, which is the only natural surface outlet of The Basin.

Oak Spring, which is almost 2 miles downgradient from the lagoons, is the sole source of water for The Basin--the principal tourist area in Big Bend National Park. Test drilling in the Oak Spring area revealed that the aquifer in the immediate vicinity of Oak Spring is a 5-foot thick sand bed hydraulically confined above and below by relatively thick, compact clay. The sand bed might be bounded locally by faults to the east and west of the spring. The test drilling and seismic surveys in the area also established the existence of a thick, extensive, surficial layer of colluvium consisting of large rhyolite boulders. The colluvial layer, which overlies sedimentary bedrock containing the Oak Spring aquifer, was unsaturated at the borehole sites.

Information from drilling and from hydrogeologic observation indicates that the water from Oak Spring originates as precipitation in the Oak Spring area west of The Basin, with possibly a contribution originating as discharge from The Basin. The rhyolite boulder field in the Oak Spring area, which includes talus from Vernon Bailey Peak, is an effective receptacle for rapid recharge of precipitation. This water could then be efficiently routed into the Oak Spring aquifer in places to the east of Oak Spring where any shallow ground water in the boulder field might enter the subcropping truncated aquifer.

Water-chemistry data, hydrochemical facies, and isotopic data also indicate that water from Oak Spring originates principally from precipitation onto the land surface of the Oak Spring area. Tritium data indicate that Oak Spring water is "modern," with an average age of recharge less than 14 years. The flow rates recorded almost continuously at Oak Spring beginning in December 1986 show a close relation between precipitation and discharge. The highest recorded spring flow of 167 gallons per minute in December 1986 is attributed to record high precipitation in the area during 1986. The lowest recorded flow of 22.4 gallons per minute, in December 1989, followed a period of 20 out of 26 months of below-normal precipitation. Flow at Oak Spring typically lags behind precipitation by about 1 month. This fairly rapid response indicates the spring is fed by a shallow aquifer having good permeability and effective recharge areas with the ability to absorb precipitation rapidly. 


\section{INTRODUCTION}

Big Bend National Park is in southem Brewster County in west Texas (fig. 1). In this area along the Mexican border, an approximate 90-degree bend of the Rio Grande marks the southem extremity of the park. The Chisos Mountams in the central part of the park rise several thousand feet above the surrounding plain and are a natural focal point of interest. The Basin, a topographic and structural depression in the northwestem part of the Chisos Mountains, is surrounded by high peaks and ridges. It is here that the cultural development of the park is centered--motel, cabins, lodge and restaurant, store, ranger station, campground, horse corral, and sewage-treatment plant and lagoons. The Oak Spring area is in the foothills just west of and at a lower elevation than The Basin. Oak Spring is the sole source of water for all development in The Basin. A photographic overview of the region, including The Basin and Oak Spring areas, is shown in figure 2.

Sewage from tourist facilities in The Basin undergoes secondary treatment in a sewage-treatment plant installed in 1963, and treated effluent is disposed of in two lagoons within The Basin. The National Park Service is concerned that the water of Oak Spring, which is $1.8 \mathrm{mi}$ downslope from the sewage lagoons and along the same drainage course--Oak Creek--might become contaminated by possible leakage from the lagoons to the aquifer that supplies the spring. To address that concem, the U.S. Geological Survey, in cooperation with the National Park Service, made a study to determine the source of Oak Spring with regard to the potential for its contamination from activities in The Basin.

The major objectives of the project were to describe: (1) The hydrogeology of the area that supplies water to Oak Spring, and (2) the potential for contamination of the spring flow. More specifically, comprehensive hydrologic information was needed in The Basin and Oak Spring areas to identify the source(s) of water supplying the spring and to determine if the source(s) include seepage outflow from the sewage lagoons.

\section{Purpose and Scope}

This report presents hydrogeologic findings at the Basin and Oak Spring areas through December 1989 , when the project was terminated. Included here are all basic data resulting from the comprehensive water-quality sampling program and all pertinent interpretations. The basic data are mainly in the tables. Interpretations are given throughout the report, and a general summation is presented under "Discussion and Conclusions."

\section{Methods of Investigation and Description of Test Sites}

Five methods of investigation were used to achieve the objectives. These included: (1) Investigating the area's complex geology by literature search and field work; (2) drilling test holes to obtain hydrogeologic information and to install monitoring wells; (3) conducting seismic surveys in crucial areas; (4) detailed sampling and analysis to determine the geochemistry and quality of the ground water; and (5) instrumenting Oak Spring to obtain continuous records of the fluctuations in flow.

Test sites were numerous and varied; all were in or near The Basin and Oak Spring areas. The types of test sites (well, test borings, springs, weir and stage recorder, seismic lines, and others) in the study area are located and identified in figure 3.

In The Basin area, the hydrogeologic and hydraulic characteristics of the lagoons (altitude 4,900 $\mathrm{ft}$ ) along upper Oak Creek have been intensively investigated. Effluent in the two sewage lagoons (fig. 4) (usually less than about 10 acre-ft) and ground water in the lower Civilian Conservation Corps (CCC) well (State no. BK-73-46-803) in the channel of upper Oak Creek upslope from the lagoons were focal points of sampling for detailed analysis. Four test borings were drilled in the lagoon area to determine (1) the thickness of the alluvium and colluvium on which the lagoons are located, (2) whether saturation is present, and (3) whether contamination from seepage of the effluent is occurring. To map the shallow subsurface, a seismic survey was conducted from near TB-1 to near the lower CCC well.

Water from Window Spring (altitude about 4,480 $\mathrm{ft}$ ) (State no. BK-73-46-804) at the westem end of The Basin also was analyzed in detail. The quality of water from this site of ground-water discharge near The Window might represent the quality of ground water from various sources within The Basin before it flows over Window Pouroff and enters lower Oak Creek (figs. 5 and 6). 


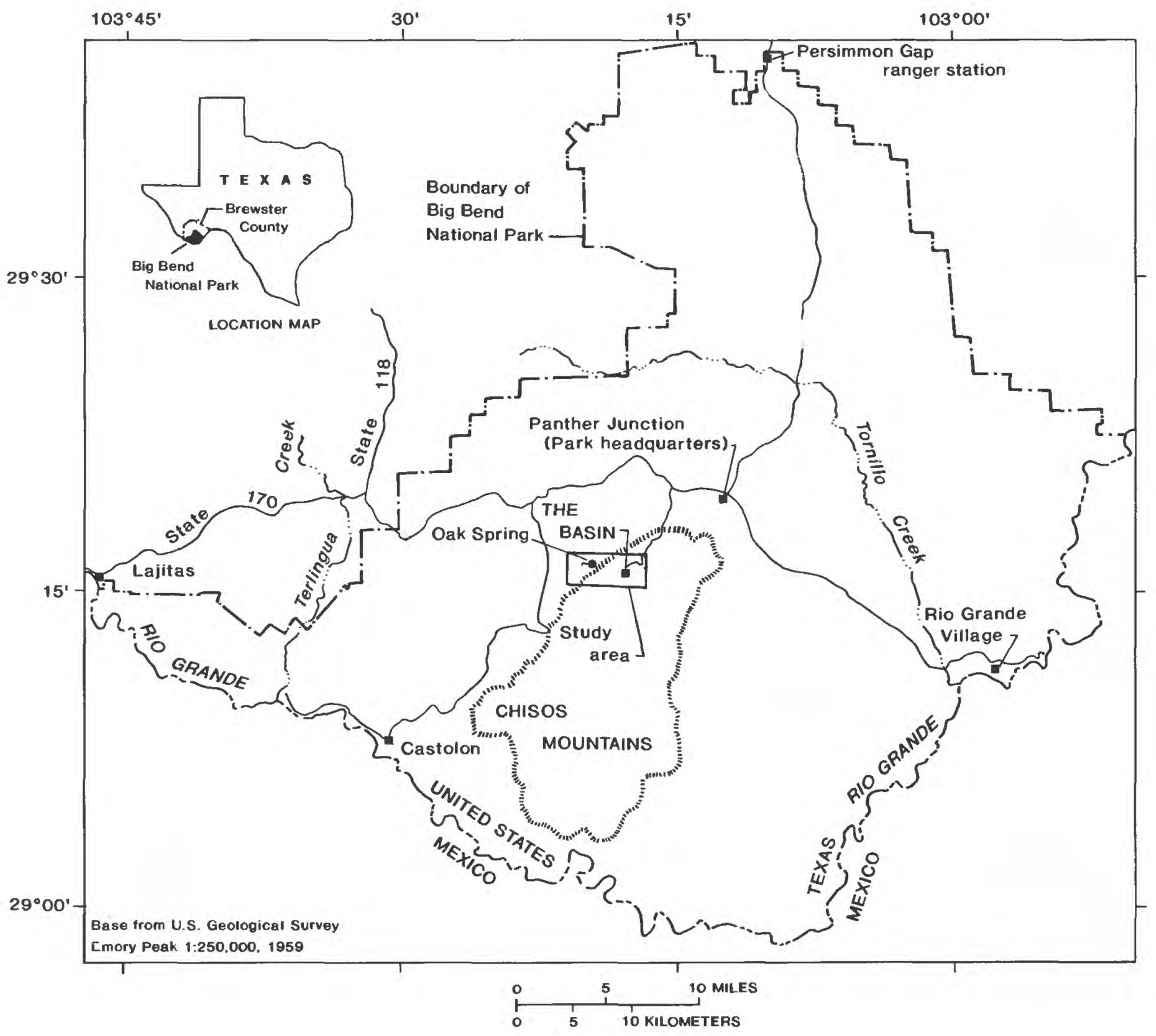

Figure 1. Location of study area. 


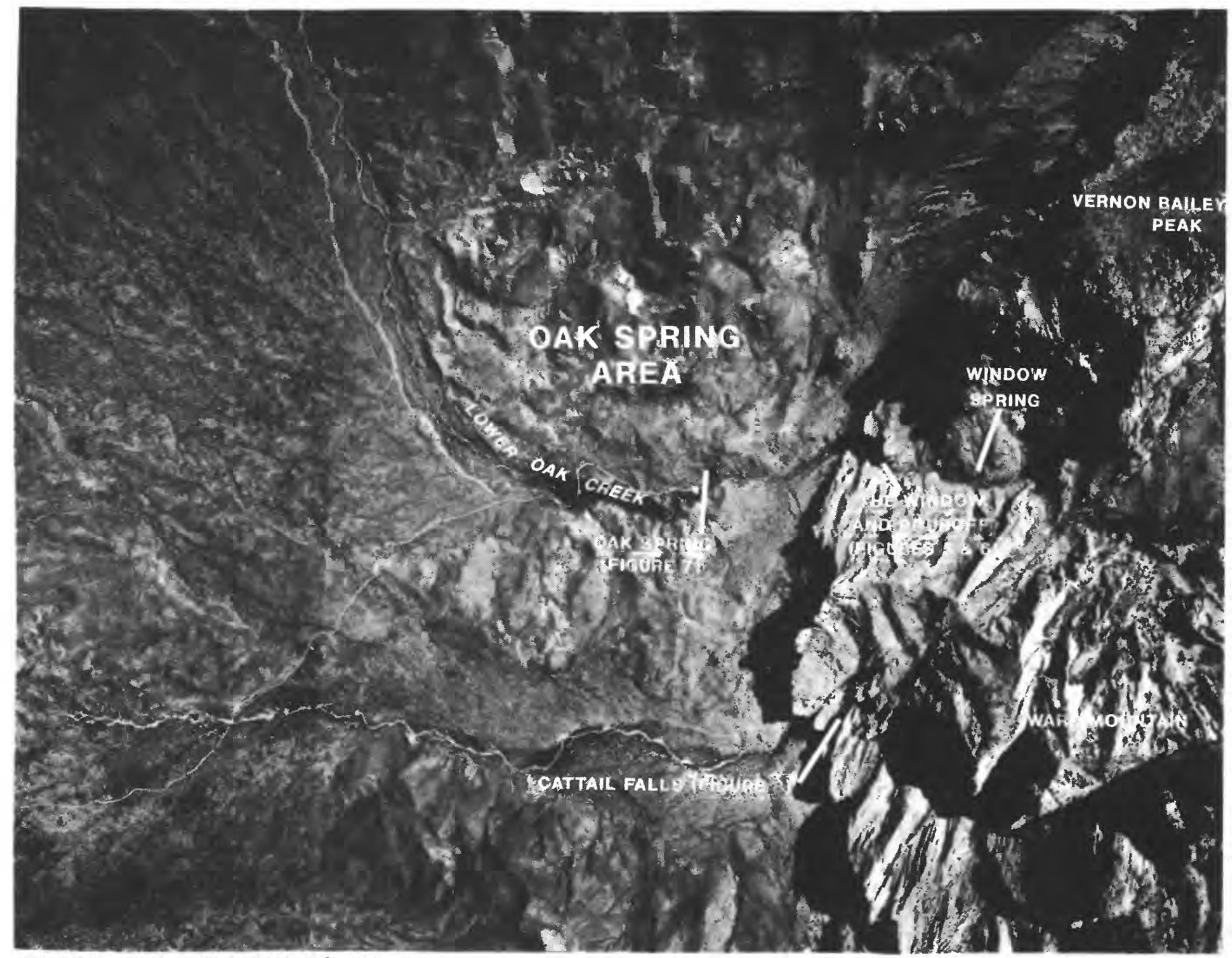

Aerial photomap by U.S. Geological Survey

Aerial photograph by International Aerial Mapping Co., July 1986

Figure 2. View of the Chisos Mountains region including The Basin and Oak Spring areas. 


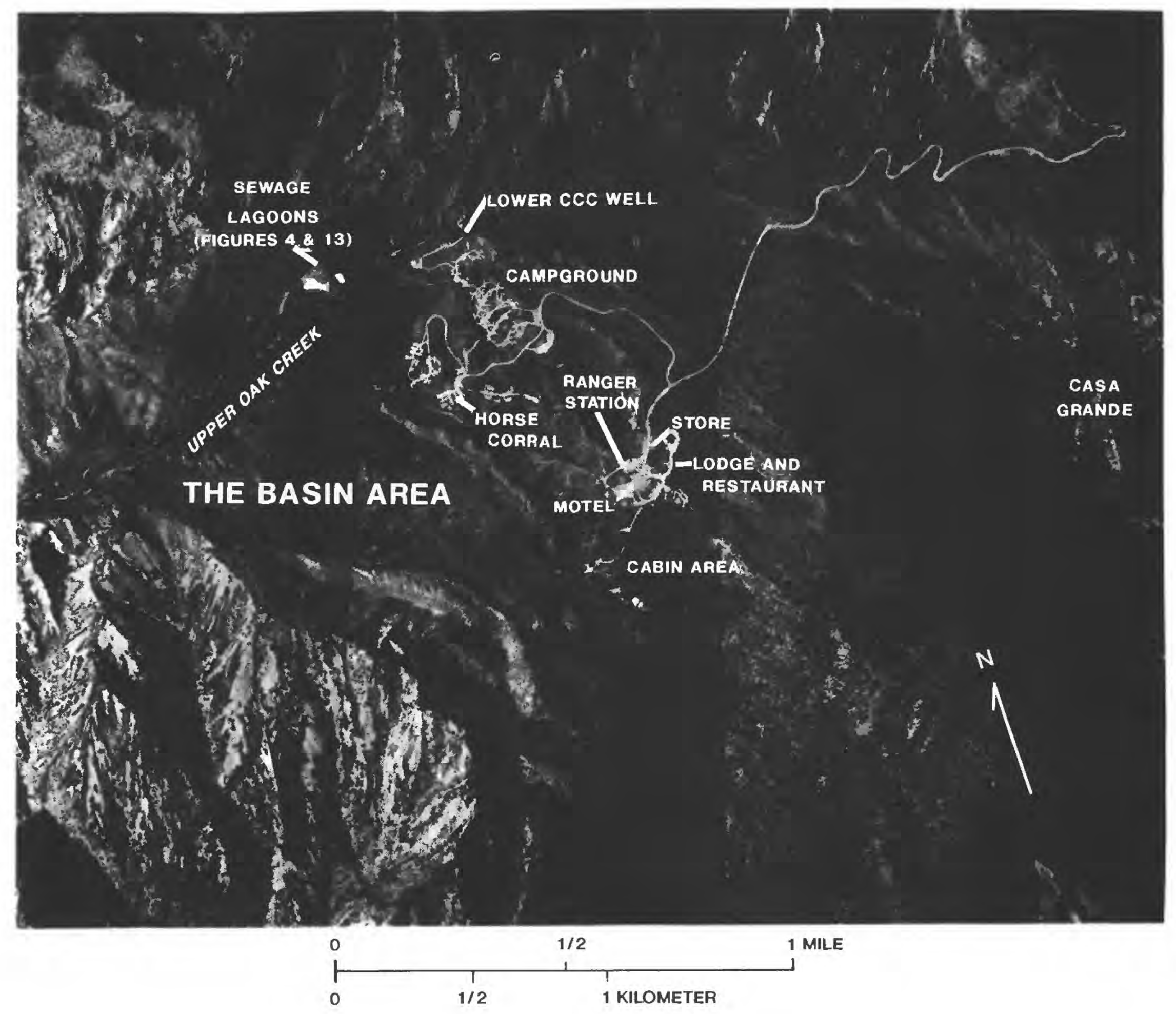




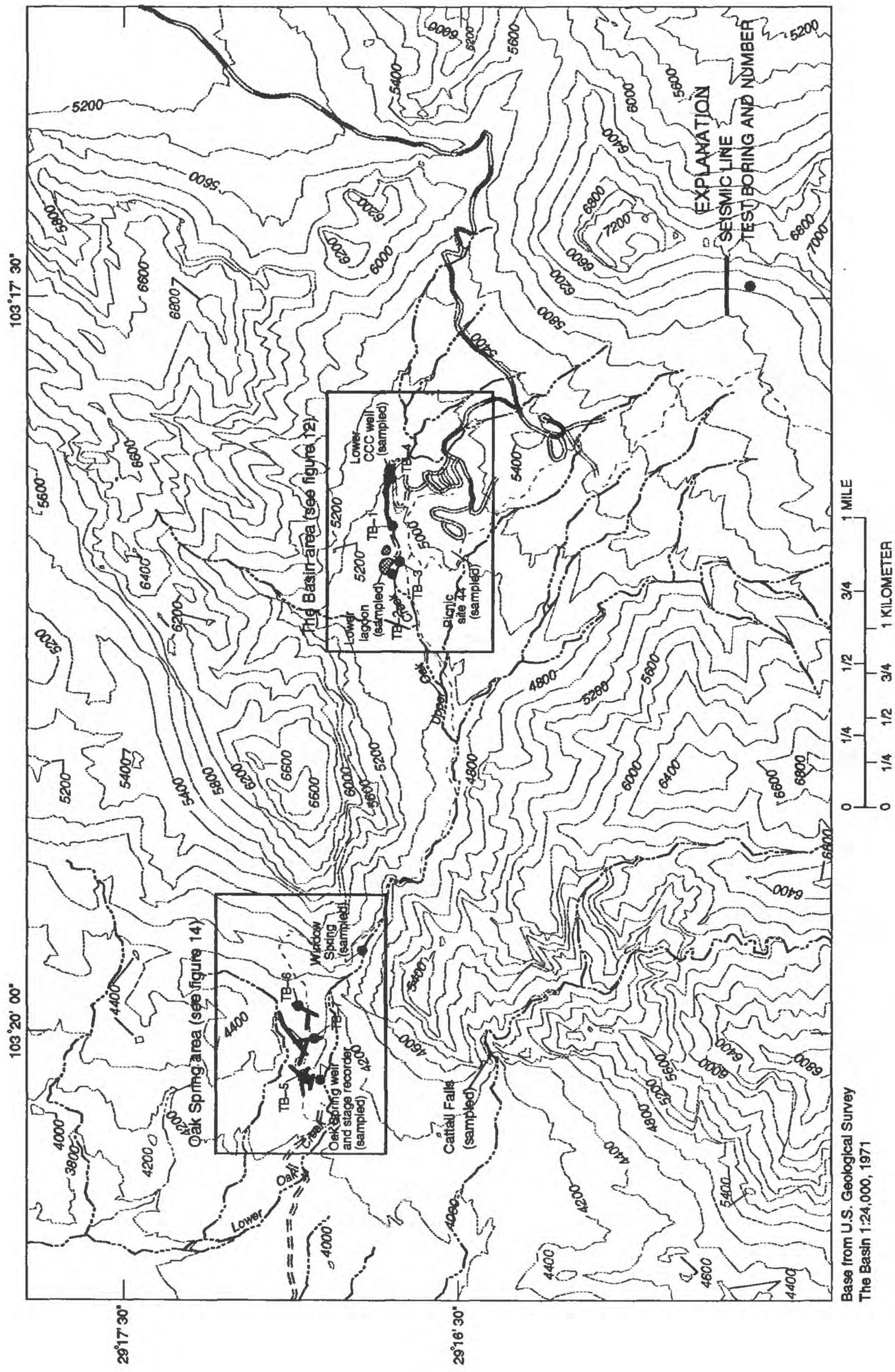

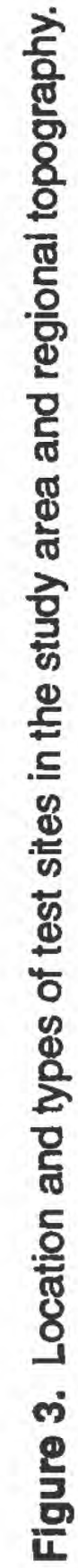




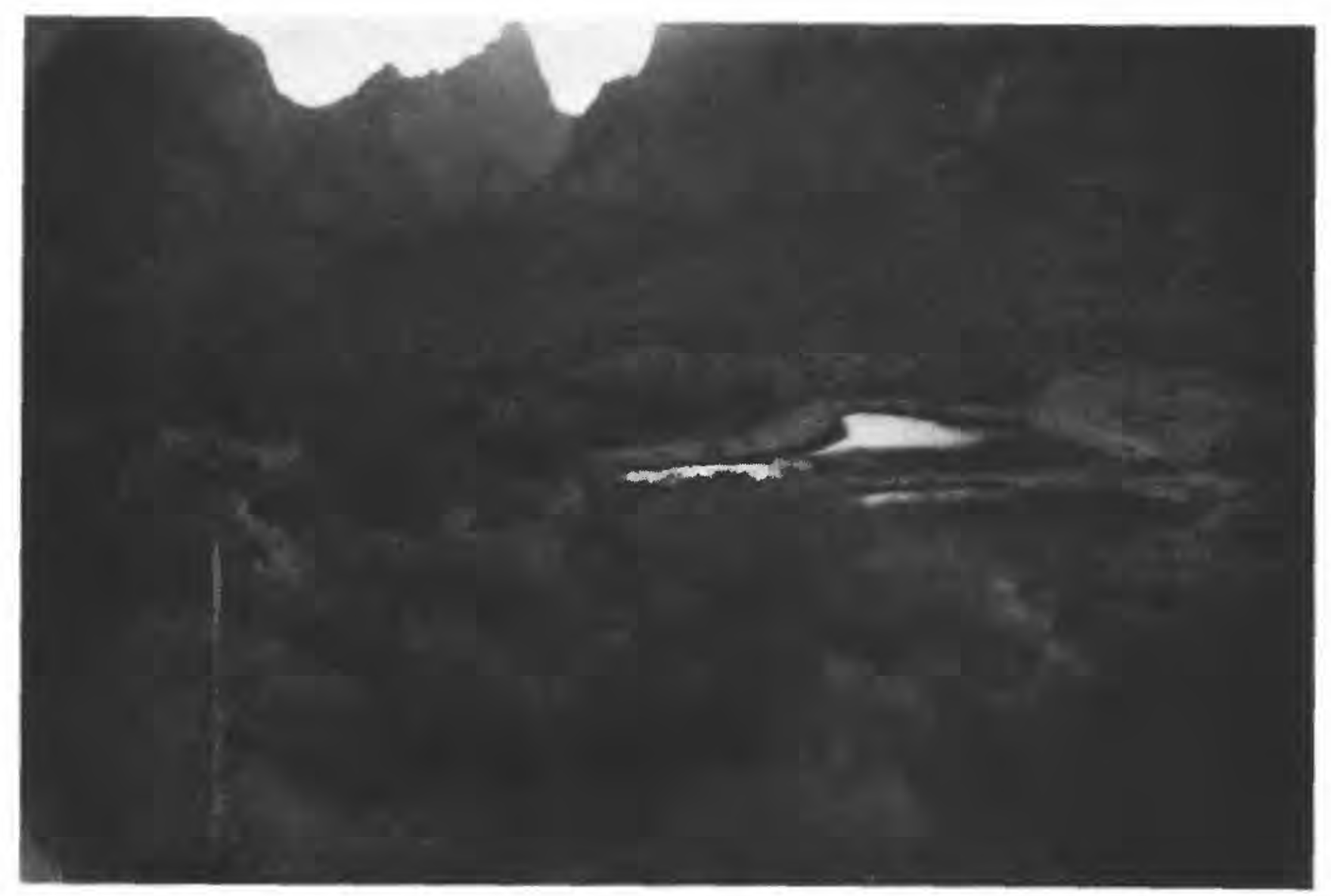

Figure 4. Sewage lagoons on alluvium and colluvium in The Basin. Oak Spring, outside The Basin and the sole source of water for The Basin, is 1.8 miles downgradient from the lagoons and along the same drainage course. Photograph by E.T. Baker, Jr. 


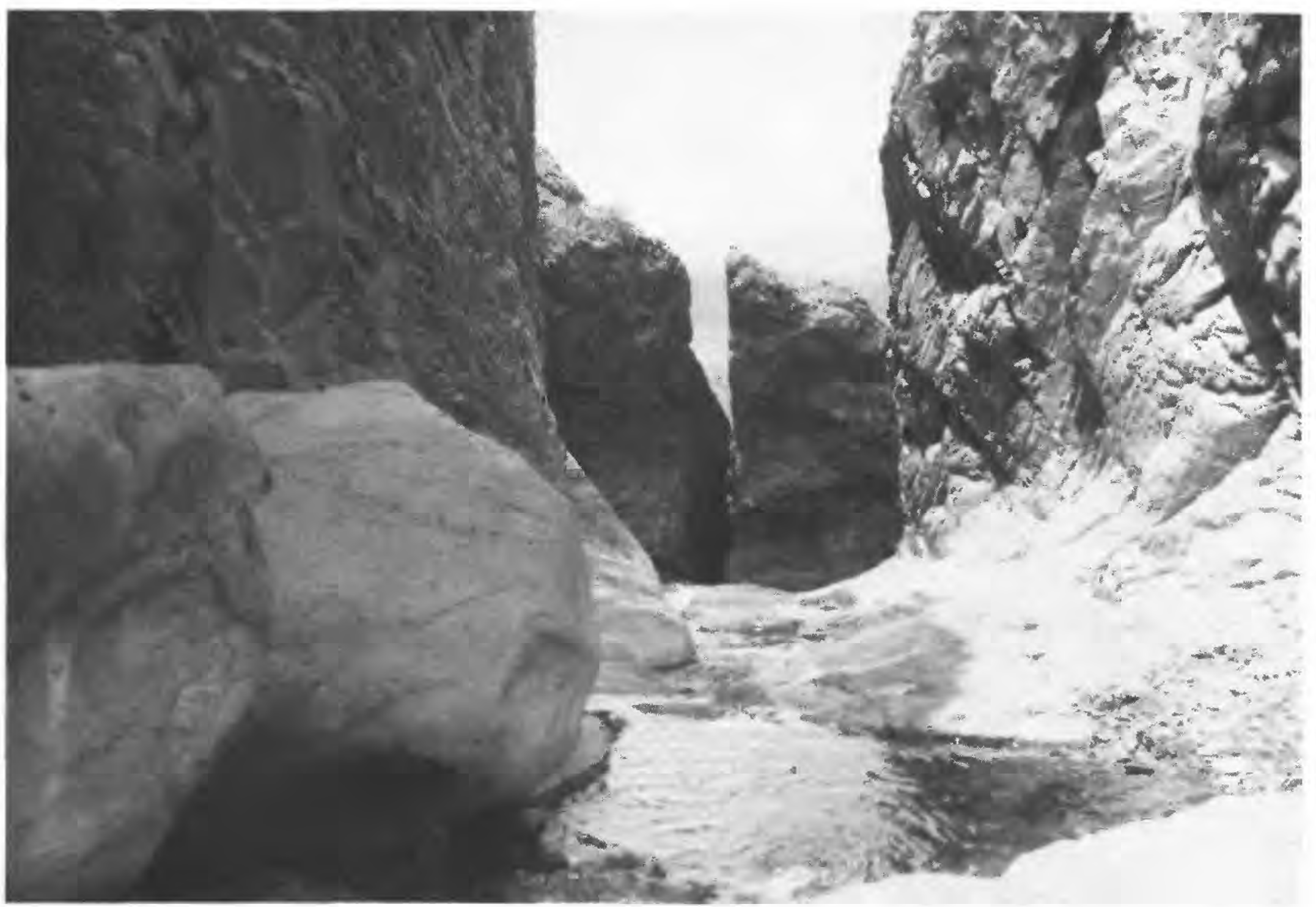

Figure 5. Top of Window Pouroff near Window Spring. The flow shown here on June 25, 1986, was 9 gallons per minute. Photograph by E.T. Baker, Jr. 


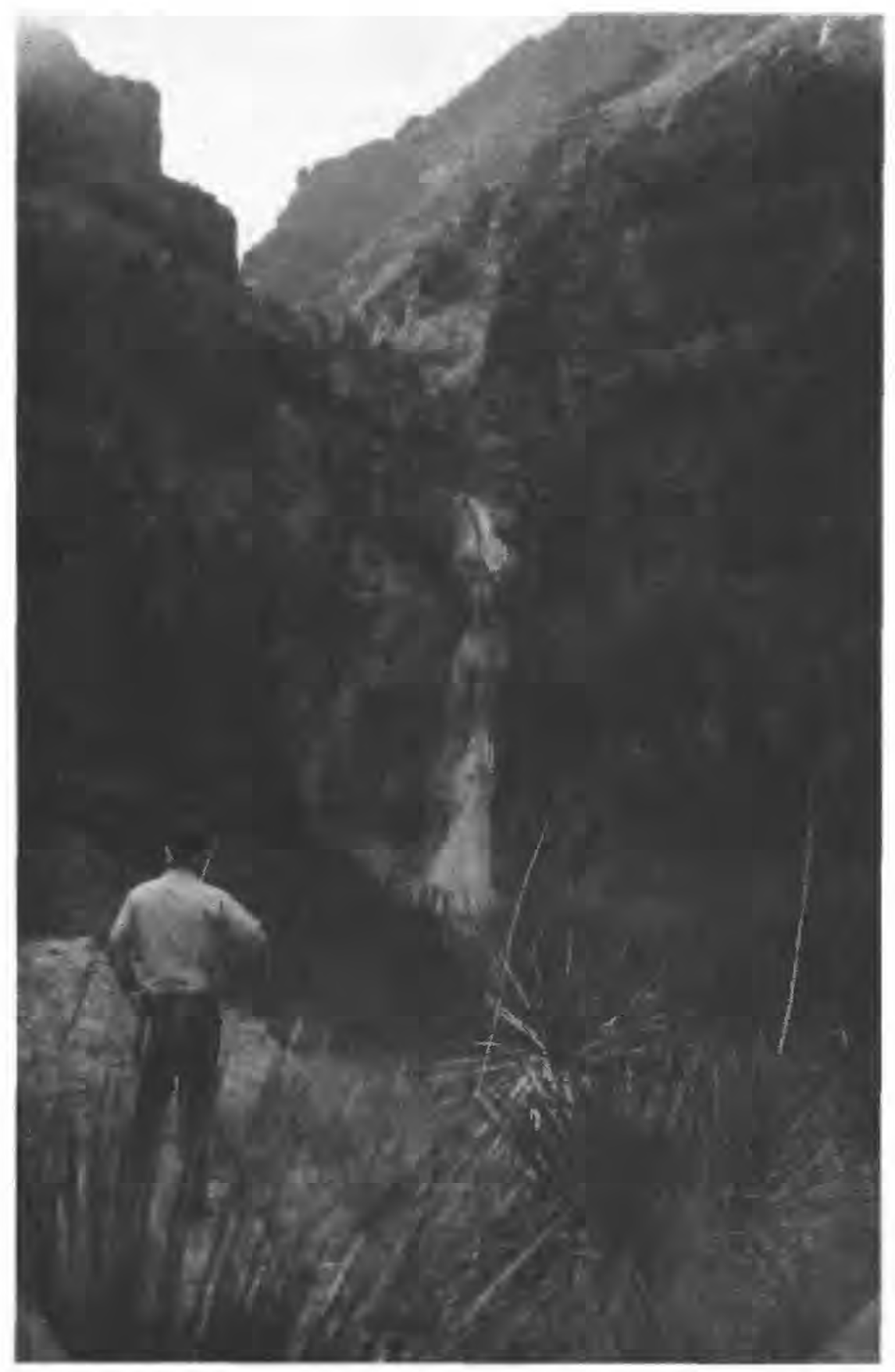

Figure 6. Window Pouroff and waterfall from below in Oak Spring area. The water represents discharge from Window Spring that feeds lower Oak Creek. Photograph by E.T. Baker, Jr. 
Test sites within the Oak Spring area (fig. 3) include water sampling sites at Oak Spring, Window Spring, and at Cattail Falls south of the Oak Spring area, a weir and stage-recorder site at Oak Spring, numerous seismic survey lines to map the shallow subsurface, and three test borings to identify the aquifer supplying water to Oak Spring and, if possible, to identify the aquifer's recharge zone. Test borings were drilled and seismic lines shot on upland north and east of Oak Spring. Oak Spring (altitude 4,080 ft) (State no. BK-73-46-701) was the principal water sampling point (fig. 7). Several types of samples were taken from the spring for detailed and complete analysis in an effort to thoroughly evaluate the quality of the water and to determine the source area of the spring. The recording gaging station at Oak Spring provided continuous stage data, which were converted to discharge using a rating table. These data were compared with precipitation data to evaluate the precipitation-discharge relation. Detailed chemical and biological analyses were conducted on water samples collected at Cattail Falls (State no. BK-73-46-702). Except for overland runoff from precipitation, water from the falls is from spring flow a short distance back from the top of Cattail Falls (fig. 8) and from other springs about $2 \mathrm{mi}$ up Cattail Canyon, as shown on detailed Geological Survey topographic maps.

\section{Previous Geologic and Hydrologic Investigations}

Many scientific investigations have been made in Big Bend National Park. Some were made before the park was established in 1944, but the most comprehensive studies, as well as local detailed studies, of the geology and hydrology have been conducted since then. Many of the investigations were sponsored by the Park Service either to advance scientific knowledge or to find answers to pressing problems.

Dr. Ross A. Maxwell, the first superintendent of Big Bend National Park, compiled the most comprehensive treatise on the geology of the park (Maxwell and others, 1967). This work was done sporadically over 20 years, from 1941 to 1961, and is considered the standard reference on the geology of the park.

Numerous hydrologic studies have been done for the Park Service by the Geological Survey in Big Bend National Park. Most of these studies addressed shortterm and long-term concerns, with the results of the investigations being released to the Park Service as administrative or open-file reports (Baker, 1958; Leggat, 1963; and Rawson, 1963). Many hydrologic investigations in the 1960's and 1970's were conducted under the direction of Edward R. Leggat of the Geological Survey, but results were not published. The earliest short-term study by the Geological Survey was in 1953 and involved a potential water supply on Tomillo Creek, north of Panther Junction (fig. 1). Additional studies followed in the 1950 's and continued in each succeeding decade when occasion demanded. These investigations varied in scope from comprehensive inventories of wells and springs to attempts to locate local water supplies for ranger stations or tourist facilities in remote areas. Ambitious programs were undertaken to insure long-term water supplies, such as the studies (results unpublished) in the 1960's and 1970's in the Panther Junction area; here, numerous sites were selected for the drilling of production wells and, in some cases, for the drilling of hydrologic test holes. In May and June 1973, the deepest test hole was drilled to a depth of 3,471 ft in the "K-Bar" area, 3 mi southeast of Panther Junction; it was deepened in April 1974 and bottomed in non-water-bearing rhyolite at $4,175 \mathrm{ft}$.

Prior to the current study, no previous hydrogeologic studies of a detailed nature have been made by the Geological Survey in The Basin or Oak Spring areas, although there have been several attempts over the last 50 years to locate water supplies in local areas of need. In The Basin, two of the early supply wells were the twin CCC wells dug to depths of 30 to $40 \mathrm{ft}$ in $1936 \mathrm{in}$ the channel of upper Oak Creek. Four shallow wells reportedly were dug in this same area during 1934-36 (Dr. Ross A. Maxwell, Big Bend National Park, oral commun., 1987; and Maxwell, 1985, p. 52), and these wells are the earliest known wells in The Basin. In an attempt to locate a water supply in The Basin, the deepest hole was drilled in 1947 to a depth of $1,160 \mathrm{ft}$ in a steeply sloping arroyo about one-third mile south of the present lodge and restaurant. Water was found at two levels, and tests indicated that the well would yield 25 to $30 \mathrm{gal} / \mathrm{min}$; the well reportedly failed after 4 months of operation (Maxwell, 1985, p. 70).

In the Oak Spring area, only infrequent measurements of the flow of Oak Spring and Cattail Falls and sampling of the waters for chemical analysis were made over the last 30 years. These took place during regional hydrologic studies by the Geological Survey. In the 1980's, hydrologic studies made under the auspices of Texas A\&M University provided isotopic and 


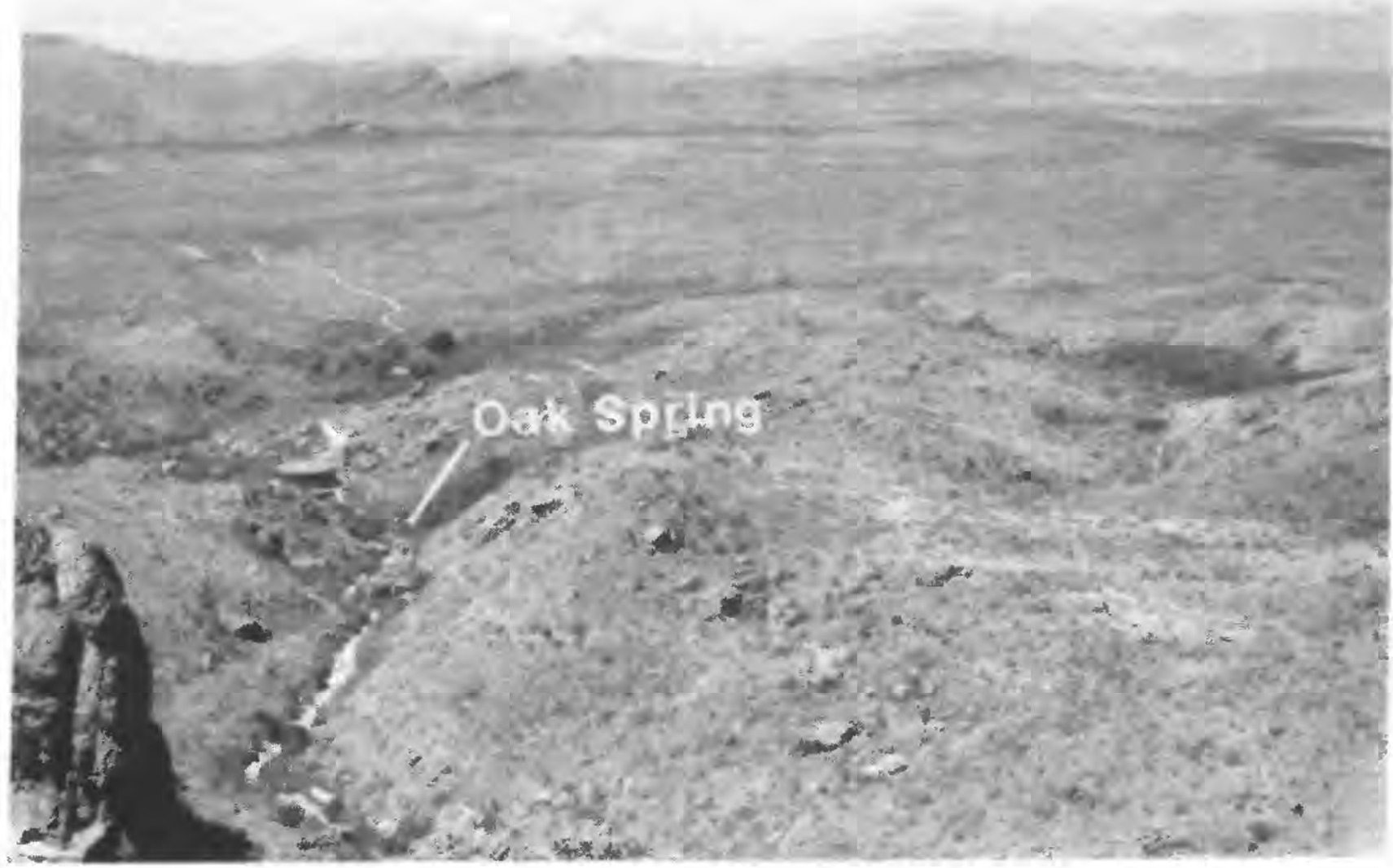

a. Lower Oak Creek area as seen looking west from Vernon Bailey Peak. Oak Spring, in the vegetative area, is less than half a mile from Window Pouroff. Test borings were drilled and seismic lines shot on upland north and east of Oak Spring. Photograph by E.T. Baker, Jr.

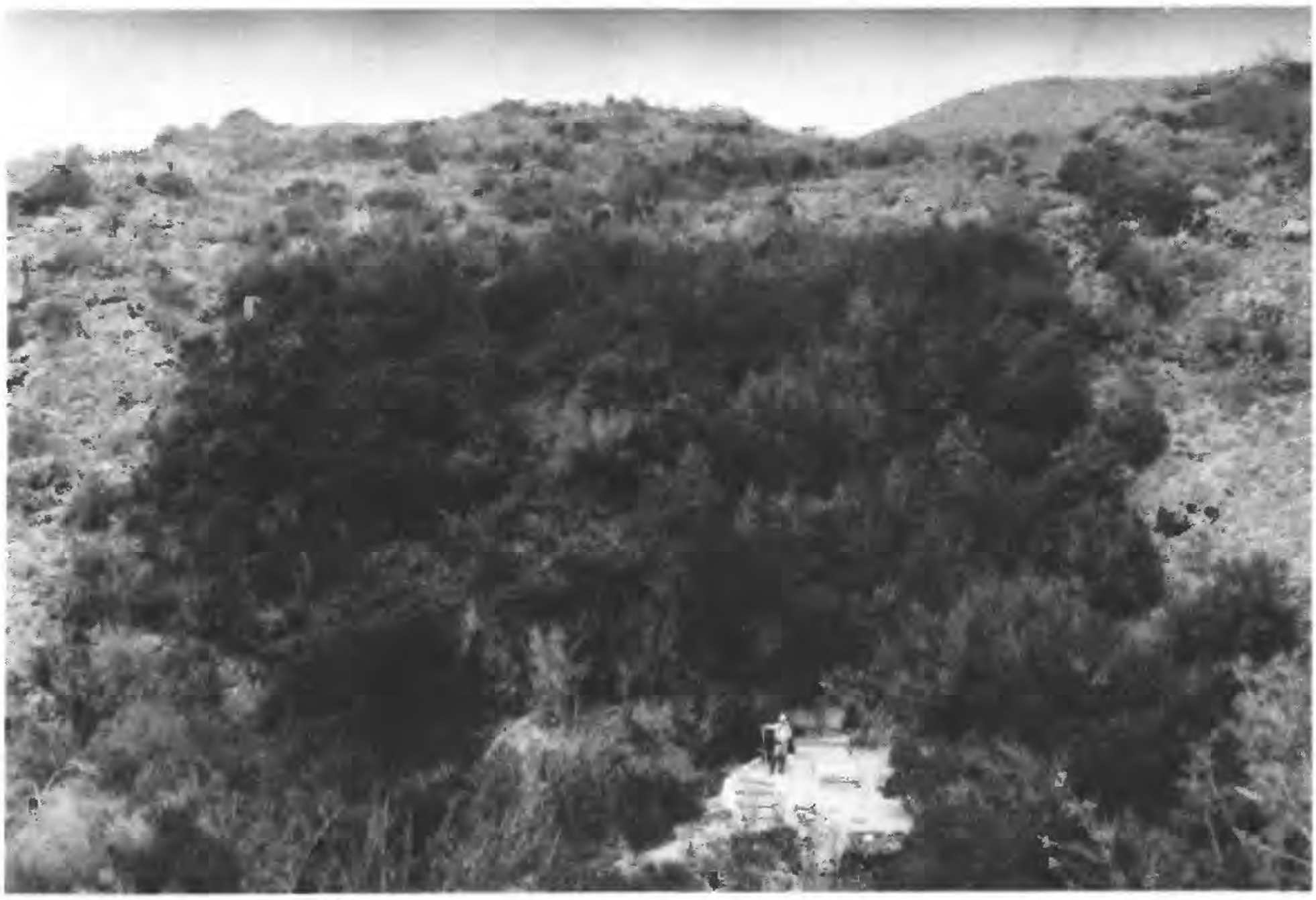

b. Oak Spring. Person in photograph marks the location of the point of discharge. A luxurient growth of vegetation extends up the steep slope The sharp vegetation changes to the right and left of the spring are possibly fault barriers beneath the overburden. View is to the north. Photograph by E.T. Baker, Jr.

Figure 7. Oak Spring in the lower Oak Creek area. 


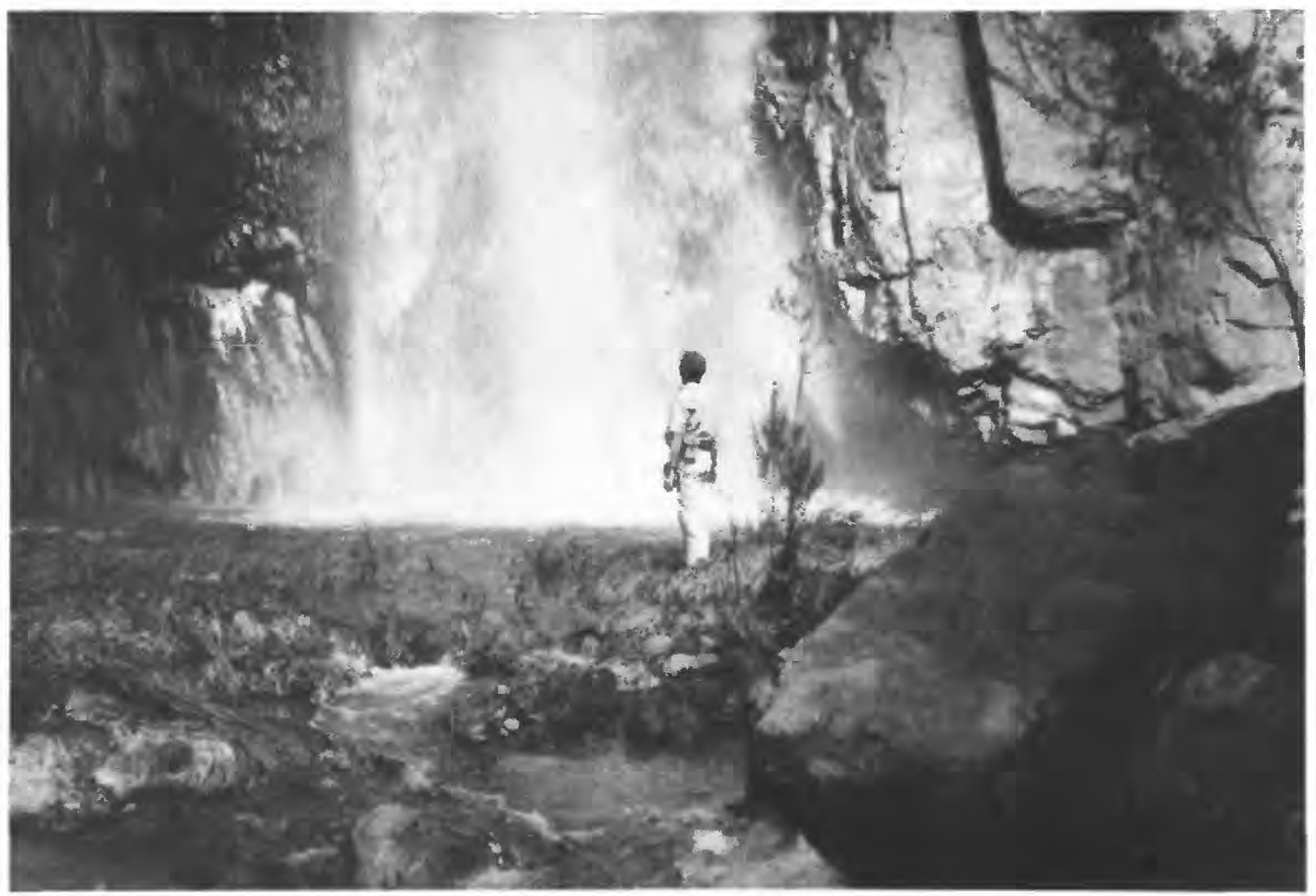

Figure 8. Cattail Falls. Record flow of about 5.0 cubic feet per second or about 2,250 gallons per minute is seen here June 25, 1986. Photograph by Paul M. Buszka. 
geochemical data for the water of Oak Spring (LopezSepulveda, 1984).

\section{Acknowledgments}

The authors acknowledge numerous officials and other employees of the National Park Service in Big Bend National Park: Superintendent David Dreier, former Superintendent Jim Carrico, Mike Fleming, Betty Alex, Tom Alex, Rudy Fichtner, Bob LaFrance, Duane Alire, Raymond Skiles, Charles Peterson, John Forsythe, Ken Grigsby, and Terry Meaders for their readiness to assist in field activities on short notice; and to Park Service officials William Werrell and Gary Rosenlieb of Fort Collins, Colorado, and Dr. Keith Yarborough of Santa Fe, New Mexico. Special gratitude is offered to Dr. Ross A. Maxwell for freely giving geologic information and for the inspiration he instills in fellow scientists by his very presence.

\section{HYDROGEOLOGY}

Insight into understanding the hydrogeology of The Basin and Oak Spring areas was acquired by integrating knowledge from all aspects of surface geology, drilling, seismic surveys, and Oak Spring flow characteristics. Collectively, these methods of investigation led to achieving many of the objectives of the study.

\section{Geology, Landforms, and Hydrologic Setting}

The present-day terrain of the Big Bend area is a product of a long and complicated geologic history. A wide variety of sedimentary, volcanic, and intrusive igneous rocks are exposed, and the configuration of most of the landforms reflect lithology and geologic structure.

The Chisos Mountains were formed by igneous intrusions in Tertiary time. Since then, erosion has carved out a rugged landscape of high peaks, ridges, deep narrow canyons, and broad depressions. This activity has exposed bedrock ranging in age from Late Cretaceous to Miocene. Erosional material in the form of Quaternary alluvium and colluvium blanket the bedrock in places (fig. 9). Stream channels or arroyos have developed, which convey surface runoff and occasional base flow, and some rock formations have become aquifers that furnish water to springs and to a few wells.
The Basin was created by the accelerated erosion of the softer Cretaceous strata elevated by the igneous intrusion. Where stream channels cross the geologic contact between the hard igneous rocks and the softer sedimentary rocks in upper Oak Creek, intermittent streamflow has eroded the sediments to a near vertical surface. Spectacular waterfalls are seen at these sites during periods of surface-water flow. Most notable of these is at The Window, where a deep notch is cut into the hard intrusive rock between Ward Mountain and Vernon Bailey Peak at the western end of The Basin. Here, Window Pouroff, a vertical drop of about $150 \mathrm{ft}$, marks the contact of the intrusive rock with the softer Eocene volcanic bedrock below. All of the surface runoff and spring flow in the $7.8-\mathrm{mi}^{2}$ watershed of The Basin that is not lost to evapotranspiration during its journey toward The Window flows over Window Pouroff.

Oak Creek continues at a much lower elevation westward from The Window. This lower Oak Creek area is an important part of the overall study area because Oak Spring issues from a steep bank of the creek less than one-half mile west of Window Pouroff. The lower Oak Creek area is mostly covered with an assortment of Quaternary streambed deposits, alluvial fans, outwash gravel aprons, and colluvium that includes talus and cliff debris having dimensions as large as house-size boulders; in places, however, Tertiary igneous extrusive and intrusive rocks are exposed. Quaternary material rests mostly or entirely on Eocene volcanic beds of the Big Bend Park Group in the vicinity of Oak Spring, although some igneous rocks are exposed as colluvium near the spring.

Cattail Falls is another spectacular pouroff about one-half mile south of The Window. It is unusual, however, because its drainage basin of $2.2 \mathrm{mi}^{2}$ is almost entirely within the Ward Mountain igneous pluton, is topographically separated from The Basin, and is almost unaffected by human activities because of access only by hiking. A few springs have been reported near the pouroff, and a few more have been reported about $2 \mathrm{mi}$ up Cattail Canyon. Because of the relative inaccessibility of the canyon, the rock material from which the springs flow is not known. Saturated zones in jointed igneous rock probably exist in the watershed and might constitute an aquifer that supplies the canyon springs. The flow at Cattail Falls ranges widely; floods are erratic and flashy largely because of precipitation over the drainage basin. Nevertheless, 

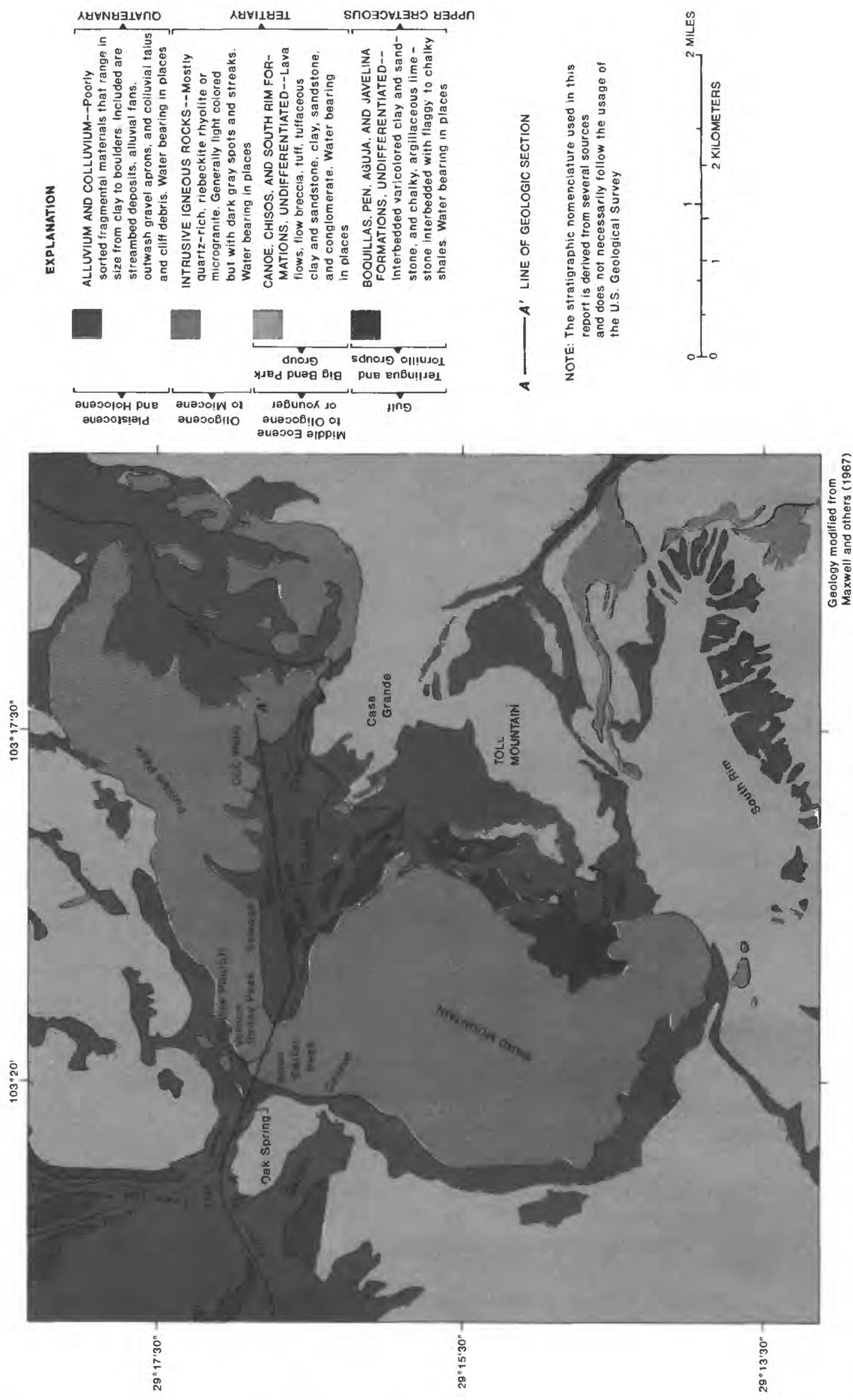

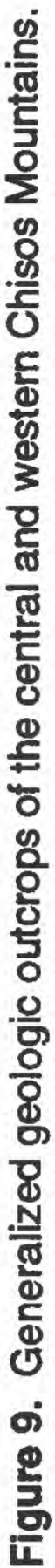


Cattail Falls is an important sampling point because of the pristine ecosystem associated with its watershed.

\section{Rock Formations and Hydrologic Significance}

A geologic section illustrating the subsurface relations among the Quaternary, Tertiary, and Upper Cretaceous rocks underlying a 3.1-mi reach of Oak Creek is shown in figure 10. The location of the section is shown in figure 9. The section shows that Quaternary alluvium and colluvium and thick Cretaceous strata underlie the sewage lagoons in The Basin and that hundreds of feet of Tertiary volcanic rocks and Cretaceous strata are in the subsurface near Oak Spring. The igneous intrusion at Window Pouroff is shown disrupting the continuity of the geologic formations between The Basin and Oak Spring areas.

\section{Upper Cretaceous}

The oldest outcropping rocks in the study area are those of the Upper Cretaceous Gulf Series. From oldest to youngest, these are the Boquillas and Pen Formations of the Terlingua Group and the Aguja and Javelina Formations of the Tornillo Group. Originating as marine and terrigenous sediments, these formations consist of chalky, argillaceous limestones interbedded with flaggy to chalky shales, calcareous clay with thin sandstone beds, medium-grained sandstone with interbedded yellowish-brown and maroon clay, and yellow, pink, and maroon bentonitic clay interbedded with a few poorly indurated, argillaceous sandstone layers. The aggregate thickness of the Upper Cretaceous strata, if undiminished by erosion, ranges from about 2,100 to $3,700 \mathrm{ft}$. Erosion and disruption by igneous intrusion within The Basin and Oak Spring areas have reduced the thickness of virtually all of these formations.

Although Upper Cretaceous strata are undifferentiated in figure 9, detailed mapping by Maxwell and others (1967) indicates that the Boquillas, Pen, and Aguja Formations crop out within The Basin in a few small areas. The major outcrops are north of Emory Peak to The Basin where the Boquillas (which contacts the igneous intrusion), Pen, and Aguja dip very steeply to the east and northeast at 20 to 85 degrees (Maxwell and others, 1967). Test drilling in 1987 for this study in the upper Oak Creek area of The Basin, together with isolated outcrops in this vicinity, indicate that the
Aguja probably underlies much of the fill material alluvium of Quaternary age along the east-west axis of The Basin.

The Javelina Formation, which does not crop out in The Basin, is the nearest Cretaceous formation to Oak Spring. It crops out about half a mile west of the spring and dips steeply toward the spring and toward the igneous intrusion forming Ward Mountain and Vernon Bailey Peak. The depth to the top of the Javelina and to the top of the Cretaceous near Oak Spring is estimated to be about $500 \mathrm{ft}$ on the basis of mapping done by Maxwell and others (1967).

Confining beds and aquifers are associated with the Upper Cretaceous strata. Some sand and sandstone beds are known to be aquifers at places in Big Bend National Park, and within the study area there is some evidence that they might be important sources of water. The preponderance of clay, shale, and other poorly permeable strata indicates that confining beds of Cretaceous age are widespread in The Basin.

\section{Tertiary Nonintrusive}

Tertiary nonintrusive rocks in and near the study area of Big Bend National Park are designated as the Big Bend Park Group. The Big Bend Park Group comprises the Canoe, Chisos, and South Rim Formations of Middle Eocene to Oligocene or younger age. These volcanic and sedimentary formations, which are undifferentiated in figure 9, consist of massive conglomerate, sandstone, clay, tuffaceous clay and sandstone, tuff, flow breccia, and lava flows. Sandstone and conglomerate are predominant near the base of the group, and pyroclastic beds and lava flows become predominant toward the top. The aggregate thickness of these Tertiary rocks, where uneroded, ranges from about 3,500 to 5,500 ft (Maxwell and others, 1967).

Tertiary volcanic and sedimentary rocks are widespread in the Chisos Mountains because of their great thickness and resistance to erosion. They are most prominent at such landmarks as Casa Grande, Toll Mountain, Emory Peak, and South Rim. At Casa Grande, about $3,100 \mathrm{ft}$ of Tertiary nonintrusive rocks overlie the Cretaceous strata. In a large part of The Basin, and especially along much of the reach of upper Oak Creek where extensive alluvium and colluvium overlie probable Cretaceous bedrock, most of the thick Tertiary volcanic and sedimentary rocks have been totally eroded. However, in the Oak Spring area where these Tertiary rocks dip from 5 to 20 degrees east and 


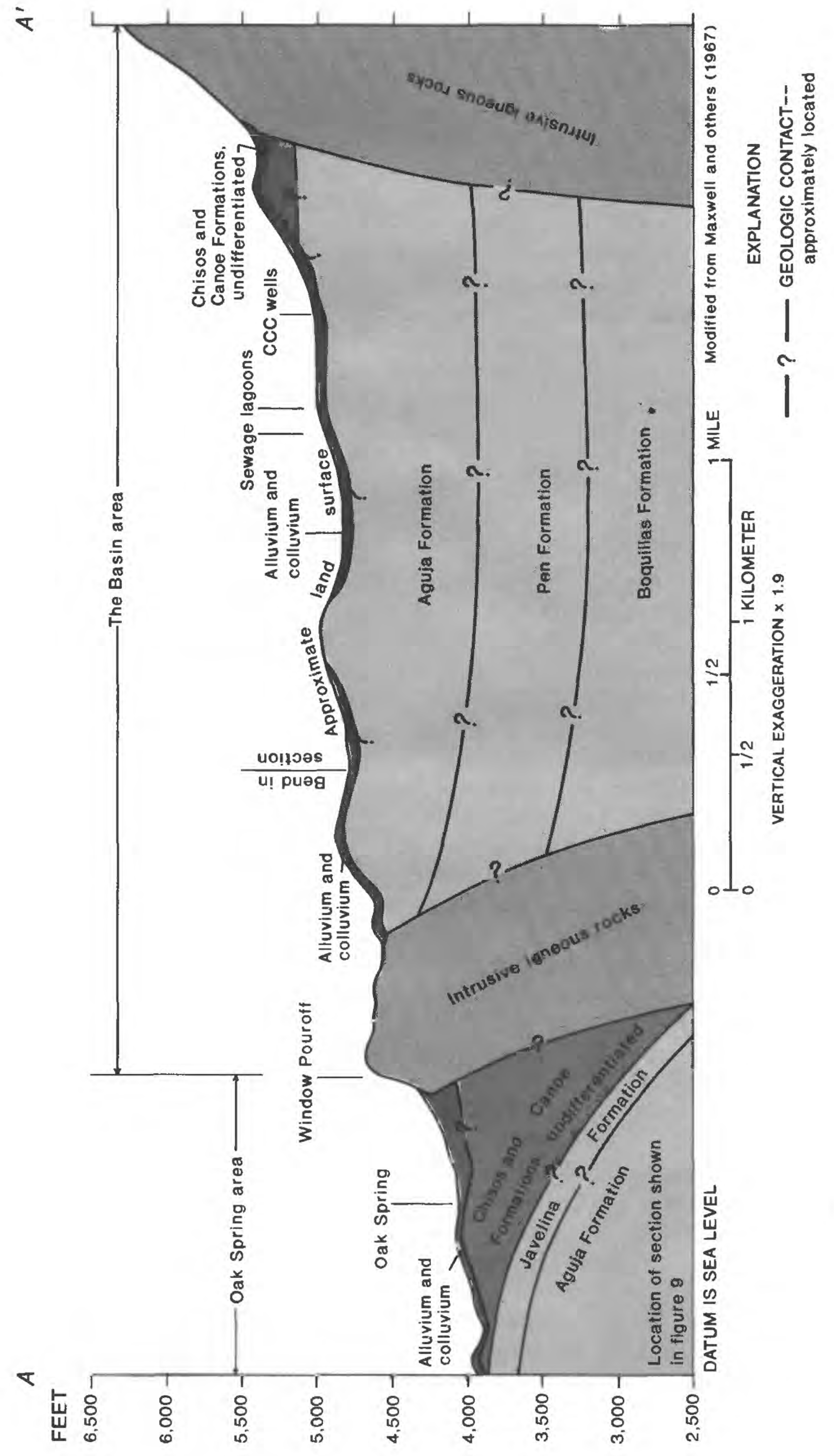

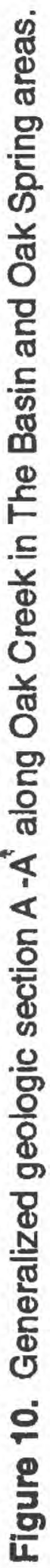


southeast toward the igneous pluton, they are presumed to extend from near the land surface to an estimated depth of $500 \mathrm{ft}$ near Oak Spring, on the basis of mapping by Maxwell and others (1967). Downcutting by lower Oak Creek has cut a deep channel through $100 \mathrm{ft}$ or more of the thick volcanic rocks, which are covered in some places along both banks of the channel by a mantle of Quaternary alluvium with large boulders of cliff debris and smaller talus material.

Sand and sandstone beds at shallow levels in the bedrock formation beneath Quaternary alluvium have been shown by test drilling to be water-bearing. Data presented in this report imply that a sand bed about 5$\mathrm{ft}$ thick and 75- $\mathrm{ft}$ deep near Oak Spring is the aquifer discharging to Oak Spring. The formation containing the sand bed might be the Chisos Formation of Tertiary age as mapped in the area by Maxwell and others (1967), although lithologically, it bears some resemblance to the Aguja Formation of Cretaceous age. This aquifer that supplies water to Oak Spring is termed the "Oak Spring aquifer."

\section{Tertiary Intrusive}

The intrusive igneous rocks in Big Bend National Park are most evident within the Chisos Mountains. Here, the exposed thickness of intrusive rocks reaches 1,500 to $2,500 \mathrm{ft}$ and is topographically expressed by very steep slopes and sheer cliffs. Ward Mountain, Amon Carter Peak, Vernon Bailey Peak, and Pulliam Peak form a crescent or arc bordering The Basin on the west and north. These prominences are former cupolas that are now manifestations of the parent Chisos Mountains pluton.

The intrusive igneous rocks are mostly quartzrich riebeckite rhyolite or microgranite. Rock-forming oxides of aluminum, ferric iron, potassium, and sodium are present in amounts ranging from 5 to 16 percent (Maxwell and others, 1967); thorium and uranium are present in trace amounts (Gottfried and others, 1962), as is the mineral fluorite. The rocks are light colored on fresh exposure but could have dark gray spots and streaks. Their weathered surface imparts a light reddish-brown appearance. According to Maxwell and others (1967), the magma probably crystallized at less than a few thousand feet below the original land surface at the time of intrusion. The intrusive igneous rocks are believed to be water-bearing in places on the basis of data in this report.
The emplacement of the Chisos Mountains pluton affects the hydrogeologic framework of The Basin. Although rocks forming the pluton probably came from the same magmatic source, several separate intrusions comprise the pluton. The intrusions, which occurred in Oligocene time with activity extending into Miocene time (Maxwell and others, 1967; Busbey and others, 1986), were generally emplaced at an angle from the southeast into the older Cretaceous and Tertiary rocks. This orientation of the pluton might be seen by the direction and degree of dip of the older rocks near the intrusive contact, and in the intrusive igneous rock at the top of Window Pouroff by jointing that dips toward the southeast. Within The Basin, the older rocks, where visible on the southwest side of The Basin, dip steeply away from the observable sides of the crescent-shaped rim of the pluton, creating a possible syncline or trough. Talus on the north side of The Basin covers the contact of the older intruded rock with the pluton. Maxwell and others (1967) state that the character of beds in a nearby exposure of Aguja Formation indicates that the formation ends abruptly against the pluton. At the frontal (northwestern) edge of the pluton in the Oak Spring area, the dip of the Cretaceous and Tertiary strata is steeply toward the pluton.

The intrusive igneous rock might form a barrier to both westerly and easterly ground-water flow.

Because the pluton is continuous to great depth beneath its crescent-shaped outcrop, the intrusive rock, which generally has very small permeability, but could have larger permeability in some areas, might function as a barrier to ground-water flow to the west, at least in the Quaternary fill deposits. A possible easterly flow out of The Basin could occur, however, in the underlying older Cretaceous rocks, which have an easterly component of dip.

Although a part of the total ground-water resource within The Basin might be restricted in its flow, some ground water from Quaternary and possibly older rocks discharges at the land surface to form a spring at The Window where the Quaternary waterbearing strata gradually thin to zero. Ground water that is forced to the surface at this point flows over Window Pouroff onto alluvium and colluvium and underlying bedrock in lower Oak Creek.

\section{Quaternary}

Alluvium and colluvium of Pleistocene and Holocene age cover most of the lower elevations in The 
Basin for a considerable distance on either side of upper Oak Creek. In the lower Oak Creek area these sediments obscure part of the bedrock for a considerable distance on either side of the arroyo, especially north of the arroyo to the next smaller creek. The alluvium and colluvium consist of fragmental material that ranges in size from clay to house-size blocks or boulders. Various types of these Quatemary fill deposits, represented here as alluvium, are the common streambed deposits, alluvial fans, and outwash gravel aprons. Colluvium is in the form of talus and cliff debris and could appear as house-size blocks or boulders. Much of the fragmental material incorporated into these deposits is poorly sorted, with very fine sediment closely associated with large fragments or boulders; little or no horizontal stratification is present. This heterogeneity is most noticeable along the channel of upper Oak Creek (fig. 11).

In The Basin, the composition and thickness of alluvium and colluvium in the vicinity of the sewage lagoons in upper Oak Creek were determined by test drilling during the study. Here, along a channel of Oak Creek, the alluvial and colluvial fill material is about 20 to $50 \mathrm{ft}$ thick. Composition of the fill material is similar to nearby intrusive and volcanic rocks, which underwent extensive erosion in Quaternary time. Ground water was not encountered in the alluvium and colluvium where the test drilling occurred; thus, the fill material is unsaturated in at least a part of its extent in upper Oak Creek. However, evidence of possible saturation in the fill material in other areas of The Basin is indicated by water in the upper and lower CCC wells east of the lagoons. These wells are assumed to have fully penetrated the shallow fill material in and near a channel of upper Oak Creek. However, the wells could have tapped an Aguja aquifer beneath unsaturated fill material. Also, as previously mentioned, the flow from Window Spring at the western end of The Basin is issuing from alluvium and colluvium at places where the water table intersects the land surface. This occurs near the point where fill material in the channel thins to zero as the stream crosses the underlying igneous intrusive rock. Window Spring is therefore, a seepage or contact spring that migrates upslope or downslope depending upon the elevation of the water table at any one time. The zone of spring migration within the fill material is at least $450 \mathrm{ft}$ long, the upslope end of which is associated with periods of high precipitation and accompanying high water tables. For those areas of saturated alluvium and colluvium in The Basin, the term "The Basin aquifer" is hereby applied.

In the Oak Spring area, test drilling has shown that most of the ridge just north of Oak Canyon (fig. 9) is a boulder field where large boulders with dimensions up to several tens of feet overlie probable Tertiary bedrock. The boulders are riebeckite rhyolite blocks that came from the igneous intrusive mountains to the east and were deposited by gravitational falling, rolling, and sliding assisted by possibly catastrophic flooding through The Window. Test drilling and numerous seismic surveys conducted in this area show the thickness of the fragmented rhyolite mass to range from almost $40 \mathrm{ft}$ near Oak Spring to more than $100 \mathrm{ft}$, with thickness increasing eastward.

\section{Drilling}

Test drilling was vital in supplying hydrogeological data in critical places. Site-specific hydrogeological information was collected from the test borings. This section describes the drilling technique used and presents and interprets data from sites in The Basin and in the Oak Spring area.

\section{Techniques}

An Odex 115 drilling system mounted on a truck was used in the drilling program in The Basin. It successfully drilled the test holes and cased the monitoring wells in unconsolidated alluvial material. The technique uses air as a drilling medium when penetrating unsaturated and saturated alluvium to eliminate the introduction of foreign drilling fluids. With this method, steel casing is allowed to advance down the hole as the drilling progresses.

As described by Hammermeister and others (1985), the method uses a down-hole percussion hammer to drill and ream just ahead of the bottom of the advancing casing. A pilot bit, in conjunction with an eccentric reamer, drills a hole slightly larger than the outside diameter of the casing. The hole diameter is 5.91 in. whereas the outside diameter of the casing is $5.51 \mathrm{in}$. The percussion hammer also impacts on the casing by means of a shoe attached to the bottom joint of the casing. This action causes the casing to advance downward as drilling progresses. If saturation is encountered, the drill cuttings and formation water are returned to land surface through the inside of the cas- 


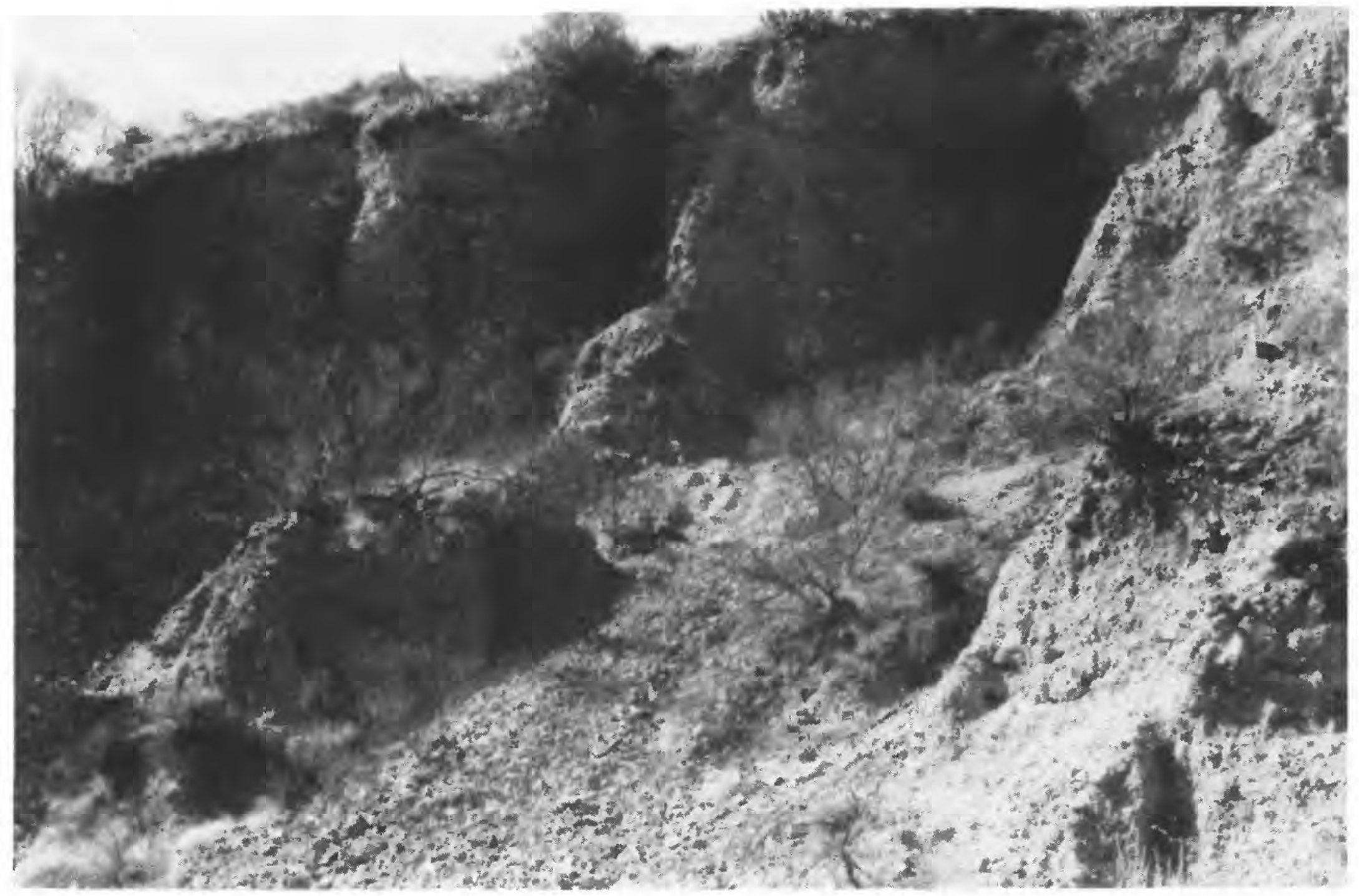

Figure 11. Alluvium and colluvium in a high bank of a channel of upper Oak Creek. The 20 feet of material shown here is underlain by possibly 30 feet of additional fill material upon bedrock that is possibly Cretaceous Aguja Formation. Photograph by E.T. Baker, Jr. 
ing. This minimizes the disturbance of the borehole wall from abrasion by cuttings or water.

The Odex 115 drilling system was utilized in the above-described manner to drill through the bouldery, alluvial deposits in upper Oak Creek. The method of casing the holes, however, did not utilize the steel casing as the permanent casing for the wells. Instead, polyvinylchloride (PVC) tubing equipped with a screen was set inside the steel casing to the bottom of the hole, and the casing was pulled out after the well was completed. In this manner, caving of the hole was prevented prior to installation of the PVC casing.

A drilling rig mounted on skids was used in the drilling program in the Oak Spring area. The equipment was transported into the area and from site to site by helicopter. ${ }^{1}$ The holes were cored with a diamond core barrel used in conjunction with a casing advancer. With this drilling method, as with the Odex 115 drilling system, steel casing is allowed to advance down the hole in increments behind the coring operation. This method uses rotary action to drill and can use a variety of drilling fluids. The coring and reaming are done in alternating steps, using a wire-line core barrel with nominal 3-in. outside diameter working inside and below the advancing steel casing with 3-1/2-in. outside diameter. After each coring run, the casing-advancer bit is emplaced at the bottom of the casing and the hole is then reamed to the bottom of the core hole. By this means the casing follows the bit to the bottom, after which the bit is removed from the hole. The casing thus eliminates any caving of the hole and prevents contamination of the core from up-hole fragments.

The drilling method used in the Oak Spring area provided good results. Highiy fractured rhyolite boulders just below the surface in the Oak Spring area were cored without the problem of loose fragments caving into the open hole. Water from Oak Spring was used in the operation as a drilling medium; from 10 to $15 \mathrm{gal} /$ min were allowed to flow down the hole to the bit principally for heat dissipation. The wells were temporarily cased with the steel casing, but this was removed after the PVC tubing and screen were in place.

\footnotetext{
1 The steep slopes of the area prohibit driving a drill rig to the sites. Access by land would have required a bulldozer to make a road in some places and to pull the rig up some slopes. Archeological sites have been identified in the general area and others could exist. To preserve the landscape and archeological resources, the Park Service denied land access.
}

\section{The Basin Area}

The two selected areas for obtaining hydrogeological information on possible aquifers supplying Oak Spring are The Basin and Oak Spring areas. Because of the lack of properly located existing wells or test borings, test drilling was vital in supplying hydrogeological data in critical places.

The Basin was drilled first because the sewage lagoons and other potential contamination sources are centered here. If the lagoons are not contaminating the ground water in The Basin, then the influence of possible leakage of the lagoons on Oak Spring is essentially insignificant or nonexistent.

Four boreholes (TB-1, TB-2, TB-3, and TB-4) were drilled in August 1987 near the lagoons in The Basin along upper Oak Creek (fig. 12). Three of the holes (TB-1, TB-2, and TB-3) were cased and completed for monitoring.

The borehole-construction methods and materials are as follows: Casing is nominal 2-in. PVC schedule 80 (1-7/8-in. inside diameter and 2-3/8-in. outside diameter); screen is mill-slotted PVC 10-ft long of the nominal size of the casing; well is gravel-packed opposite the screen with the top of the gravel pack sealed with one sack of bentonite in pellet form weighing $\mathbf{5 0}$ pounds; the hole is backfilled with cuttings; and a short section of 4-in. steel casing is set and cemented in the hole over the PVC casing for surface protection. The steel casing sticks up 2 to $3 \mathrm{ft}$ above the land surface and has a hinged cap and lock.

TB-1 is $945 \mathrm{ft}$ west (down-creek) from the lower $\mathrm{CCC}$ well, about $300 \mathrm{ft}$ east of the small (upper) lagoon, and $66 \mathrm{ft}$ north of a main upper Oak Creek channel. The boring depth is $46 \mathrm{ft}$ with the bottom $5 \mathrm{ft}$ in red clay (possibly Aguja bedrock). The alluvium and colluvium from the land surface to $41 \mathrm{ft}$ and the $5 \mathrm{ft}$ of red clay were dry, and the boring was dry when cased and completed August 6, 1987, and dry when last measured March 30, 1988.

TB-2 is at the western end of the large (lower) lagoon, $9 \mathrm{ft}$ from the exterior base of the lagoon levee, and $58 \mathrm{ft}$ north of a main upper Oak Creek channel. The boring depth is $56 \mathrm{ft}$ with the bottom 23 to $24 \mathrm{ft}$ in mostly red clay (possibly Aguja bedrock). The alluvium and colluvium from the land surface to 32 to $33 \mathrm{ft}$ and the 23 to $24 \mathrm{ft}$ of mostly red clay were dry, and no moisture was encountered. The boring was dry when cased and completed August 12, 1987, and dry when last measured March 30, 1988. 


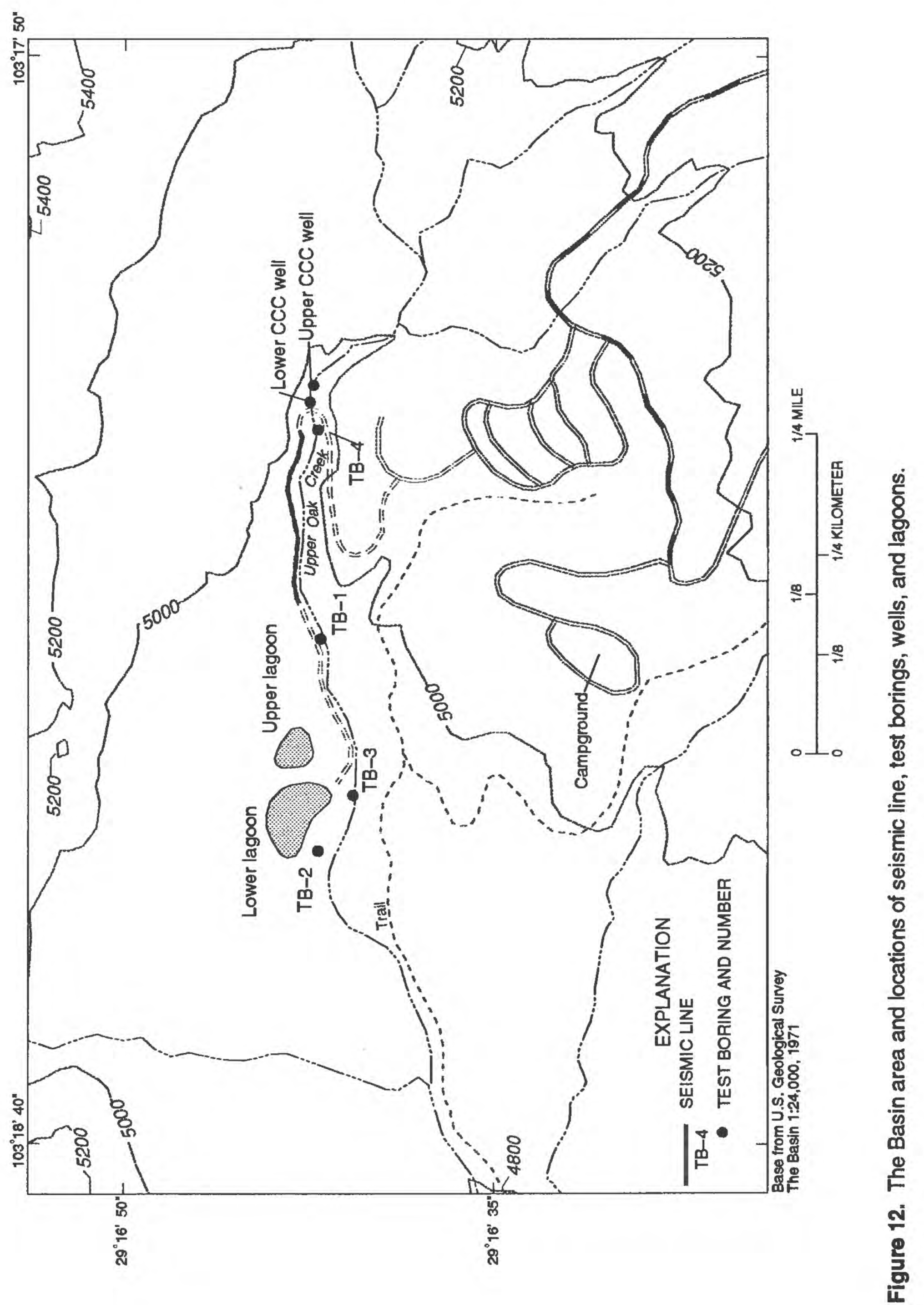


TB-3 is in a main channel of upper Oak Creek $280 \mathrm{ft}$ up-creek (east) of TB-2 and southwest of the east end of the large lagoon (fig. 13). The boring depth is 44 $\mathrm{ft}$ with the bottom $2 \mathrm{ft}$ in red clay (possibly Aguja bedrock). Some minor moisture, but no saturation, was encountered in the alluvium and colluvium and in the red clay. The boring was dry when cased and completed August 13, 1987, and dry when last measured March 30, 1988.

TB-4 was not completed as a monitoring site; it was drilled August 14, 1987, in a main channel of upper Oak Creek $125 \mathrm{ft}$ down-creek (west) of the lower CCC well. The depth of the boring is $27 \mathrm{ft}$, and the surface of the red clay bedrock (possibly Aguja) is believed to be at a depth of from 21 to $26 \mathrm{ft}$. The alluvium and colluvium down to $21 \mathrm{ft}$ was very moist in places, but no free water was detected.

The drilling results were unexpected because no free water was detected in the alluvium and colluvium at the drill sites. A shallow alluvial/colluvial aquifer had been assumed to exist and might have been receiving seepage outflow from the sewage lagoons. The assumption of the existence of a shallow alluvial/colluvial aquifer was based on the presence of ground water in the lower CCC well. Here, the water level in the well, which is about $30 \mathrm{ft}$ deep and generally has about 15 to $18 \mathrm{ft}$ of water in it, might represent the water table in what was assumed to be an alluvial/colluvial aquifer at that site. However, the well might have tapped an Aguja aquifer beneath the alluvium and colluvium, and the water level could represent a pressure head in the Aguja. If this is the case, then the fill material in the upper reaches of upper Oak Creek could be dry, and saturation would first occur at some point in the lower reaches of upper Oak Creek west of the sewage lagoons. This hypothesis presupposes that the eastwest reach of Oak Creek channel near the lagoons is at or near the deepest parts of the alluvial/colluvial trough.

A second hypothesis is that some ground water might be flowing in the alluvium and colluvium throughout most of The Basin but restricted to those places where the fill material is deepest. This hypothesis presupposes that the lagoons and a main channel of upper Oak Creek adjacent to the lagoons are on the north flank of the alluvial/colluvial trough, the eastwest axis of which is more centrally located in The Basin.

A third hypothesis is that any saturated flow near the lagoons (and near the lower CCC well) is restricted to paleochannels in the bedrock (Aguja) surface. Using this hypothesis, the drilling data would be interpreted to imply that the lower CCC well is in a paleochannel (local bedrock low). TB-4 could be near the margins of paleochannels and saturated only following storm events. TB-1, TB-2, and TB-3 could be on local bedrock (Aguja) highs. In this case contamination from the lagoons could be flowing into The Basin aquifer through local paleochannels that were not intercepted by the test borings.

A fourth hypothesis is that any leakage from the lagoons is moving down into bedrock aquifers. In this case the leakage would have to penetrate the red clay bedrock (a confining layer) beneath the alluvial/colluvial fill.

The most likely hypothesis is the initial one stated. This hypothesis infers from geomorphological principles that the present Oak Creek channel near the lagoons is at or near the deepest parts of the alluvial/ colluvial trough.

Results of the drilling program in The Basin indicate that the alluvium and colluvium along that part of upper Oak Creek at and near the lagoons is not saturated and that a shallow alluvial/colluvial aquifer does not exist in this immediate area. Some of the deepest alluvial and colluvial fill material, believed to be in proximity to the axis of upper Oak Creek, was also assumed to be in the general area where the test drilling was concentrated, which enhanced the possibility of encountering an aquifer. It can be concluded that a reservoir of shallow ground water is not present everywhere in the fill material, and, therefore, much of The Basin alluvium and colluvium apparently does not and cannot contribute a large volume of ground water to the only surface outlet of The Basin--Window Pouroff. Because test borings TB-2 and TB-3 are adjacent to and downslope from the large sewage lagoon and encountered no saturation and little or no moisture, substantial leakage is not believed to be occurring, and, therefore, a pollution plume was not identified. In the unlikely event that some leakage is occurring and that the contaminant plumes are developing, such pollution would be restricted to paleochannels not intercepted by the test borings.

\section{Oak Spring Area}

Three test borings (TB-5, TB-6, and TB-7) were drilled in August 1989 in the Oak Spring area near lower Oak Creek (fig. 14) to locate the aquifer supply- 


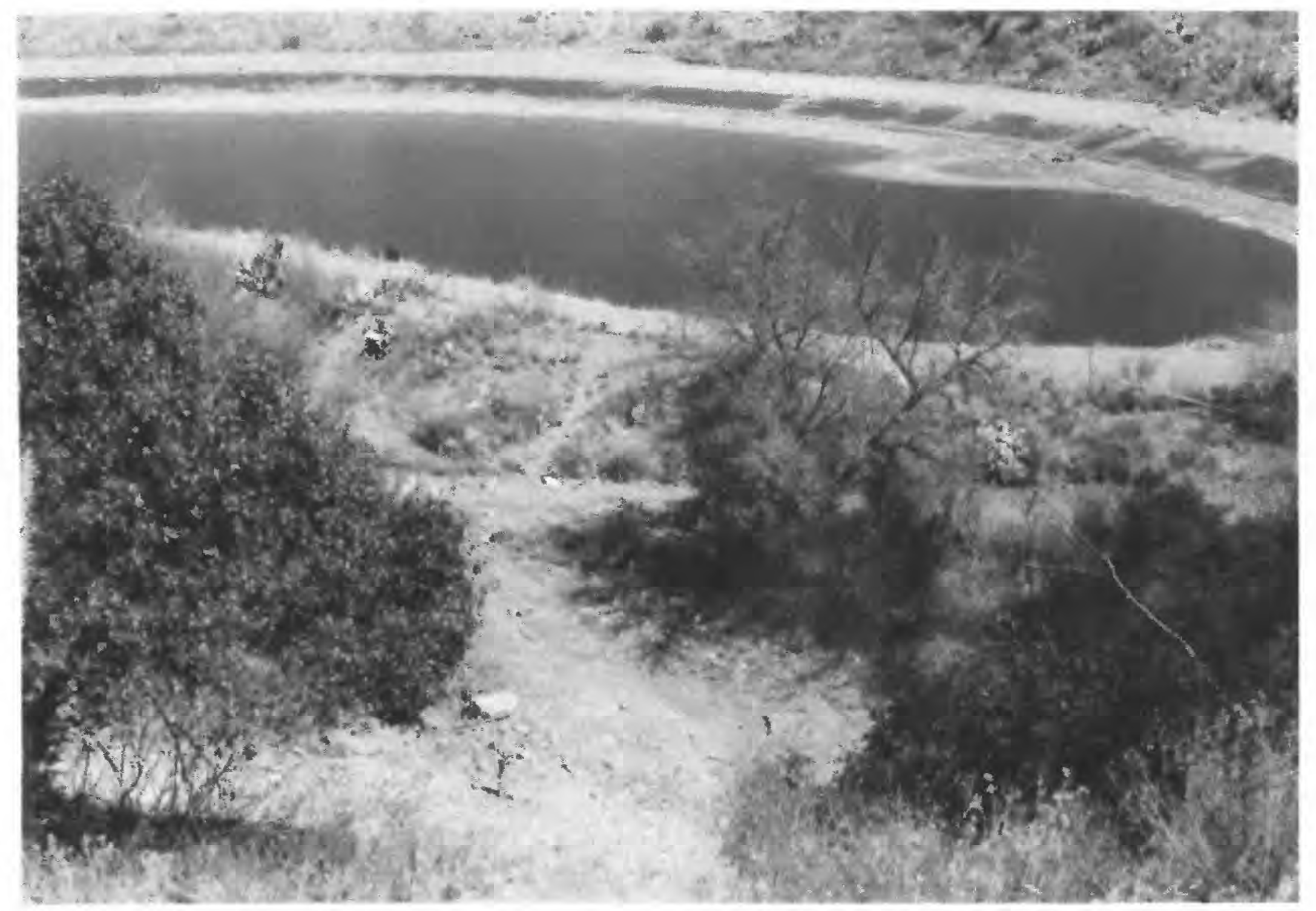

Figure 13. Test boring TB-3 near lower sewage lagoon. Test boring well is in main upper Oak Creek channel and 75 feet south of top of lagoon levee. Photograph by E.T. Baker, Jr. 


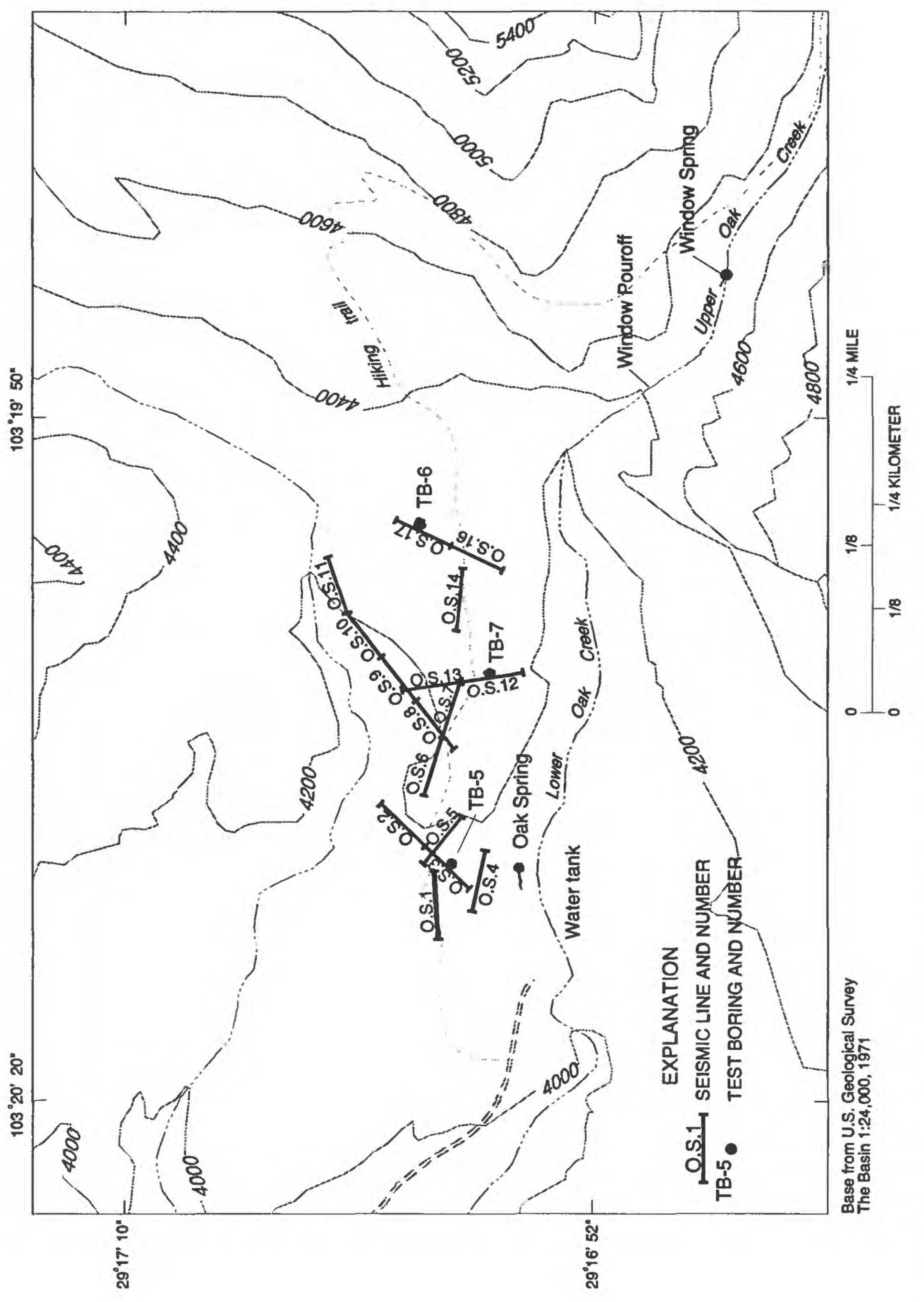

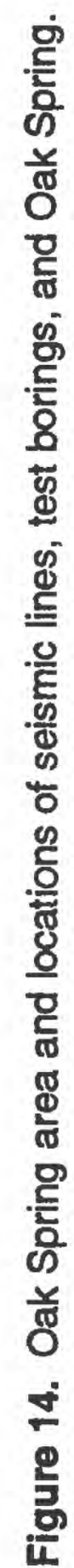


ing water to Oak Spring and to determine, if possible, the aquifer's recharge zone. Two of the borings (TB-5 and TB-7) were converted to monitoring wells.

Detailed descriptions of the cores from the three boreholes are given in table 1 (at end of report).

The well-construction methods and materials are as follows: Casing is nominal 2-in. PVC schedule 80 (1-7/8-in. inside diameter and 2-3/8-in. outside diameter); screen is mill-slotted PVC of the nominal size of the casing and encompasses the depth interval of the water sands; well is gravel-packed opposite the screen; and the top of the gravel pack is sealed with bentonite in pellet form. At the surface, a 4-in.-diameter steel casing having a 2 -ft stickup and a 2 -ft subsurface extension is cemented in the hole over the PVC casing and is fitted with a cap and lock.

TB-5 was the first test boring in the Oak Spring area. Completed August 10, 1989, the hole was purposely drilled close to Oak Spring to increase the chance of locating the aquifer. The boring was drilled $280 \mathrm{ft}$ north of the spring at a level of $85 \mathrm{ft}$ above the outlet of the spring. The total depth of the boring is $117.6 \mathrm{ft}$. After passing through $29 \mathrm{ft}$ of highly fractured rhyolite boulders at $39 \mathrm{ft}$, the core hole penetrated about $79 \mathrm{ft}$ of mostly mottled, smooth, compact clay with a few relatively thin, but significant, sandstone beds. One 5-ft-thick bed of what is believed to be loose sand, which could not be recovered as a core because it lacked induration, is the aquifer supplying water to Oak Spring. Occurring at 75 to $80 \mathrm{ft}$ below land surface, the bed is roughly at the level of the emergence of Oak Spring in the steep bank of Oak Canyon. The waterstage recorder at Oak Spring picked up the effects of drilling through the aquifer by showing a small but definite increase in stage of $0.03 \mathrm{ft}$, which represents an increase in spring flow of $6.5 \mathrm{gal} / \mathrm{min}$. This increase is attributable to the 10 to $15 \mathrm{gal} / \mathrm{min}$ of water from the coring operation that recharged the aquifer and increased the hydraulic pressure.

TB- 6 was the second test boring in the Oak Spring area. This hole, drilled August 16, 1989, is $1,450 \mathrm{ft}$ east-northeast of Oak Spring at a level of 188 $\mathrm{ft}$ above the outlet of the spring. It is the closest boring to the igneous intrusives that form the northwestern edge of the Chisos Mountains. The hole penetrated fractured rhyolite boulders from near the land surface to a total depth of $100.5 \mathrm{ft}$. An 18-ft-deep cavity was detected below the bottom of the core hole. Circulation was being lost almost continuously during the coring. The test boring, as well as the deep cavity below the bottom, was unsaturated to its total depth. Several applications of cement were required to consolidate the loose rhyolite fragments and to attempt to prevent the loss of circulation. Consequently, the rate of penetration was much slower than normal. A 3-in. rock bit was twisted off in the hole, and the hole had to be abandoned about $100 \mathrm{ft}$ short of the intended depth.

TB-7 was the third test boring in the Oak Spring area and was selected to avoid the thickness of rhyolite boulders encountered at the site of TB-6. TB-7, completed August 26, 1989, is $775 \mathrm{ft}$ east of Oak Spring at a level of $146 \mathrm{ft}$ above the outlet of the spring. The boring reached a depth of $184.5 \mathrm{ft}$. After penetrating $75 \mathrm{ft}$ of fractured rhyolite boulders with clay interfillings, the borehole penetrated about $110 \mathrm{ft}$ of mostly maroon clay with three relatively thin sandstone beds. Very steeply dipping bedding planes (about 45 degrees) were noted in places in the clay core, indicating possible disruption by faulting. The sandstone beds were loose-to-indurated, mostly fine grained, and were water-bearing. No effect on the flow of Oak Spring was observed during the drilling of any of these sandstone beds.

Initially, 10 drilling sites were planned for the Oak Spring area in a pattern designed to trace the Oak Spring aquifer eastward in the direction of its supposed recharge area. Available funding allowed for drilling only three test borings, which yielded important information. The recharge area was not conclusively determined because of complex geologic conditions in the subsurface. However, the determination of the location and lithology of the Oak Spring aquifer was an important finding. Heretofore, this was the subject of only speculation and uncertainty.

The subsurface relation of the three test holes to Oak Spring and to land-surface profiles along lower Oak Creek and along the ridgetop where the three test holes were drilled is shown in figure 15 . The level of the Oak Spring aquifer as shown in the log of TB-5 is within a few feet of the level of Oak Spring. The Oak Spring aquifer could not be positively identified in TB7 , but it could be any one of the three sandstone beds above or below the Oak Spring level. TB-6 did not reach the sandstone and clay formation, but the base of the rhyolite boulders in TB-6 is less than $20 \mathrm{ft}$ above the level of the Oak Creek channel nearby. Water levels in TB-5 and TB-7 are from 40 to $60 \mathrm{ft}$ above the level of Oak Creek adjacent to the wells, yet the channel normally is dry in the reach between the wells. The only water that appears in Oak Creek during base-flow conditions is in the reach from $400 \mathrm{ft}$ upgradient from TB- 


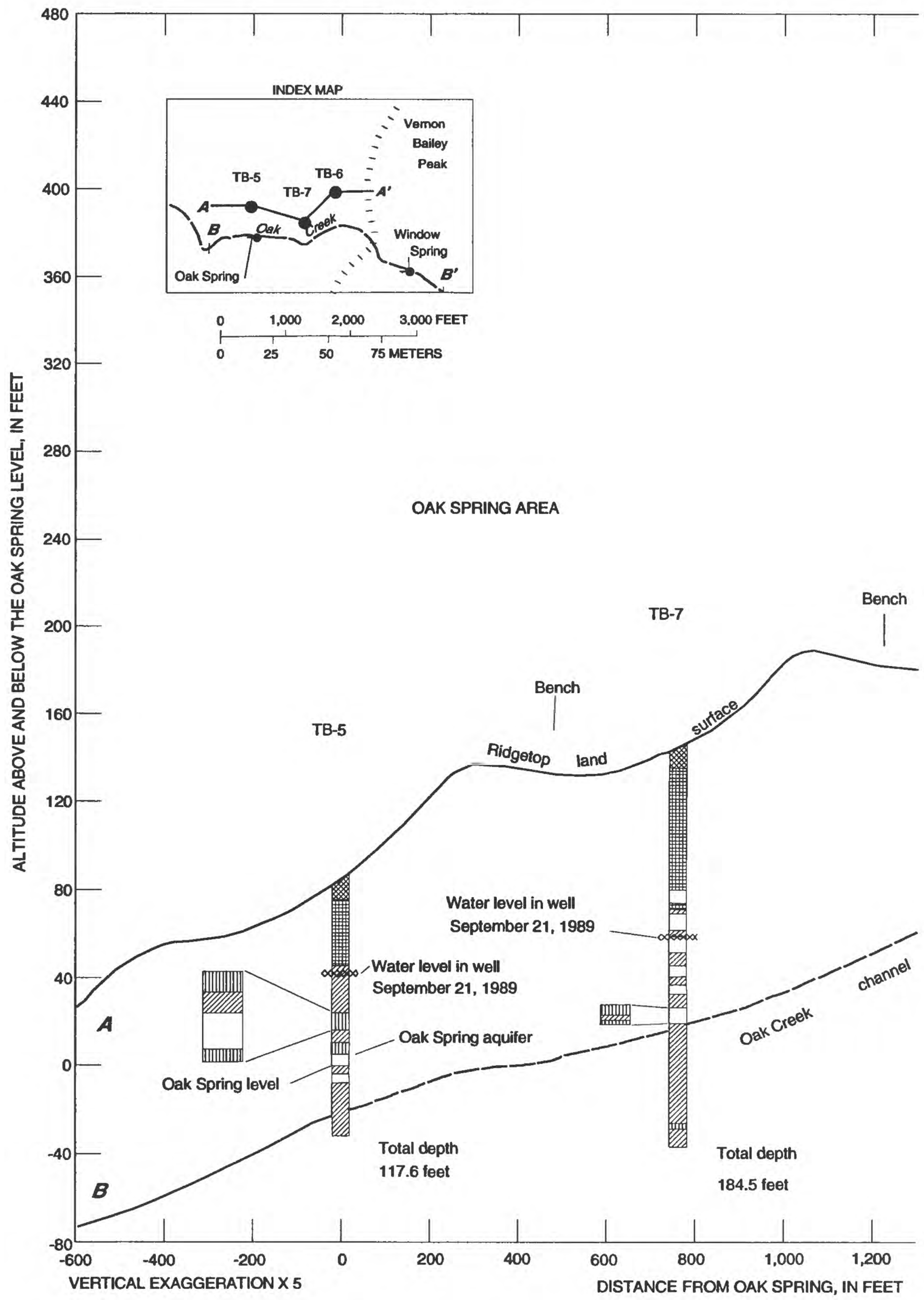

Figure 15. Profiles of the land surface and borehole logs showing relation to Oak Spring. 


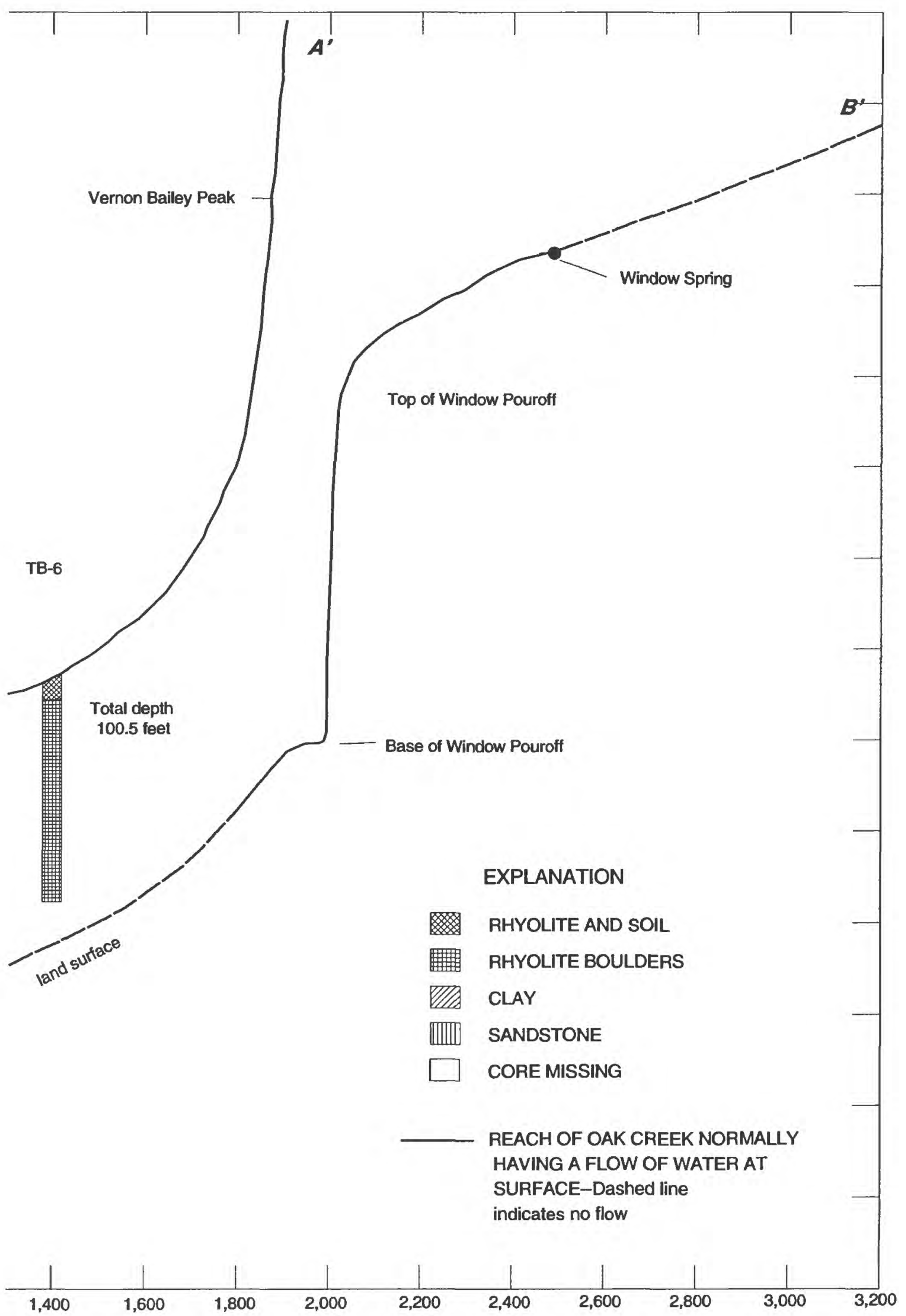


6 to Window Spring and downgradient from Oak Spring. Base flow downgradient from Oak Spring results entirely from the excess discharge of Oak Spring not utilized for public water supply.

As mentioned above, correlation of individual sandstone beds in TB-5 and TB-7 was not possible. Factors complicating an attempt at correlation were the obvious severe disruption of the beds by possible faulting and the absence of key marker beds. The sandstone and clay sequence in the test borings does not correspond well lithologically with the descriptions of the Chisos Formation--the formation mapped by Maxwell and others (1967) of the mountainsides immediately north and south of the Oak Spring area. However, the sandstone and clay sequence as seen in TB-5 and TB-7 does bear some lithological resemblance to observed exposures of the Upper Cretaceous Aguja Formation.

The general direction of ground-water movement in the Oak Spring aquifer probably is westward. Even though the sandstone supplying water to Oak Spring could not be positively identified in TB-7, it is possible that at least one of the three sandstone beds encountered in TB-7 is the Oak Spring aquifer as seen in TB-5. The higher water level in TB-7 to the east, compared with that in TB-5 to the west (fig. 15), strongly indicates a source (recharge) area in the higher elevations between TB-7 and Vemon Bailey Peak, an average distance of $1,500 \mathrm{ft}$ from Oak Spring.

A local deflection of the westerly ground-water movement toward the south (toward Oak Spring) is believed to be attributable to barriers caused by possible northerly-trending faults in the bedrock hidden beneath the alluvial and colluvial overburden. The location of these faults might coincide with the sharp vegetation changes to the east and west of Oak Spring, as seen in figure $7 \mathrm{~B}$.

\section{Seismic-Refraction Surveys By Dennis G. Woodward}

Seismic-refraction surveys were conducted prior to drilling test borings to assist in determining the subsurface hydrogeology for critical areas within the study area. The seismic-refraction technique has been effective in distinguishing and delineating the water table in unconsolidated sediments of various geologic origins. Conceptually, the alluvium in the study area overlies more consolidated bedrock; hence, a layering sequence of unsaturated alluvium overlying saturated alluvium overlying bedrock satisfies the condition that seismic velocity must increase with depth. Interpretive problems could arise in differentiating weathered bedrock, saturated alluvium, and thick caliche deposits in the alluvium, because in the subsurface all three deposits could have a similar seismic velocity.

\section{Seismic-Refraction Methods}

Seismic-refraction methods are based on the principle that the differences in the elastic properties of rocks result in changes in the velocity of wave propagation and changes in the geometry of the propagation path. The refraction method of seismic geophysics requires that two conditions be met in the subsurface horizons before depth to the various interfaces can be calculated accurately:

1. The seismic velocity of successive layers must increase with depth.

2. The various layers through which the refracted wave travels horizontally must have a thickness that permits transmission of the refracted wave. The minimum thickness is a function of the depth of burial and the velocity contrast between the adjacent layers.

The translation of seismic layers to geologic units is accomplished by comparing the seismic velocity of the layer in question to the published seismic velocity ranges for known geologic materials or formations.

Seismic-refraction data are collected in the field by recording the time for pulses of elastic energy to propagate through the subsurface from the point of initiation (the shot point) to the detectors (the geophones). In this study, a Nimbus Model ES-1210F 12-channel seismograph was used to collect and record the seismic data, and two different energy sources were used to generate the seismic energy. Initially, a Remington R21mm seismic electric 8-gauge shell with a 3-oz slug was used to generate the energy, but it soon became apparent that a larger energy source was required. Thus, the majority of the lines near Oak Spring were shot with Kinepak (a two-component explosive) detonated with a DuPont E-135 exploding bridgewire detector. The energy sources were fired at the bottom of boreholes drilled to about a 2-ft depth. Ideally, the Kinepak explosive would be placed at the bottom of a smooth-bored hole at a depth below the water table, 
backfilled with cuttings or dirt, and detonated. In the Oak Spring area, near-surface material consisted of a thin soil horizon ( 1 to 8 in.) covering rocks and boulders. The hand-held, portable power auger used to drill the shot holes was able to penetrate only the top 1 or 2 $\mathrm{ft}$ of the subsurface; consequently, the amount of explosives detonated at the base of the shot holes was more a function of preventing explosion craters in the landscape (and dangerous fiy rocks) than of obtaining optimal seismic records. The boreholes were backfilled with water to create a good acoustic couple with the subsurface.

In this study, the optimal field layout for determining the bedrock topography and lithologic changes was one in which the shot point was offset a distance so that near-surface velocity layers could be mapped as well as deeper layers. Each geophone spread recorded seismic data generated from at least two shot points. A shot point was offset, in-line, from each end of the geophone spread, thereby establishing a "forward" and a "reverse" shot point. By analyzing the combined data from the forward and reverse shots, the effects of a dipping subsurface layer can be documented. Horizontal distances between the geophones and the shot holes were measured with a cloth tape, horizontal angles were determined with a Brunton compass, and vertical distances were measured with a hand level and surveying rod.

\section{Previous Seismic Surveys}

Within the last 10 years, two seismic-refraction surveys were successfully used to determine the geometry and ground-water potential of alluvial fans and subfan bedrock within the park near the northeastern flank of the Chisos Mountains. Archer (1982) conducted a seismic-refraction study of the Green Gulch fan (fig. 16), and concluded that most of the seismicvelocity data indicated a three-layer earth model. Layer 1 had a mean velocity of $1,123 \mathrm{ft} / \mathrm{s}$ and corresponded to the surface layer of unsaturated, weathered alluvium; layer 2 had a mean velocity of $3,367 \mathrm{ft} / \mathrm{s}$ and corresponded to unsaturated, unweathered alluvium; and layer $3 \mathrm{had}$ a mean velocity of $9,784 \mathrm{ft} / \mathrm{s}$ and corresponded to bedrock. Archer speculated that at a few locations, the presence of saturated alluvium might have been detected (Archer, 1982, p. 43); but he generally concluded that the gravel (alluvium) contained no high-velocity bottom layer that would be indicative of water saturation and that, consequently, recharge to the lower bedrock aquifers through the gravel is modest in quantity and occurs rapidly (Archer, 1982, p. 98).

Monti (1984) conducted a seismic-refraction survey in alluvial fans near the park headquarters (fig. 16). The seismic-velocity data indicated that a three-layer earth model was an appropriate representation of the subsurface. The velocity range for layer 1 was 1,250 to $2,500 \mathrm{ft} / \mathrm{s}$, corresponding to weathered alluvium; velocities for layer 2 ranged from 2,000 to $5,500 \mathrm{ft} / \mathrm{s}$, corresponding to alluvium; and layer 3 corresponded to bedrock. Bedrock velocities between 5,500 and 10,000 $\mathrm{ft} / \mathrm{s}$ were interpreted to represent sedimentary bedrock (sandstone, siltstone, or shale) and bedrock velocities greater than $10,000 \mathrm{ft} / \mathrm{s}$ were interpreted to represent igneous rock. Monti interpreted seismic velocities in the alluvial layer that ranged from 4,000 to $5,500 \mathrm{ft} / \mathrm{s}$ to be indicative of saturated gravel and identified a few locations where the existence of ground water in the alluvium was possible (Monti, 1984, fig. 12). However, he concluded that the possible zones of saturated gravel were isolated pockets and did not indicate the presence of any substantial water-table aquifer (Monti, 1984, p. 40).

\section{Seismic Interpretation}

The interpretation of shallow seismic-refraction data seldom is simple and straightforward. The traveltime plot of first-break arrivals is the basis for interpreting refraction data, and different combinations of subsurface structure or layering can result in the same travel-time plot.

Seismic-refraction data were analyzed with a computer program originally developed for the U.S. Bureau of Mines by Scott and others (1972), and modified by Scott (1977). The computer technique involves a two-dimensional modeling process in which the delay-time method is used to obtain a first approximation of model layers, after which iterative ray-tracing methods are used to refine the model. The criterion for adjusting and refining the model is that the discrepancies between travel times obtained from the field measurements and those obtained from computer raytracing are minimized. The following basic assumptions apply to the modeling procedure used in the model program:

\section{Layers are continuous and extend from one end of the refraction line to the other.}

2. Layer velocity increases with layer depth. 


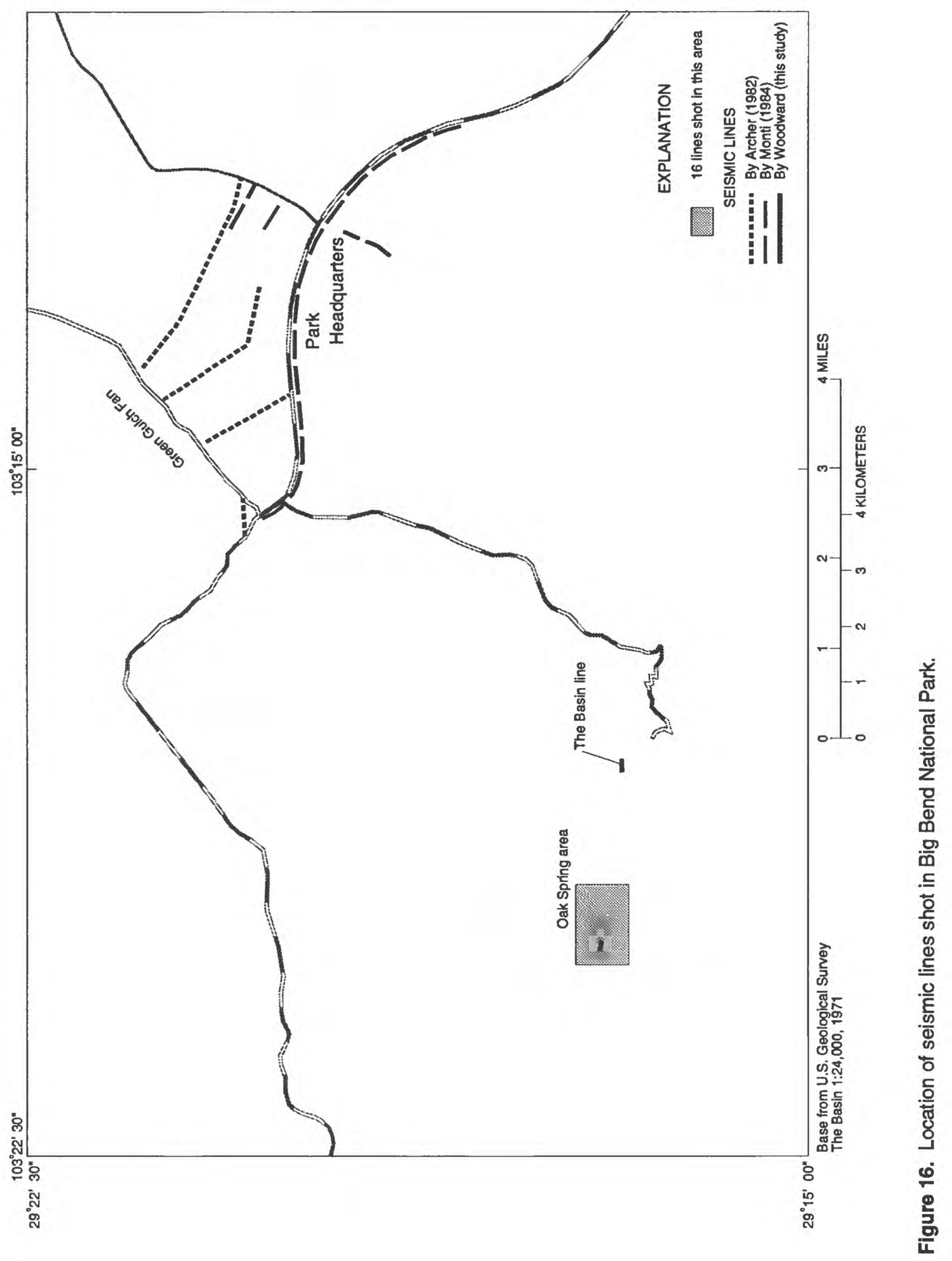


3. Horizontal velocity is equal to or greater than vertical velocity for any given layer.

4. Both horizontal and vertical velocities are constant within each layer from one end of the spread to the other.

The results of the model analysis for this study are depicted as depth profiles that show the land surface and the tops, thicknesses, and velocities of the interpreted velocity layers.

\section{The Basin Area}

The Basin line consists of three geophone spreads located on a service road that leads to the sewage lagoons (fig. 12). The line extends from about 150 $\mathrm{ft}$ east of 'TB-1 to about $90 \mathrm{ft}$ west of the lower CCC well encasement, a line distance of about $700 \mathrm{ft}$.

The line configuration was composed of three overlapping spreads, each spread consisting of 12 geophones set $20 \mathrm{ft}$ apart in a generally straight east-west line. The easternmost geophone of the westerly spread became the westernmost geophone of the next successive spread, thus providing overlapping coverage. Each spread was shot with four shot points in the manner previously described by having both near and far offset shots at each end of the line. There were $55 \mathrm{ft}$ of topographic relief in the line, with the westernmost shot point about $55 \mathrm{ft}$ lower than the easternmost shot point, which was $5 \mathrm{ft}$ west of the lower $\mathrm{CCC}$ well encasement.

The travel-time plot of first-break arrivals from The Basin line indicates that a three-layer earth model should be used for seismic interpretation. The velocities associated with the layers, and the range in depth to the top of each layer, are presented in table 2. Layer 1 (fig. 17) has an average velocity of about $1,550 \mathrm{ft} / \mathrm{s}$ and corresponds to unsaturated, weathered alluvium/colluvium. Layer 2 has an average velocity of about 2,750 $\mathrm{ft} / \mathrm{s}$, and is interpreted to correspond to an unsaturated alluvium/colluvium layer. The average velocity for saturated, unconsolidated material ranges from about 4,000 to about $6,000 \mathrm{ft} / \mathrm{s}$. Layer 3 has an average velocity of about $6,450 \mathrm{ft} / \mathrm{s}$ and is interpreted to correspond to bedrock. The interface between layers 2 and 3 represents the bedrock surface.

Interpretation of The Basin line indicates that the bedrock surface is fairly regular and slopes gently to the west. Depth to the bedrock surface ranges from about $58 \mathrm{ft}$ at the westem end of the line to about $35 \mathrm{ft}$ at the eastem end (fig. 17). TB-1, about $200 \mathrm{ft}$ west of the end of the line, encountered bedrock at a depth of about $41 \mathrm{ft}$. Although there was not a distinct indication of a saturated alluvial layer present--which was confirmed by test drilling west of the line--it is possible that a thin saturated layer could exist above the bedrock. The average velocity for saturated, unconsolidated material (about 4,000 to about $6,000 \mathrm{ft} / \mathrm{s}$ ) is close to the average velocity of the bedrock under the line (about $6,450 \mathrm{ft} / \mathrm{s}$ ). A saturated layer less than $10-\mathrm{ft}$ thick overlying the bedrock could exist and remain undetected by the survey.

\section{Oak Spring Area}

With respect to the seismic-refraction surveys, the Oak Spring area is on the uplands above lower Oak Creek immediately north and northeast of Oak Spring (figs. 3 and 7A). During December 1987 and March 1988, 16 refraction lines were shot in this area (fig. 14). The area lies within a recognized archaeological zone, and for reasons of archaeological integrity, the precise locations of each shot point were inspected in the field and approved by Park Service personnel. The lines were clustered in three groups, each group corresponding to a somewhat flat "bench" on the upland (figs. 14 and 15). Most of the easterly-westerly lines were located on an existing hiking trail to minimize the environmental impact of the survey, and the northeasterlysoutherly lines traversed the "benches." Lines O.S.1 and O.S.4 were located about 275 and $65 \mathrm{ft}$, respectively, north of the distinct "green band" of vegetation that brackets Oak Spring (fig. 7B).

All the seismic lines had the same basic configuration--shot points straddling a straight line of 12 geophones set $20 \mathrm{ft}$ apart. The shot offset is the distance between the shot point and the nearest geophone and, for most lines, ranged from 20 to $35 \mathrm{ft}$.

The travel-time plots of first-break arrivals on the Oak Spring lines indicate that a three-layer earth model should be used for seismic interpretation. The velocities associated with the layers, and the range in depth to the top of each layer, are presented in table 2. Although the velocity range varies across the area for each layer, table 3 shows that a larger range of velocities was encountered by Archer (1982) and Monti (1984) along similar alluvial fans located on the northem side of the Chisos Mountains (fig. 16).

The three boreholes drilled in the Oak Spring area were instrumental in assigning lithologic correlation to the velocity layers. Borehole TB-5 was drilled 

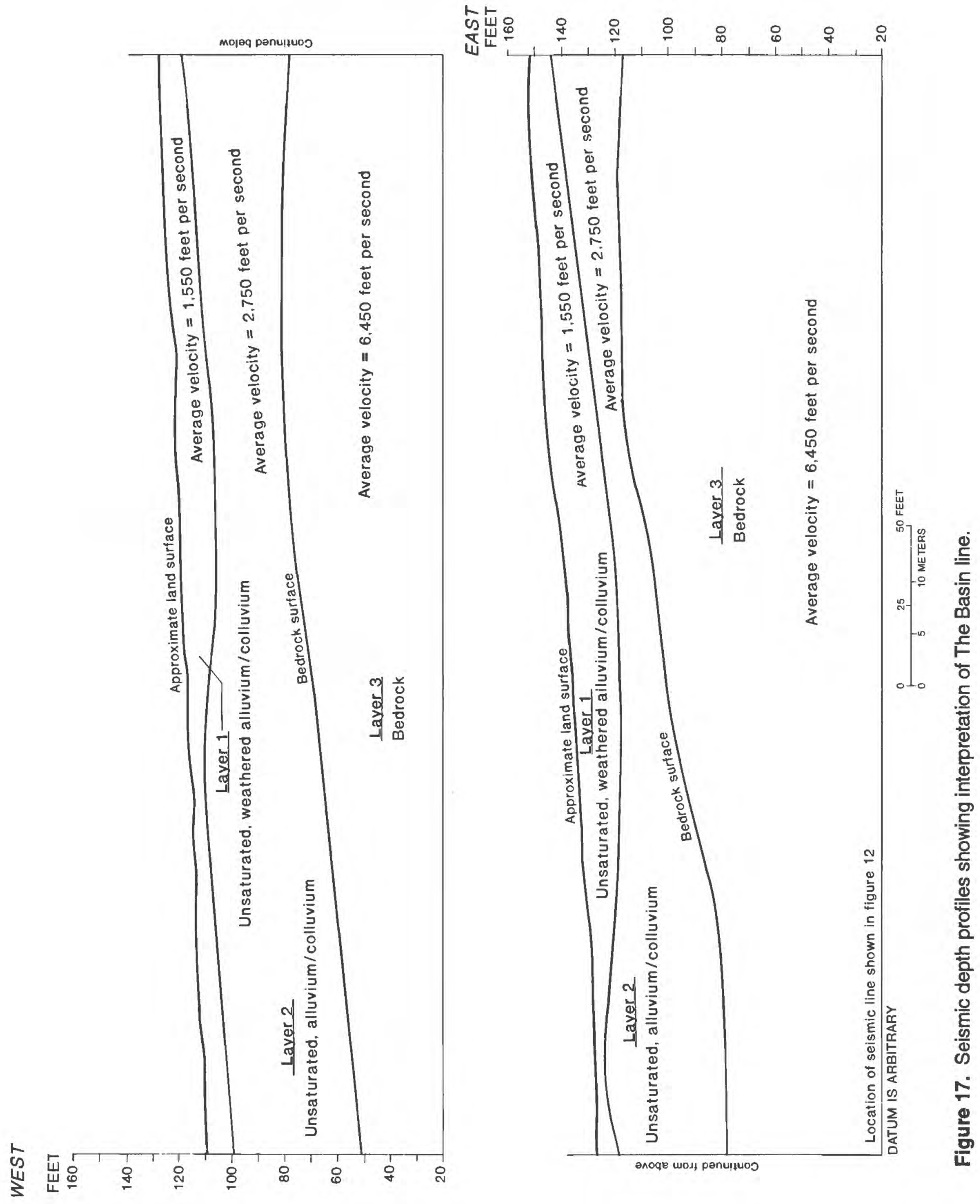
Table 2. Seismic velocity and depth to layers interpreted from refraction survey, Chisos Mountains area [B., The Basin; O.S., Oak Spring; --, not detected]

\begin{tabular}{|c|c|c|c|c|c|}
\hline \multirow{2}{*}{$\begin{array}{c}\text { Seismic } \\
\text { line }\end{array}$} & \multicolumn{3}{|c|}{$\begin{array}{l}\text { Seismic velocity, } \\
\text { in feet per second }\end{array}$} & \multicolumn{2}{|c|}{$\begin{array}{l}\text { Depth to layer, } \\
\text { range in foet }\end{array}$} \\
\hline & Layer 1 & Layer 2 & Layer 3 & Layer 2 & Layer 3 \\
\hline${ }^{1} \mathrm{~B} .1$ & 1,300 & 2,500 & 6,600 & 1- 9 & $37-49$ \\
\hline${ }^{1}$ B. 2 & 1,600 & 3,300 & 6,450 & $11-19$ & $43-53$ \\
\hline${ }^{1}$ B. 3 & ${ }^{2} 1,500$ & 2,400 & 6,400 & $7-18$ & $23-34$ \\
\hline O.S.1 & ${ }^{2} 1,500$ & 2,950 & 6,200 & $7-15$ & $31-49$ \\
\hline O.S. 2 & 1,350 & 2,600 & 7,150 & $8-23$ & $30-42$ \\
\hline O.S.3 & ${ }^{2} 1,500$ & 2,650 & 9,550 & $10-19$ & $13-83$ \\
\hline O.S.4 & 21,500 & 2,100 & 7,300 & $0-19$ & $22-38$ \\
\hline O.S.5 & ${ }^{2} 1,500$ & 3,900 & - & 2- 9 & -- \\
\hline O.S.6 & ${ }^{2} 1,500$ & 2,100 & 9,050 & $1-10$ & $57-62$ \\
\hline O.S.7 & 2,150 & 3,900 & 8,200 & $19-27$ & $73-90$ \\
\hline O.S.8 & 1,700 & 3,900 & 5,650 & $1-16$ & $46-67$ \\
\hline O.S.9 & 1,450 & 4,600 & 6,200 & $10-17$ & $56-62$ \\
\hline O.S.10 & ${ }^{2} 1,500$ & 3,250 & 9,450 & $1-11$ & $47-64$ \\
\hline O.S.11 & ${ }^{2} 1,500$ & 3,800 & - & $2-10$ & - \\
\hline O.S.12 & 1,450 & 2,300 & 7,000 & $2-23$ & $33-47$ \\
\hline O.S.13 & ${ }^{2} 1,500$ & 2,450 & 5,900 & $1-12$ & $26-32$ \\
\hline O.S.14 & ${ }^{2} 1,500$ & 2,350 & 6,350 & $3-14$ & $39-57$ \\
\hline O.S.16 & ${ }^{2} 1,500$ & 2,200 & 7,050 & $12-31$ & $58-65$ \\
\hline O.S.17 & 1,400 & 3,600 & - & $2-26$ & -- \\
\hline
\end{tabular}

1 B.1, B.2, and B.3 indicated collectively by one line in figures 12 and 17 .

2 Programmed default velocity for layer 1.

along seismic line O.S.3, borehole TB-7 along line O.S.12, and borehole TB-6 along line O.S.17 (fig. 14). Consequently, only the interpretations for seismic lines O.S.3, O.S.12, and O.S.17 are illustrated in this report (figs. 18, 19, and 20, respectively). Only for borehole TB-5 and line O.S.3 did the lithologic boundaries from the borehole coincide with the velocity boundaries from the seismic interpretation (fig. 18)--velocity layer $1(1,500 \mathrm{ft} / \mathrm{s})$ coincided with unsaturated, weathered alluvium/colluvium; velocity layer $2(2,650 \mathrm{ft} / \mathrm{s})$ coin- cided with unsaturated, bouldery rhyolitic colluvium; and velocity layer $3(9,550 \mathrm{ft} / \mathrm{s})$ coincided with interlayered compacted clay and sandstone or bedrock. For borehole TB-7 and line 0.S.12 (fig. 19), velocity layer $1(1,450 \mathrm{ft} / \mathrm{s})$ is undoubtedly unsaturated, weathered alluvium/colluvium; layer $2(2,300 \mathrm{ft} / \mathrm{s})$ is unsaturated, bouldery rhyolitic colluvium; and layer $3(7,000 \mathrm{ft} / \mathrm{s})$ is interlayered compacted clay and sandstone or bedrock. And finally for borehole TB-6 and line O.S.17 (fig. 20), velocity layer $1(1,400 \mathrm{ft} / \mathrm{s})$ is undoubtedly unsaturated, 


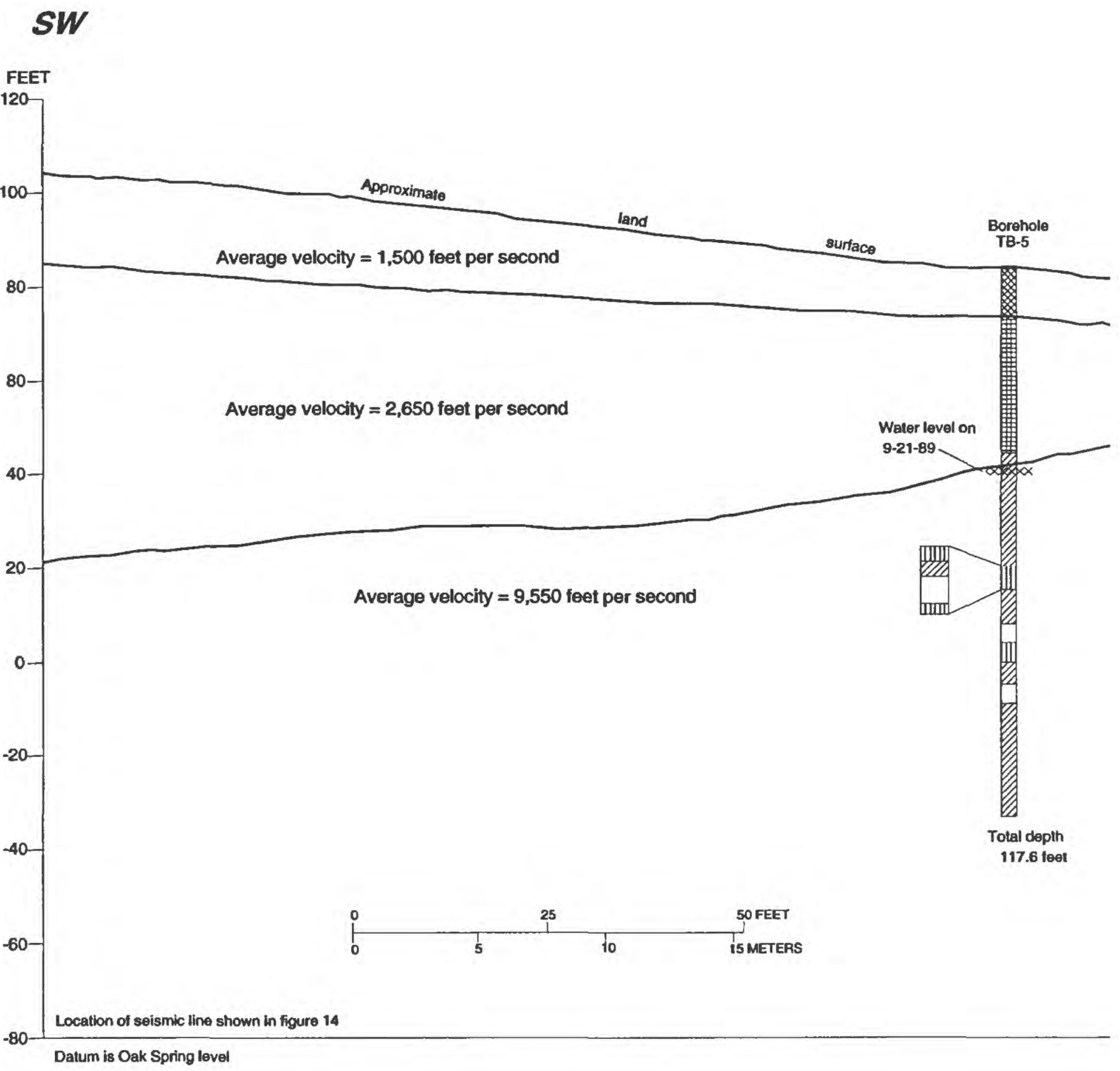

Figure 18. Seismic depth profiles showing interpretation of Oak Spring line O.S.3. 


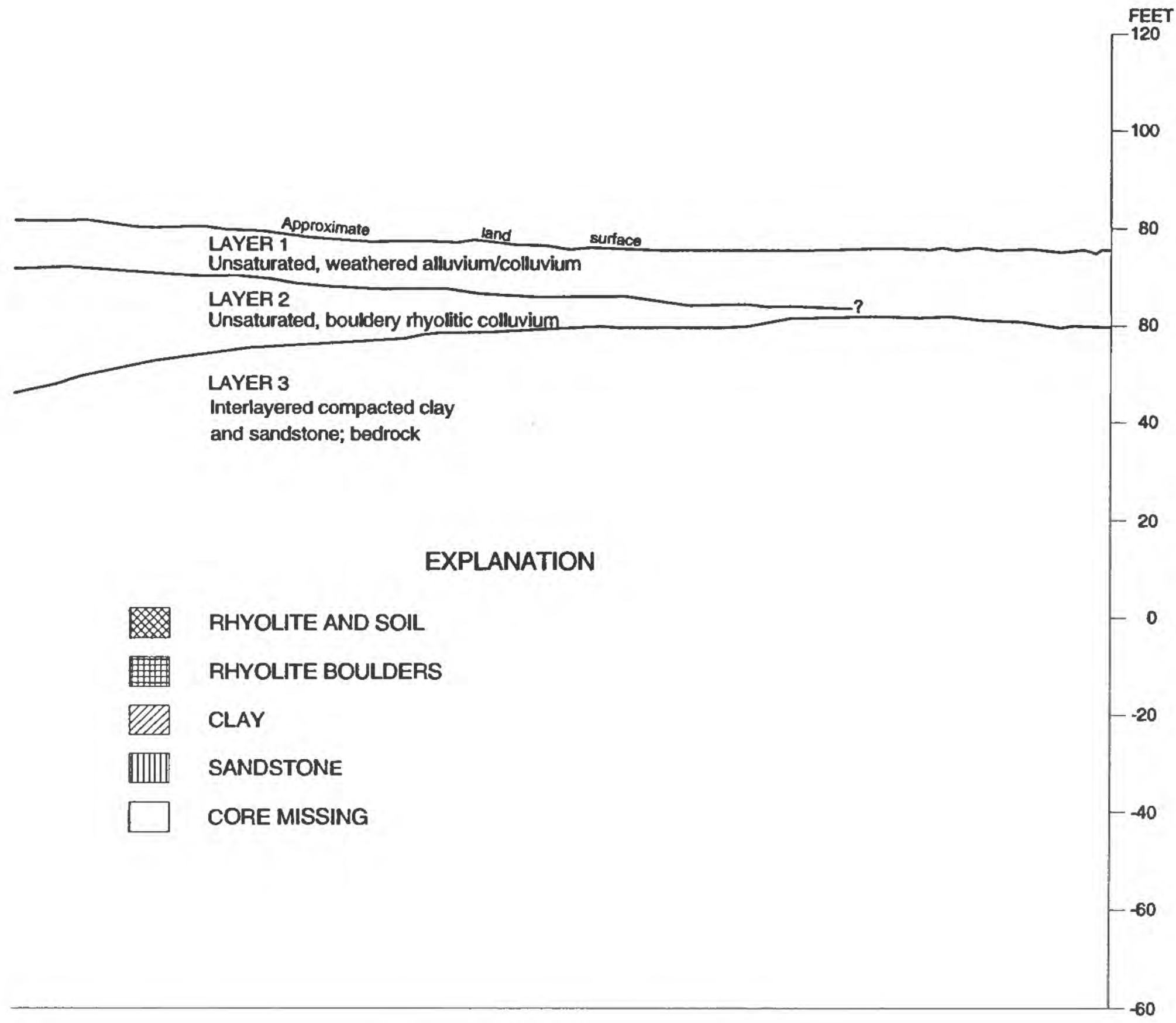




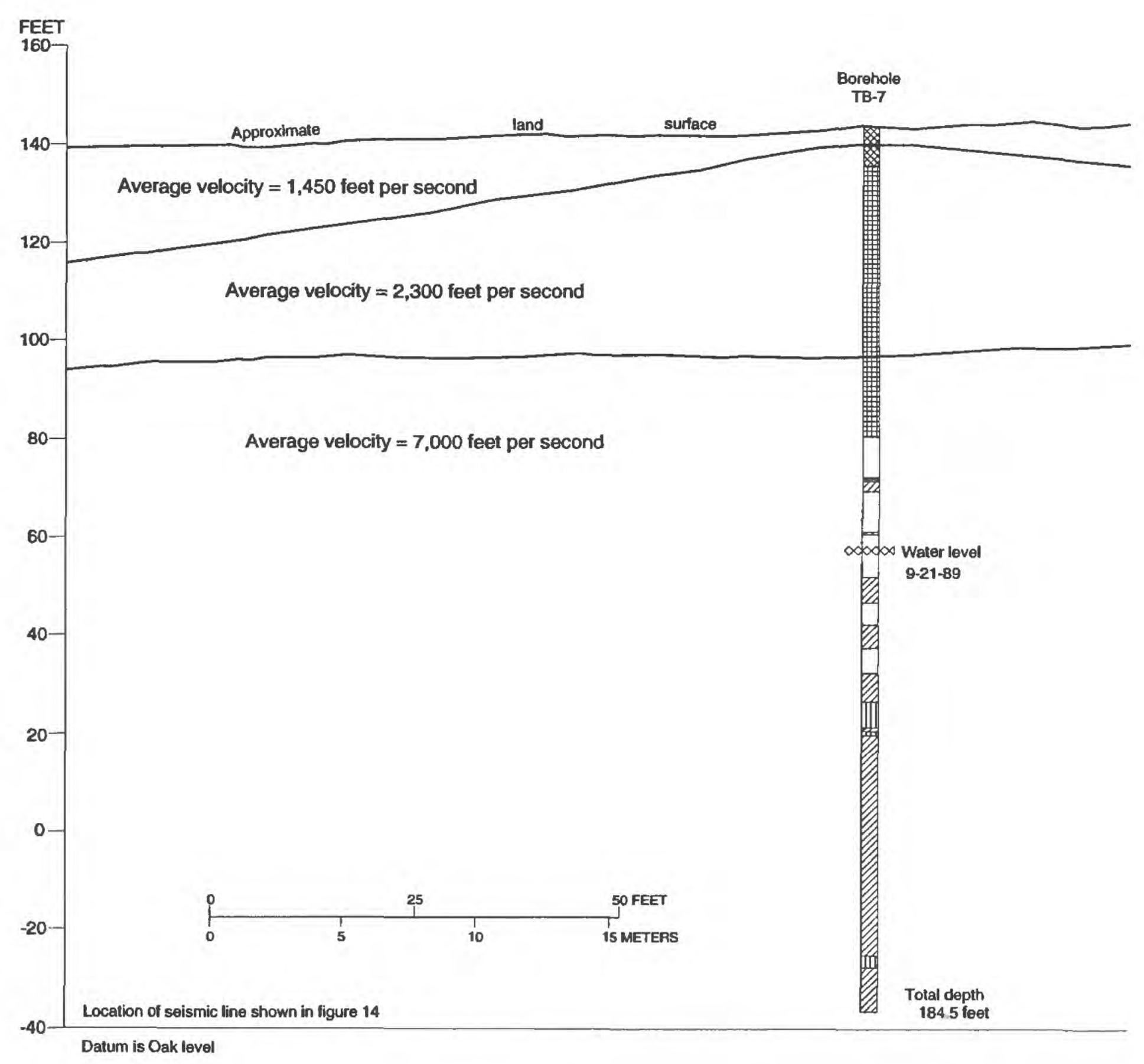

Figure 19. Seismic depth profiles showing interpretation of Oak Spring line O.S.12. 


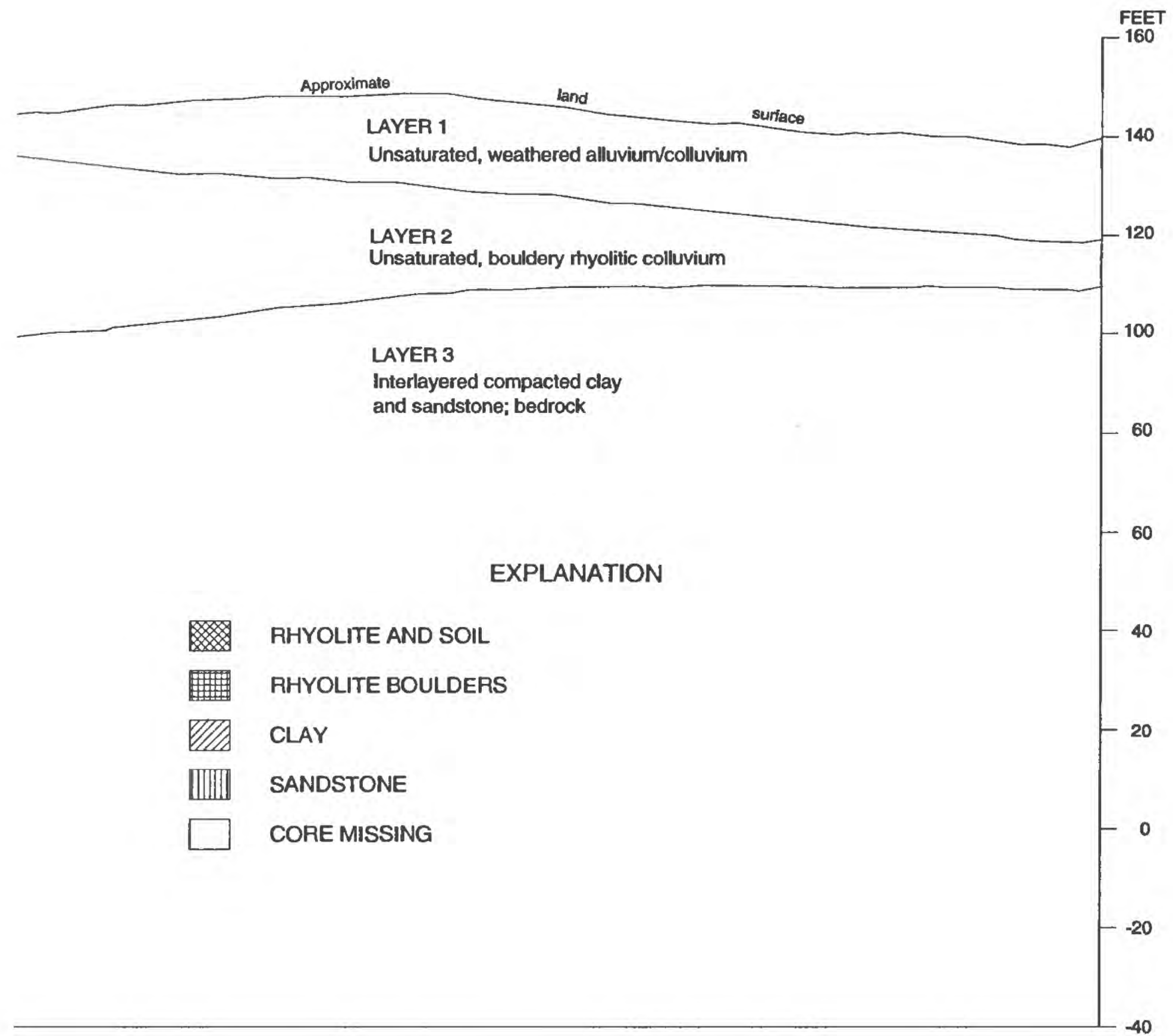




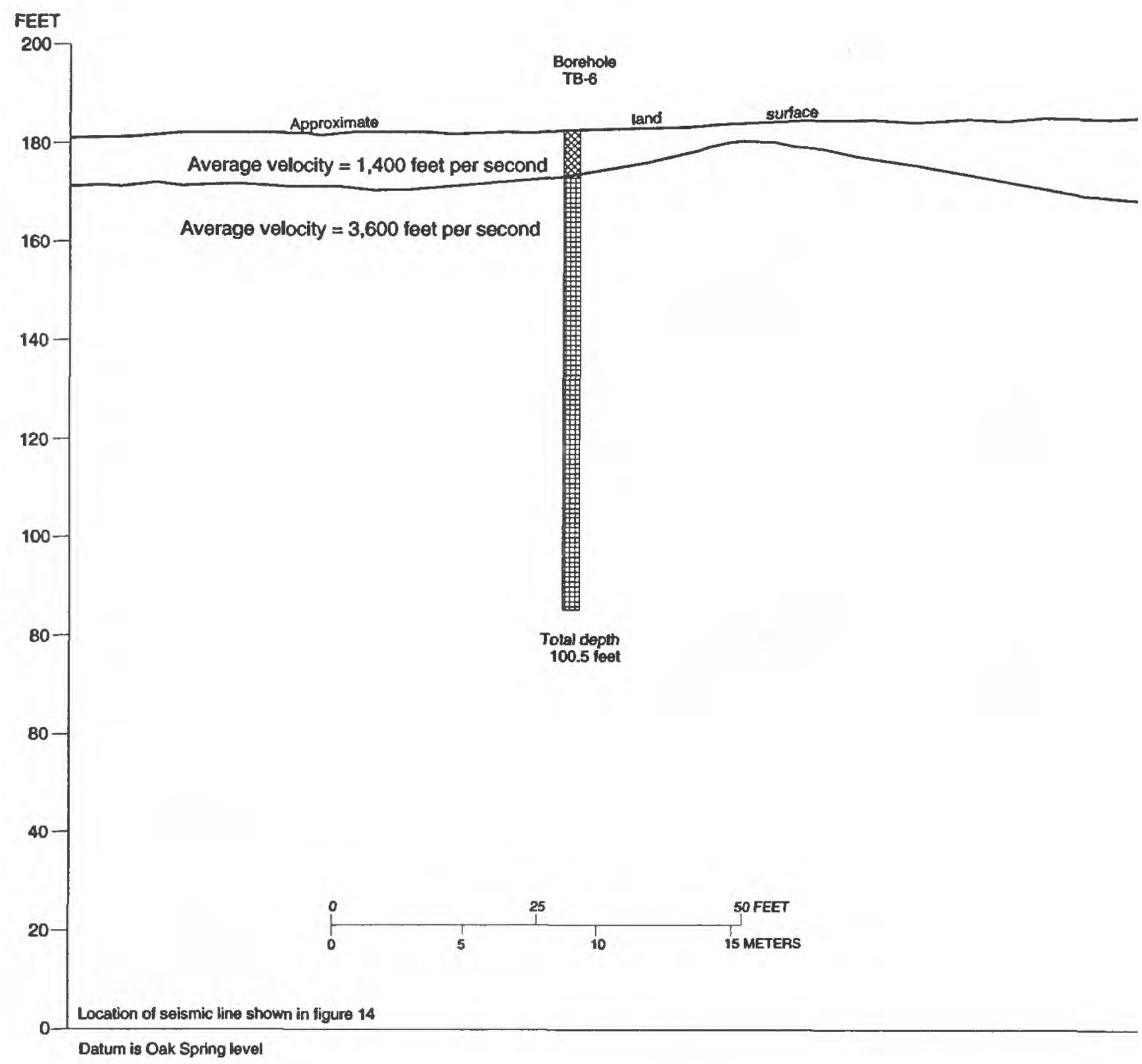

Figure 20. Seismic depth profiles showing interpretation of Oak Spring line O.S.17. 


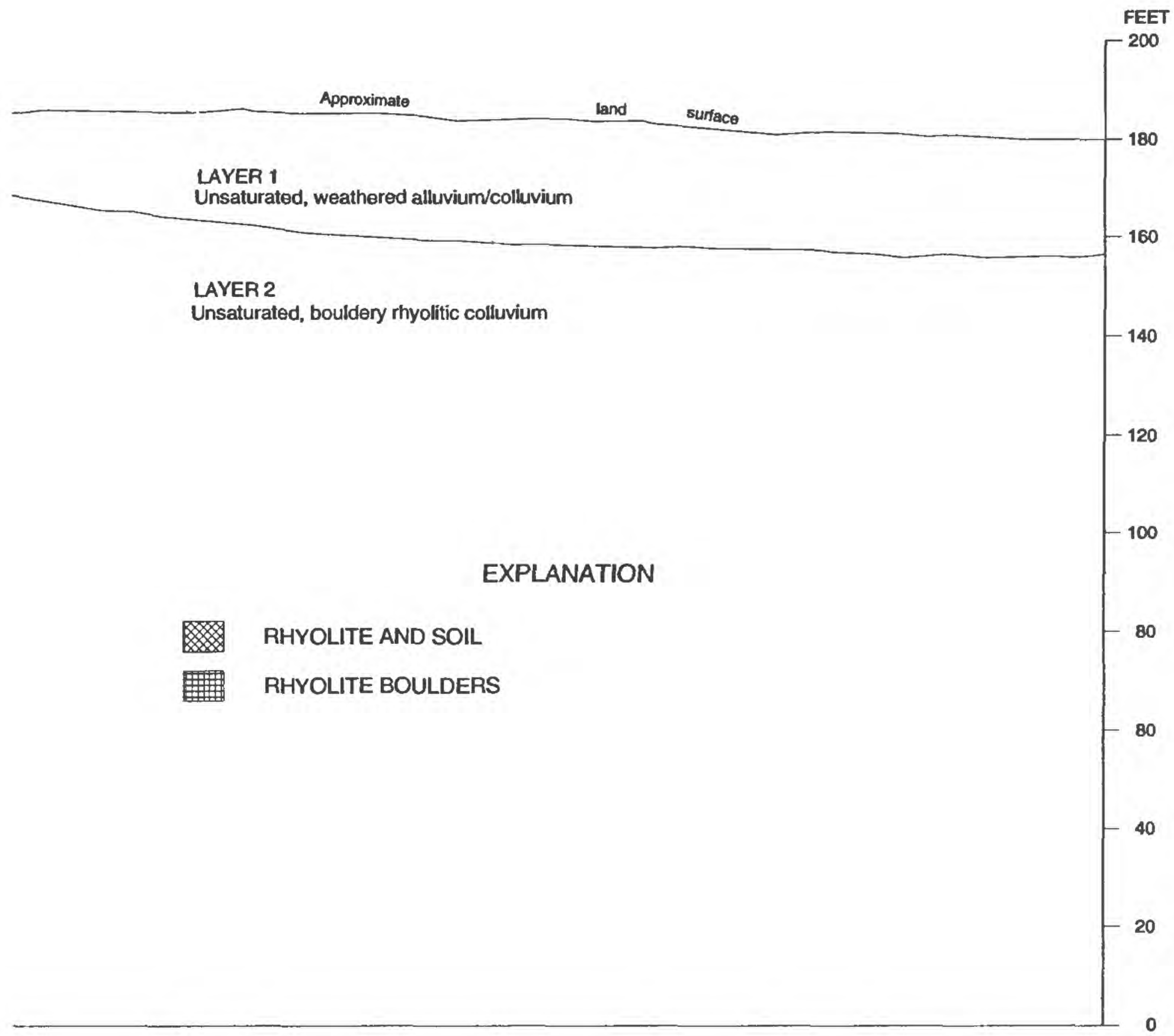


Table 3. Seismic velocities and assigned lithologies for subsurface layers, Chisos Mountains area

[>, greater than]

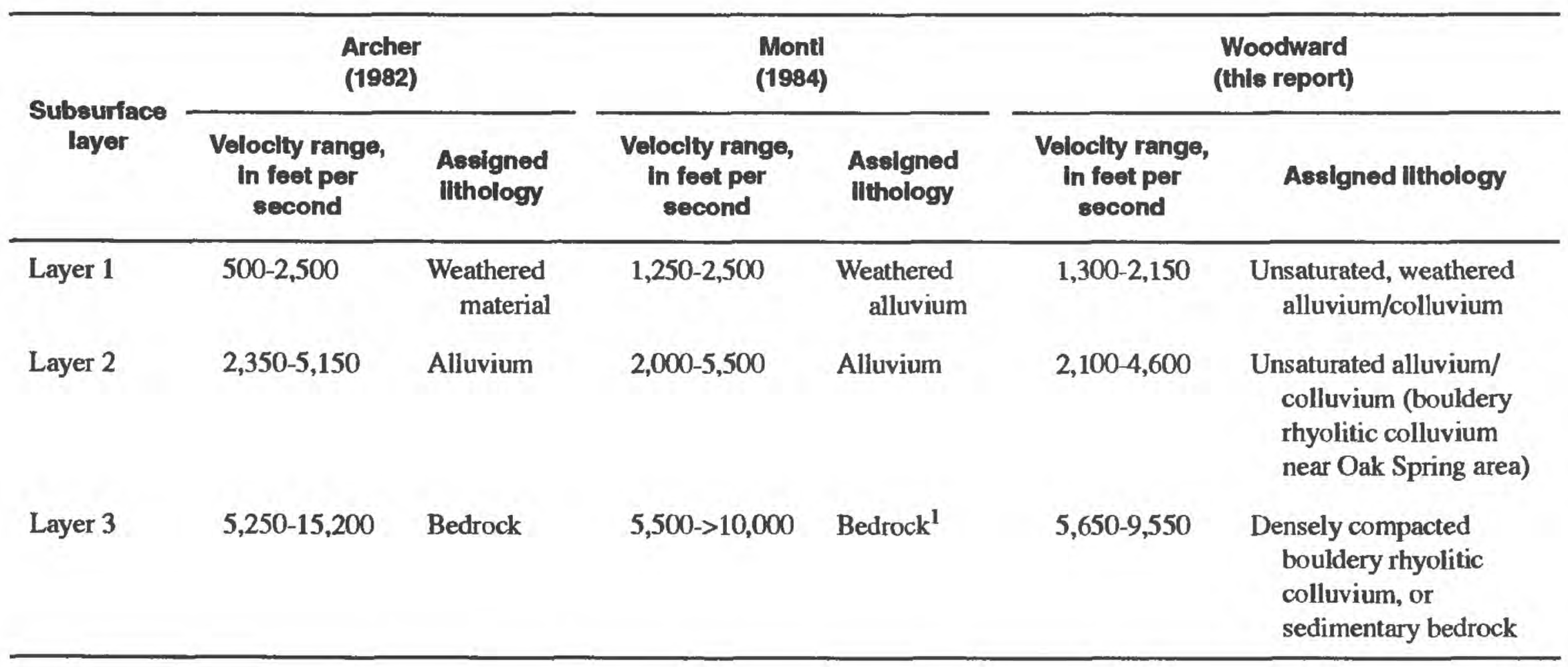

1 Velocities 5,500-10,000 feet per second were assigned as sedimentary bedrock. consisting primarily of interbedded sandstone, siltstone, and shale. Velocities $>10,000$ feet per second were assigned as igneous bedrock.

weathered alluvium/colluvium, and layer $2(3,600 \mathrm{ft} / \mathrm{s})$ appears to be unsaturated, bouldery rhyolitic colluvium; a deeper, third velocity layer was not detected.

In conclusion, the anticipated three-layer earth model consisting of an unsaturated alluvium layer over a saturated alluvium layer over a bedrock layer could not be substantiated either by the interpretations of the refraction data or by the boreholes. A distinctive water table could not be determined within the alluvial/colluvial section. The refraction data indicate that: (1) Layer 1 ranges in seismic velocity between about 1,350 and $2,150 \mathrm{ft} / \mathrm{s}$, consists of unsaturated, weathered alluvium/ colluvium near the land surface, and ranges in thickness from 0 to $31 \mathrm{ft}$; (2) layer 2 ranges in seismic velocity between about 2,100 and $4,600 \mathrm{ft} / \mathrm{s}$, consists of unsaturated boulders, rhyolitic colluvium, and ranges in thickness from 3 to $63 \mathrm{ft}$; and (3) layer 3 ranges in seismic velocity between about 5,650 and $9,550 \mathrm{ft} / \mathrm{s}$, and consists of either unsaturated, densely compacted bouldery rhyolitic colluvium or saturated/unsaturated sedimentary bedrock. Generally, the top of layer 3 slopes to the south and southwest.

\section{Flow of Oak Spring}

Continuous monitoring of the flow of Oak Spring began December 12, 1986, when the Park Service installed a Stevens Type A-71 recorder on a newly constructed concrete weir box at the spring site. ${ }^{2}$ From that time to December 7,1989 , flow rates have been recorded almost continuously.

\section{Precipitation-Spring Flow Relation}

Daily precipitation at The Basin ranger station from January 1986 to December 1989 along with the

2 This new concrete weir box tied onto an existing concrete collection box, which had apparently been in place for many years to capture a major portion of Oak Spring flow for potable use in The Basin. The spring opening has been developed by placement of a pipe into the face of the slope. The developed opening is along a spring line 30 to $40 \mathrm{ft}$ long. Flow issuing from other openings along the spring line could total 20 to $25 \mathrm{gal} / \mathrm{min}$ during high-flow periods and is correspondingly lower, approaching zero, at very low-flow times. These waters not collected in the new concrete weir box, together with "overflow" water from the water distribution system when the storage tanks are full, are permitted to flow naturally in the spring-line area and to flow downgradient to lower Oak Creek in support of native vegetation (William Werrell, National Park Service, written commun., 1990). 
daily discharge of Oak Spring from December 12, 1986, when the recorder went into operation, to December 7, 1989, are shown graphically in figure 21 . During this period of record, flow rates at Oak Spring declined from a high of $167 \mathrm{gal} / \mathrm{min}$ on December 12, 1986 , to $115 \mathrm{gal} / \mathrm{min}$ in late April 1987, recovered to $129 \mathrm{gal} / \mathrm{min}$ in mid June, declined to a low of $94 \mathrm{gal} /$ min in late August, and finally began a rapid recovery, reaching $121 \mathrm{gal} / \mathrm{min}$ on October 8-10, 1987. Thereafter, records show that spring flow declined overall for the next 26 months, of which 20 months had belownormal precipitation. (Normal annual precipitation is 18.34 in. at The Basin ranger station.) During this 26month period, spring flow dropped to a low of $22.4 \mathrm{gal} /$ $\min$ on December $2-4,1989$. At the end of the period of record on December 7,1989, the flow had recovered only slightly to $23.8 \mathrm{gal} / \mathrm{min}^{3}$

Further evidence of the close relation between flow rates and precipitation is shown in figure 21 . The high flow of $167 \mathrm{gal} / \mathrm{min}$ in December 1986 was caused by heavy precipitation earlier in the year. A record 33.69 in. was recorded in The Basin in 1986, and of that amount, $31.21 \mathrm{in}$. occurred prior to the high flow of 167 $\mathrm{gal} / \mathrm{min}$ on December 12. It is reasonable to expect that flow rates substantially exceeded the $167 \mathrm{gal} / \mathrm{min}$ recorded in December 1986 at some earlier time during the year, most probably during late summer to early fall (from August to October), which was a period of exceptionally intense and prolonged precipitation in The Basin and at Panther Junction. Flow rates continued to decline in 1987 from decreased precipitation (relative to 1986) until fairly heavy precipitation in April and May caused the flow to reach an interim peak in June. The relation between precipitation and flow rates continued from June to September 1987, when very heavy August precipitation caused an upturn in flow beginning in late August and continuing to early October. Similar relations occurred in 1988 when spring flow peaked in July and August from relatively heavy precipitation about 25 to 35 days previous to the peaks. In a like manner, the slight increase in flow of 4 $\mathrm{gal} / \mathrm{min}$ in mid-March 1989 resulted from $2.16 \mathrm{in}$. of precipitation in mid-February 1989. A lag time of about 1 month appears to be normal. The fairly rapid response of flow rates to precipitation--a pressure

\footnotetext{
${ }^{3}$ On June 18, 1990, William Werrell measured a flow of $20.5 \mathrm{gal} / \mathrm{min}$. As reported by Big Bend National Park officials, precipitation occurred a few days later, and after that, discharge rose (William Werrell, National Park Service, written commun., 1990).
}

effect--indicates a shallow aquifer, effective recharge areas, and extremely permeable aquifer material.

Prior to the present study, 29 miscellaneous spring-flow measurements were made for Oak Spring from 1953 to 1972 . On the basis of these measurements, the flow ranged from 6 to $80 \mathrm{gal} / \mathrm{min}$. The low flow of $6 \mathrm{gal} / \mathrm{min}$ was measured in 1956 near the end of 6 consecutive years of below-normal precipitation.

\section{Diurnal Fluctuations}

Close inspection of part of the recorder chart (fig. 22) indicates diumal fluctuations in flow every 24 hours during the warm growing seasons. This hydrologic phenomenon at Oak Spring is illustrated in figure 22 for July 5-7, 1987. During this period, daily high flows ranged from 124 to $126 \mathrm{gal} / \mathrm{min}$, while corresponding daily low flows ranged from 121 to $123 \mathrm{gal} /$ min. The maximum difference in flow during each day was $3 \mathrm{gal} / \mathrm{min}$. The higher flows generally persisted over a 12-hour period from about 2000 hours (8:00 p.m.) to about 0800 hours (8:00 a.m.); the lower flows generally were associated with the daylight hours, beginning a decline about 0800 , reaching a minimum flow about 1500 hours (3:00 p.m.), and returning to a maximum at about 2000 hours.

The diumal variation in flow at Oak Spring is caused by the process of evapotranspiration acting on shallow ground water above and along the spring line. The near-surface ground water up-slope and on either side of the spring collection box supports a dense growth of vegetation. This is visible as a luxuriant "green belt" having well-defined borders north, east, and west of the spring, and it appears in stark contrast to adjacent less-vegetated areas (fig. 7B). On the basis of an inventory made by Betty Alex (National Park Service, Big Bend National Park, oral commun., March 17,1988 ), this dense plant community is about 60 percent Evergreen sumac (Rhus virens) and about 20 percent mixed Acacia and Mimosa species including some catclaw. The remaining 20 percent includes several Texas Persimmon (Diospyros texana) at and near the spring opening, a large Palo prieto (Vauquelinia angustifolia), a Mexican-buckeye (Ungnadia speciosa) at the spring opening, and a large Gregg's ash (Fraxinus greggii). The permanency of Oak Spring is indicated by these plants, which thrive only where a perennial supply of ground water is present.

Climatic conditions affect the rate that water from the Oak Spring aquifer is used by the vegetation 


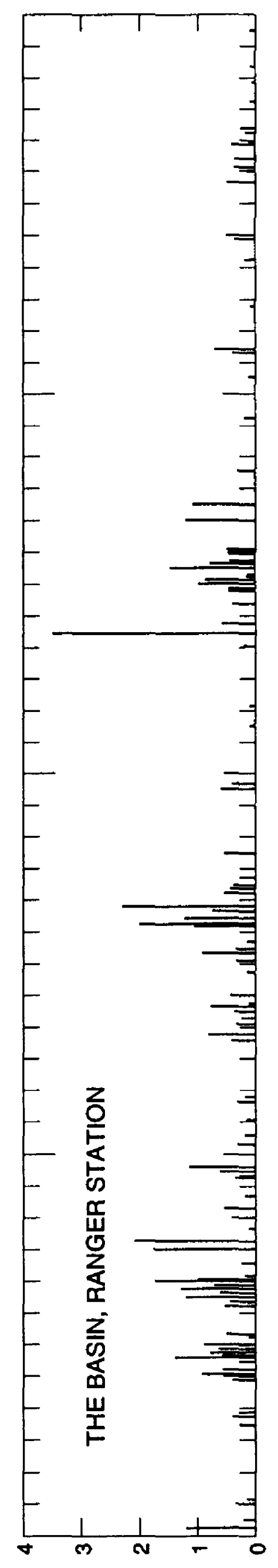

SتHONI NI 'NOII $\forall I I D I O \exists H d$ ᄉาI $\forall 07 \forall 101$

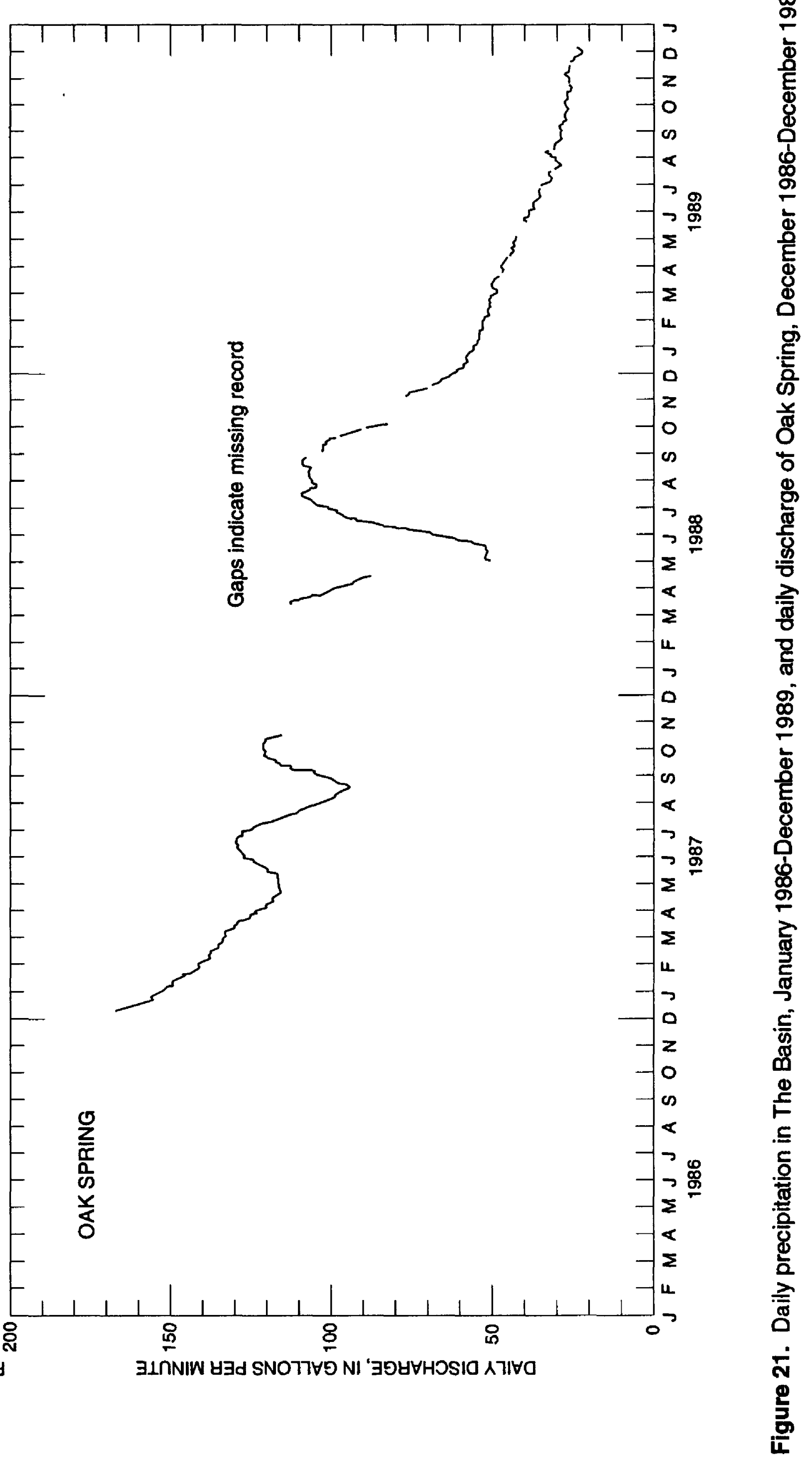




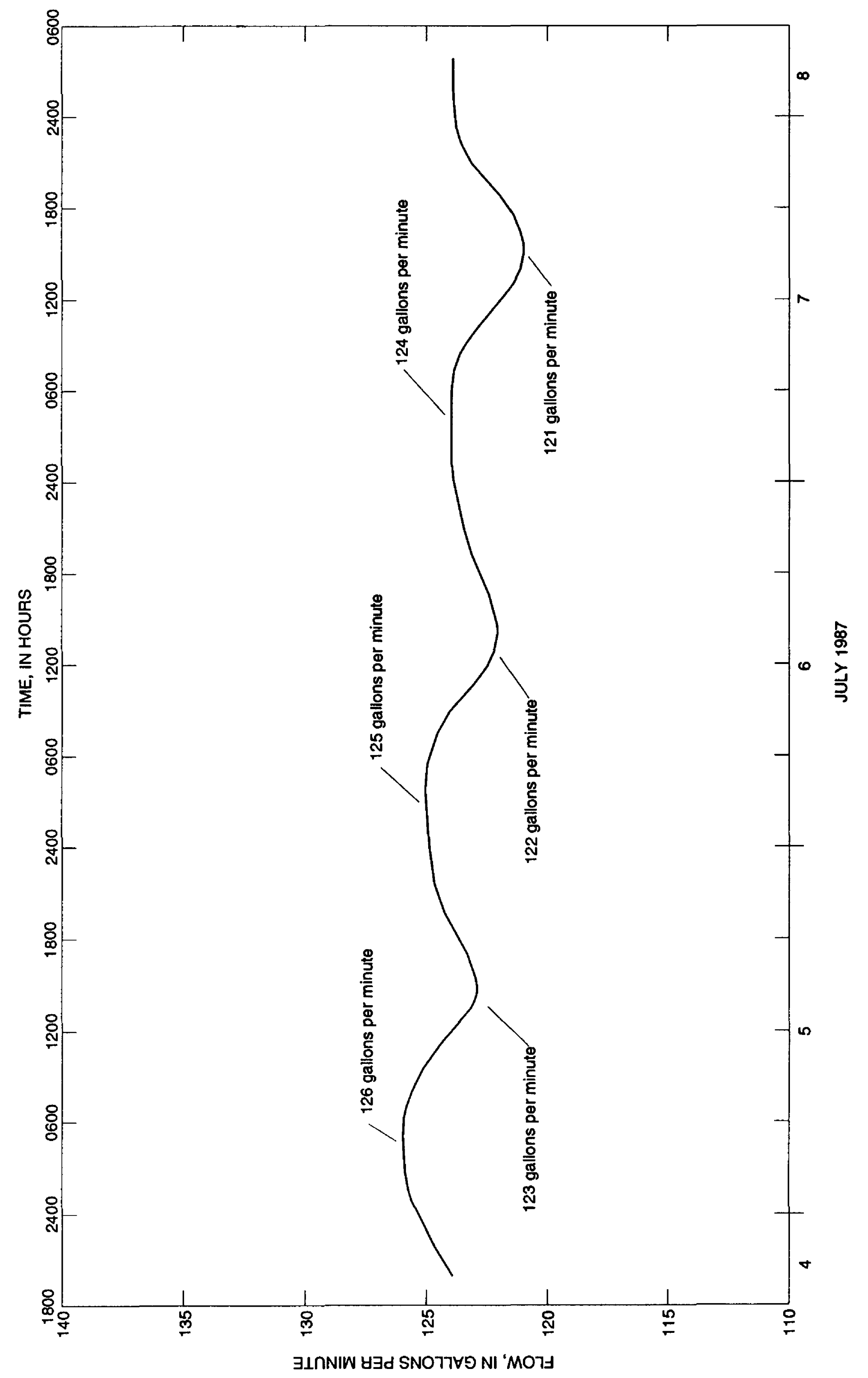

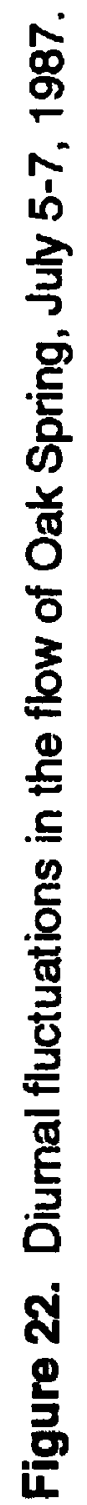


and lost to evaporation near the surface. This, in turn, affects the magnitude of the daily variations in the flow of Oak Spring. The climatic factor that exerts the greatest effect on water consumption is the air temperature. Transpiration, with its attendant water requirements, takes place primarily during daylight hours, when temperatures are greater than at night, and plants use sunlight in the process of photosynthesis. The more intense the sunlight and the longer the daylight hours, the more water is used by plants. For example, during the 3-day period represented by the hydrograph in figure 22 , the differences in the maximum and minimum daily temperatures on July 5,6, and 7 at the Panther Junction weather station averaged $30^{\circ} \mathrm{F}$. (The temperature differential at Oak Spring is about the same as at Panther Junction because of similarities in elevation.) Each year the diurnal fluctuations of flow at Oak Spring are imperceptible in winter, when transpiration is at a minimum, and become noticeable as very subdued fiuctuations at the beginning of the growing season. In 1987, the fluctuations were first apparent in early May, and became imperceptible in early November.

\section{GEOCHEMISTRY AND QUALITY OF GROUND WATER}

Ground-water quality at Oak Spring and at wells and springs in the vicinity of The Basin has been monitored intermittently since 1953 by the Geological Survey and the Park Service. Analyses generally have been made for major elements and physical properties. The Park Service also has analyzed Oak Spring discharge for two selected pesticides--mirex and silvex-during the 1970's. A geochemical study of ground water in The Basin area (Lopez-Sepulveda, 1984, p. 94) concluded that Oak Spring discharge is typical of a fast flow system from the Chisos Mountains with recent recharge. These interpretations were based on the tritium activity of the spring discharge and the similar temperatures observed during the winter and summer sampling of Oak Spring during 1983. In the present study, more constituents were used to determine the effects of human activity in The Basin on Oak Spring water quality. The following procedures were implemented to investigate the potential for contamination: (1) Assess the past and current (1986-89) quality of ground water at Oak Spring, (2) investigate potential sources of ground water that discharge at Oak Spring, and (3) assess the relation of The Basin aquifer to the Oak Spring aquifer.

\section{Data Collection and Analytical Procedures}

Chemical data consisting of laboratory analyses of ground-water samples were compiled from the files of the Geological Survey and Park Service, and from Lopez-Sepulveda (1984, p. 28, 29, and 31). These data were supplemented by samples collected during June 1986 and August 1987 within The Basin from the lower CCC well, Window Spring, and the lower sewage lagoon. Samples also were collected during those times outside The Basin from Oak Spring and Cattail Falls (fig. 3). In addition, two water samples were collected during June 1986 from Oak Spring and the lower sewage lagoon for bacterial analysis. Samples were collected during March 1988 for microbial and viral analyses from Oak Spring, Cattail Falls, the lower CCC well, Window Spring, and from a tap in The Basin water distribution system.

Water samples obtained during this study were collected either from flowing sources or after pumping a minimum of one-half hour to ensure the collection of representative samples and minimize chemical interferences from the pump and sample tubing. Measurements of specific conductance, $\mathrm{pH}$, alkalinity, and temperature were performed in the field according to the procedures outlined by Wood (1976). Dissolvedoxygen measurements were obtained at Oak Spring and the lower CCC well using a YSI model 54A oxygen meter and probe. Water samples collected for analysis of element cations and minor elements were acidified upon collection with $1 \mathrm{~mL}$ of nitric acid. Nutrient and nitrogen isotopic samples were preserved with mercuric chloride. All samples except the acidified and anion samples were preserved by refrigeration between their collection and analysis.

Water samples submitted for analysis of volatile and semivolatile organic compounds were collected using a submersible pump equipped with Teflon and stainless steel fittings and teflon tubing to minimize sample contamination. These samples were spiked with a solution of surrogate compounds to evaluate potential losses of volatile and semivolatile compounds between collection and analysis.

Microbial and viral determinations were made on samples from selected locations in The Basin and Oak Spring areas and Cattail Falls to determine the presence of indicators of human and animal pollution. The indicators of pollution examined in the samples included: (1) The enteric viruses poliovirus, coxsackievirus $\mathrm{A}$ and $\mathrm{B}$, echovirus, reovirus, and adenovirus; 
Rotavirus and Norwalk agent; and the Hepatitis A virus; (2) the Protozoan parasite Giardia lamblia; and (3) bacterial determinations of total-coliform, fecalcoliform, and fecal-streptococcal densities.

Samples for bacterial and enteric virus determinations were collected from Oak Spring, the pool below Cattail Falls, the lower CCC well, Window Spring, and, to represent the chlorinated water supply of The Basin, a tap (picnic site 44) in The Basin campground (fig. 3). Samples for the Protozoan parasite Giardia lamblia were collected from Oak Spring, Cattail Falls, and Window Spring. Bacterial samples were collected directly from the sample sources using either a submersible pump (lower CCC well), from an existing faucet (picnic site 44), or by dipping a sterilized bottle with a prophylactically-protected hand (covered with a prerinsed latex glove). Samples for viral analysis were collected by pumping through a sterilized, rinsed tube, pump and filter assembly. Viruses were concentrated from water using an adsorption/elution technique onto an electropositive filter (American Public Health Association, 1985). Because of the potential health effect of small numbers of enteric viruses and Giardia lamblia, large volumes of water $(1,013$ to $1,036 \mathrm{~L})$ were filtered. A similar filtration mechanism was used for concentration of Giardia lamblia onto a yarn-wound, polypropylene cartridge filter with a $1.0-\mu \mathrm{m}$ pore size, using between 113 and $151 \mathrm{~L}$ of water for sample concentration. Filters for enteric virus and Giardia determination were then shipped on ice for elution and analysis to the laboratory at the Department of Microbiology and Immunology, University of Arizona, Tucson, Arizona.

Inorganic and nutrient analyses were performed according to procedures outlined in Fishman and Friedman (1985). Organic analyses, with the exception of determinations of semivolatile organic compounds, were performed using procedures described by Wershaw and others (1983). The determinations of semivolatile organic compounds were performed using procedures outlined in Barber and others (1988). Determinations of total-coliform, fecal-coliform, and fecalstreptococcal bacteria were made in accordance with procedures described in Greeson and others (1977).

\section{Hydrochemical Framework}

When viewed in context of the regional hydrogeology, water chemistry at each of the sampled locations can be considered characteristic of a potential pathway of geochemical evolution within The Basin and Oak Spring aquifers. The water chemistry from Window Spring represents ground water derived from recent precipitation. This water has flowed through fill material and the entire suite of rocks exposed within The Basin, including possible water-bearing beds of Upper Cretaceous age. Water chemistry from the lower $\mathrm{CCC}$ well represents ground water from either alluvial and colluvial deposits of The Basin or from an Aguja aquifer. Cattail Falls water chemistry represents water from a pristine watershed located on igneous intrusive rock. The chemistry of water from the lower sewage lagoons represents treated sewage from human activities in The Basin.

\section{Major and Minor Inorganic Constituents}

The results of chemical analyses of 33 water samples from Oak Spring, a pool below Cattail Falls, the lower CCC well, Window Spring, and the lower sewage lagoon in The Basin are given in table 4 (at end of report). These data are discussed in relation to their importance in defining potential sources of discharge from, and in defining the water quality of, Oak Spring.

The 1954-83 median concentration of dissolved solids in water from Oak Spring was about $210 \mathrm{mg} / \mathrm{L}$. This value and the June 1986-89 dissolved-solids concentrations ranging from 230 to $240 \mathrm{mg} / \mathrm{L}$ are intermediate between the June 1986 concentrations observed at Cattail Falls ( $76 \mathrm{mg} / \mathrm{L}$ ) and Window Spring (280 $\mathrm{mg} / \mathrm{L})$.

Two water samples that were collected from Cattail Falls during 1954 and 1989 contained dissolvedsolids concentrations of 410 and $510 \mathrm{mg} / \mathrm{L}$, respectively, which were the largest reported from the study area (table 4). The 1989 samples from Cattail Falls were collected when little water discharged over the falls (less than $0.01 \mathrm{ft}^{3} / \mathrm{s}$ ). These analyses probably are not representative of ground-water quality from the pristine watershed above the falls. The 1989 analysis probably was altered by chemical reactions within the pool at the base of the falls and evaporation from the pool surface. Information on flow at the falls was not collected during the 1954 sampling of water from the pool. Therefore, the 1954 and 1989 water samples from Cattail Falls are not discussed with respect to regional geochemical processes affecting water from Window and Oak Springs. 
Major constituents determined by this study included calcium, magnesium, sodium, potassium, bicarbonate (as determined from alkalinity), sulfate, chloride, fluoride, silica, and nitrate. Concentrations of alkalinity (as $\mathrm{CaCO}_{3}$ ), calcium, sodium, and sulfate in ground water from the study area are greater than those reported for ground water from aquifers primarily composed of or derived from igneous rock (Freeze and Cherry, 1979, p. 276; Hem, 1985, p. 70-71 and 98). Examination of specific-conductance, calcium, sulfate, chloride, and nitrate data from Oak Spring shows slight increases with time between determinations made from 1954 to 1969 and those made from 1983 to 1989 (table 4, at end of report). However, variation in specific conductance and concentrations of those constituents do not appear to be related to changes in discharge (fig. 23). The relative stability of dissolved-constituent concentrations at Oak Spring for determinations made from 1983 to 1989 indicates that the processes that affect ground-water chemistry of major constituents in spring discharge are natural and not anthropogenic.

Minor elements determined by this study included bromide, iodide, arsenic, barium, boron, cadmium, chromium, iron, lead, manganese, mercury, selenium, silver, strontium, and zinc. The minor elements with the largest concentrations in water samples analyzed are fluoride, barium, boron, and strontium. Boron concentrations in water from the lower sewage lagoon are the largest of the minor elements among all samples collected. Except for the samples from the lower sewage lagoon, concentrations of these trace elements in water samples may be attributed to the natural mineralogy of The basin and Oak Spring aquifers.

Mineral saturation indices (fig. 24) were computed for water-chemistry data collected in 1986 using the mass transfer-equilibrium speciation model PHREEQE (Parkhurst and others, 1980). A saturation index of zero or greater describes the degree of supersaturation detected in the source water with respect to a specific mineral such as calcite. A saturation index less than zero correspondingly describes the degree of undersaturation in the water source with respect to a mineral. Water samples from Oak Spring and Window Spring were slightly supersaturated with respect to the mineral fluorite. All 1986 samples were slightly supersaturated with respect to amorphous silica (chalcedony). These data indicate that weathering of silicate minerals is occurring in The Basin and Oak Spring aquifers. The source of fluorite is probably from the igneous-related provenance of aquifer material.
All water samples except from the sewage lagoon were undersaturated with respect to calcite. All water samples were undersaturated with respect to gypsum. The saturation indices of calcite and fluorite in ground water from Oak Spring were nearly four times larger than the values determined for water from Window Spring. Undersaturation of water from Window Spring, Oak Spring, and the lower CCC well, with respect to calcite, indicates that it is not present in appreciable amounts in The Basin and Oak Spring aquifers. These data and concentration patterns indicate that dissolution of an additional mineralogic source, such as caliche or other salt accumulations in the unsaturated zone, might contribute calcium and alkalinity (table 4) to ground water from the Oak Spring aquifer. The presence of these mineralogic sources in the unsaturated zone has not been verified.

\section{Hydrochemical Facies}

The concept of hydrochemical facies developed by Back (1966) was used to demonstrate relative differences in the ground-water chemistry between samples collected at each location. Samples from The Basin and Oak Spring areas are generally calcium magnesium bicarbonate dominant waters (fig. 25). Ground water from Window Spring does not have a dominant cation but contains predominantly bicarbonate among the major anions represented on figure 25. The 1986 sample from Cattail Falls contains calcium and magnesium as dominant cations but has no dominant anion. The 1987 sample from Cattail Falls has a larger percentage of sulfate plus chloride than all other samples. The 1987 sample from Cattail Falls is not representative of flow from the watershed above the falls because of the very small discharge at the time of sampling (table 4). Water from the lower sewage lagoon has no predominant cation or ion.

The hydrochemical facies of Oak Spring are similar to those of the lower CCC well and intermediate to those of Cattail Falls and Window Spring (fig. 25). The hydrochemical facies of all samples except the lowflow sample from Cattail Falls contain substantially smaller proportions of sodium and chloride than the water from the lower sewage lagoon. This difference indicates that the hydrochemical facies of groundwater samples from Oak Spring, the lower CCC well, and Window Spring are either similarly affected or sub- 

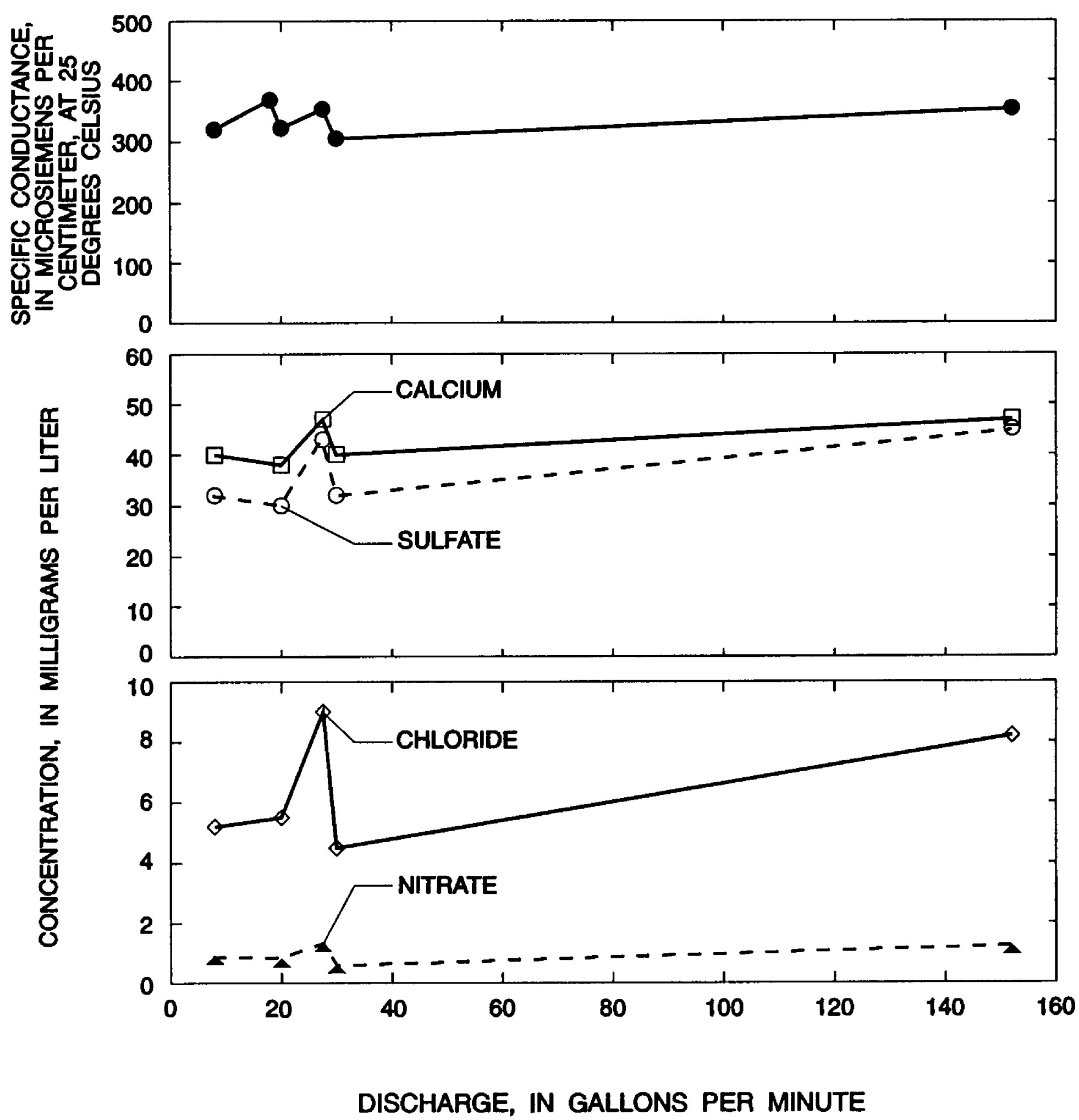

Figure 23. Relation of specific-conductance values and concentrations of calcium, sulfate, chloride, and nitrate to discharge from Oak Spring. 


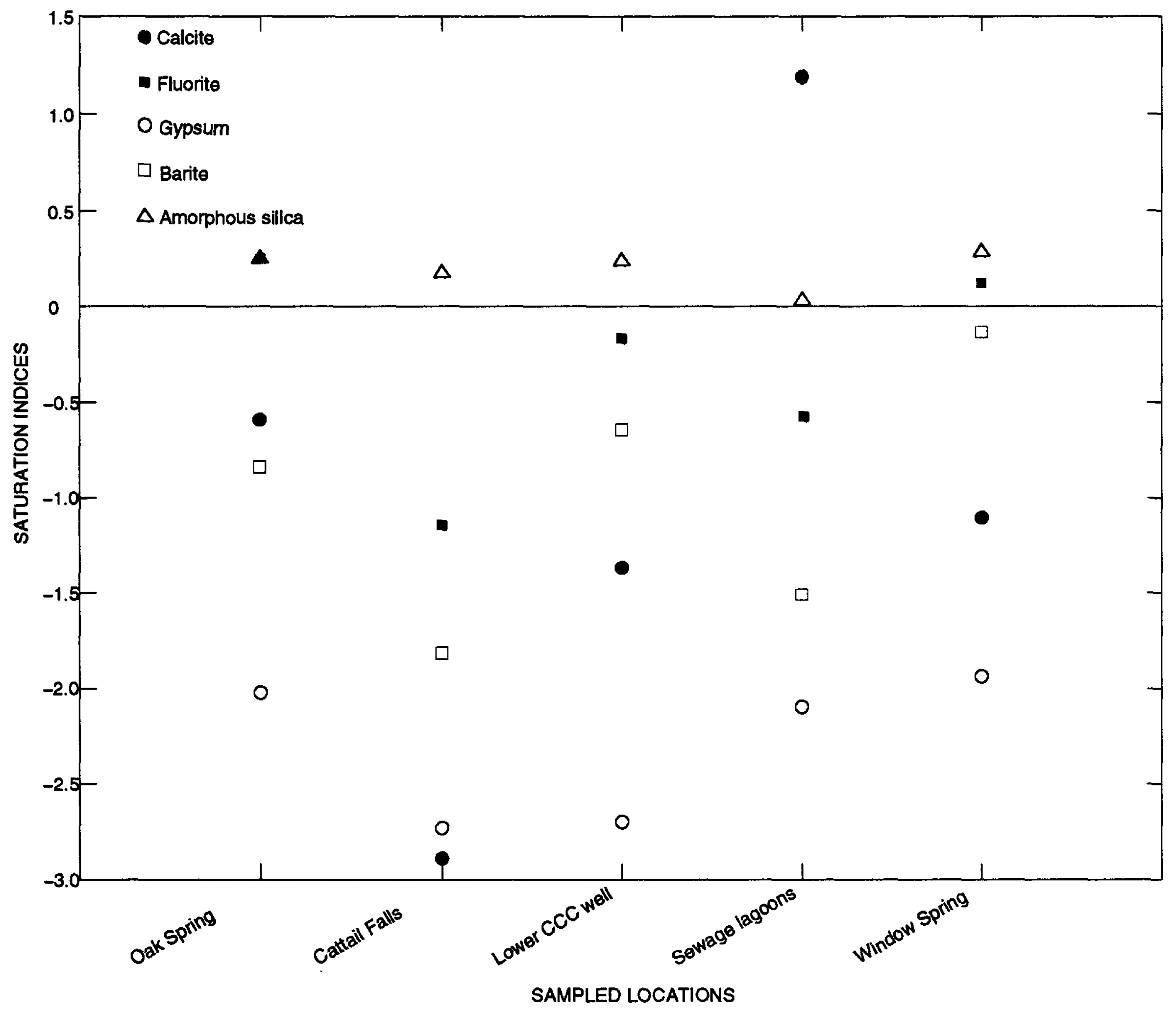

Flgure 24. Mineral saturation indices calculated using the program PHREEQE (Parkhurst and others, 1980) for water samples from The Basin and Oak Spring areas and Cattail Falls, August 1986. 


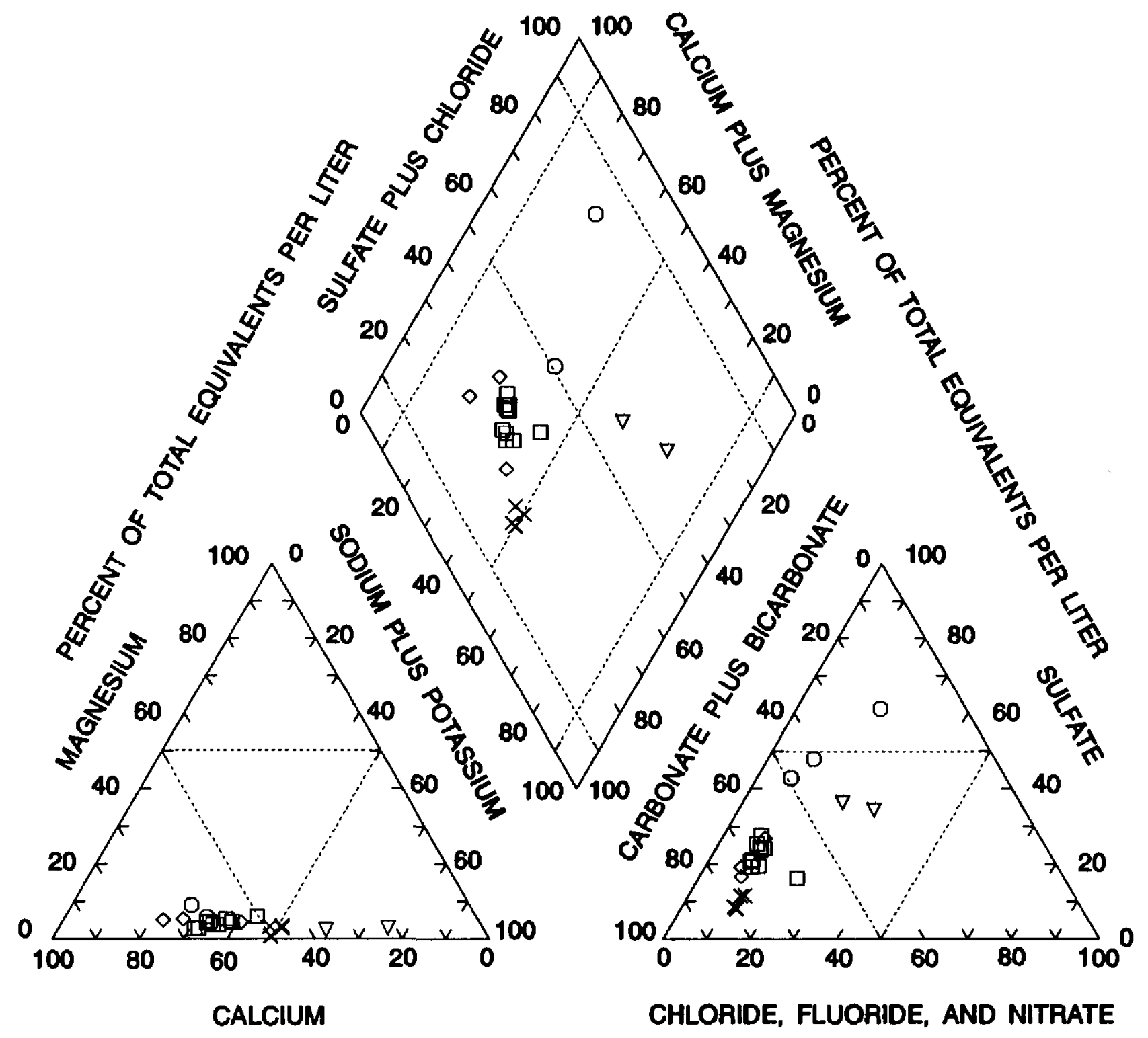

PERCENT OF TOTAL EQUIVALENTS PER LITER

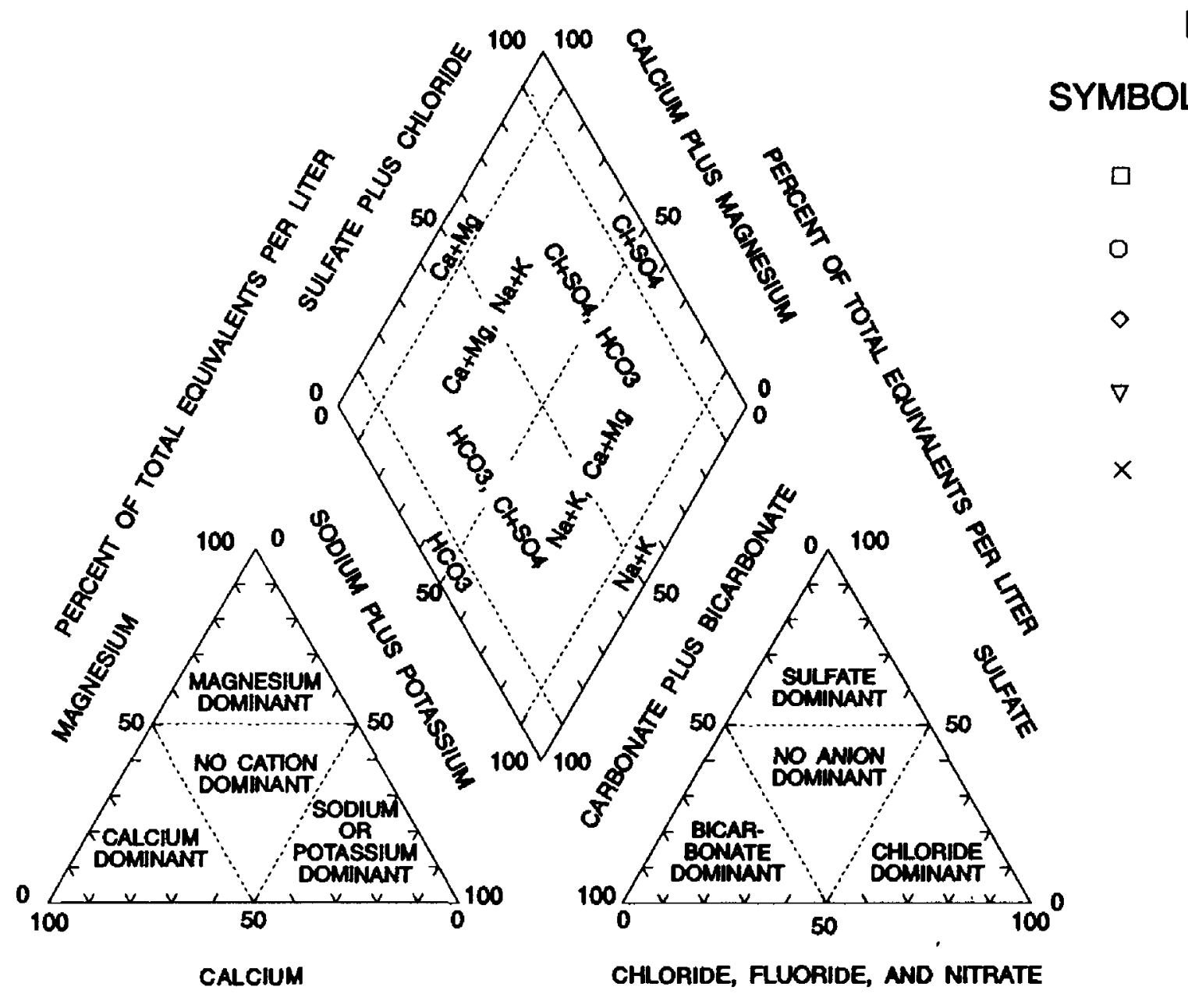

EXPLANATION

SAMPLE IDENTIFICATION AND LOCATION

BK-73-46-701

(Oak Spring)

BK-73-46-702

(Cattail Falls)

BK-73-46-803

(Lower CCC well)

NPS-Big Bend lower

sewage lagoon

BK-73-46-804

(Window Spring)

PERCENT OF TOTAL EQUIVALENTS PER UTER

Flgure 25. Trilinear diagrams showing hydrochemical facies for water samples from The Basin and Oak Spring areas and Cattail Falls, 1954-87, and definitions of hydrochemical facies for a typical classification. 
stantially unaffected by seepage from the sewage lagoon.

Oak Spring ground water has a similar to slightly greater proportion of sodium than does all water sampled from Window Spring except the 1972 Window Spring sample. This indicates that there are differences between the mineralogy or the population of exchangeable cations between The Basin aquifer and Oak Spring aquifer. The pattern of hydrochemical facies and mineral saturation indices discussed above indicates that the water from Oak Spring is derived largely from infiltrating precipitation from west of The Basin and was subsequently modified by rock-water interaction in the Oak Spring aquifer before discharge. This explanation is supported by the lack of variation in major-element concentrations with discharge at Oak Spring (fig. 25) and by the lack of any substantial or verifiable hydrologic connection with The Basin aquifer.

\section{Isotope Geochemistry}

Stable oxygen and hydrogen isotopes were used in this study to indicate the potential source or sources of ground water to Oak Spring. The weight fractionations of the heavy stable isotopes, deuterium and oxygen-18, relative to the more abundant and lighter isotopes, hydrogen- 1 and oxygen-16, can reflect the degree that ground water differs isotopically from modem precipitation (meteoric water). The ratio of the stable isotopes, oxygen-18 to oxygen-16, is computed and reported as del-oxygen-18, as defined by Faure $(1977$, p. 325). The ratio of the stable isotopes, deuterium to hydrogen- 1 , is similarly reported as del-deuterium. A typical, regional relation between deldeuterium and del-oxygen-18 in meteoric water from a similar climatic regime in New Mexico is shown in figure 26 as the regional meteoric-water line. Departures from this relation, such as the enrichment of one isotope relative to the other, can be caused by low-temperature water-rock exchange of isotopes; by evaporation; by mineral precipitation and dissolution, such as through silicate hydrolysis; or by mixing with thermally-modified or saline waters (International Atomic Energy Agency, 1983).

Isotopic data for del-deuterium and del-oxygen18 collected during 1986 generally plot along the regional meteoric-water line as defined by Hoy and Gross (1982) and shown in figure 26. This indicates a precipitation-related origin for all ground water in The
Basin and at Oak Spring without substantial influence by processes mentioned above. The slight shift of the 1986 isotopic data above the meteoric-water line might be caused by differences in local environmental or analytical conditions or by low-temperature water-rock exchange of isotopes. This evidence, however, does not rule out The Basin aquifer as a potential source for some recharge to the Oak Spring aquifer. This potential recharge would occur by way of infiltration of Window Spring discharge through the bed of lower Oak Creek downstream from The Window.

Estimates of ground-water age in this report are made using the activity of tritium in water relative to its activity in precipitation and other potential contributing sources. Tritium is a radioactive isotope of hydrogen with an atomic mass of 3 and a half-life of 12.3 years. It results naturally from the interaction of cosmic rays with the atmosphere and by addition from the solar wind. Synthetic tritium was introduced to the atmosphere in large amounts by the testing of atmospheric thermonuclear devices between 1952 and 1969 (Freeze and Cherry, 1979, p. 37). Concentrations of tritium are reported as a tritium unit, which is 1 atom of tritium per $1 \times 10^{18}$ atoms of hydrogen. Tritium concentrations can be used to classify ground water as:

1. Containing no substantial amounts of water recharged after 1952 if tritium ratios are less than about 2 TU (Freeze and Cherry, 1979, p. 137);

2. Containing a significant proportion of post- 1952 water if tritium ratios are greater than $50 \mathrm{TU}$ (Tyler Coplen, U.S. Geological Survey, written commun., 1986); or

3. Containing some part of their recharge as post1952 water if tritium ratios range between 2 and $50 \mathrm{TU}$.

Results of tritium analyses of water from Oak Spring collected during (1) the winter of 1983 (LopezSepulveda, 1984, p. 31), (2) June 1986, and (3) August 1987 are all much greater than $2 \mathrm{TU}$, indicating that some part of the discharge is composed of post- 1952 recharge (table 4, at end of report). Water from Cattail Falls, the lower CCC well, and Window Spring also had tritium concentrations characteristic of post-1952 recharge water (table 4).

An estimate of the average age of Oak Spring discharge was made by comparing tritium concentrations in local waters sampled during 1986 with tritium 


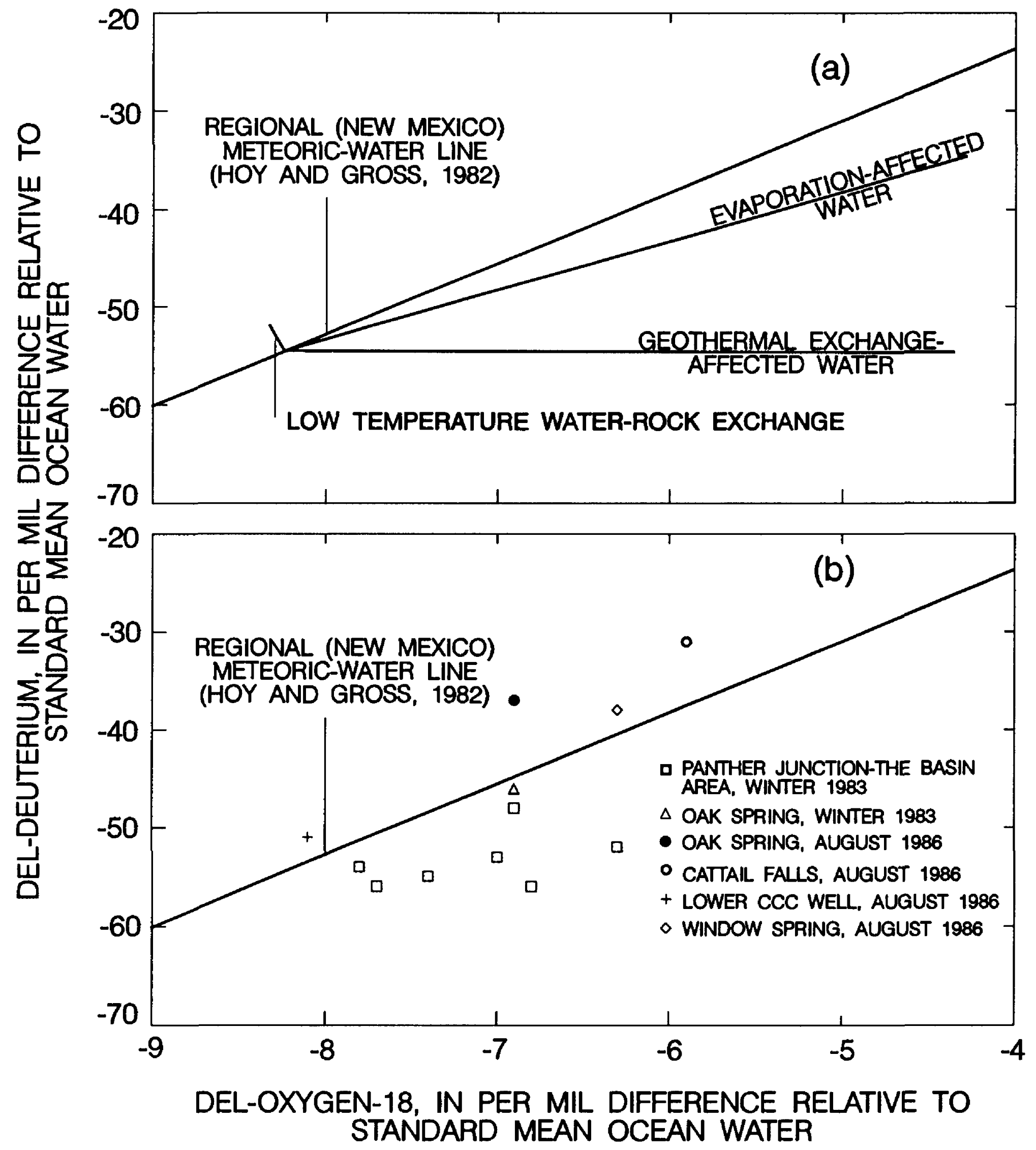

Figure 26. Relation between del-deuterium and del-oxygen-18 (a) among water affected by typical geochemical processes and (b) in water samples from The Basin and Oak Spring areas and Cattail Falls. 
concentrations in regional precipitation, corrected for radioactive decay. Precipitation data from Albuquerque, New Mexico, and Waco, Texas, were used to represent tritium contributions to ground-water recharge from continental air masses (tritium enriched) and coastal air masses (tritium depleted), respectively (fig. 27). Annual average values for tritium in precipitation were computed for those years with three or more analyses. The average tritium concentrations were corrected for radioactive decay to 1986 , using standard decay equations (Faure, 1977). The comparison assumes that recharge from precipitation is not altered by mixing with older or younger waters during groundwater flow.

Decay-corrected, average annual tritium concentrations in precipitation from Waco between 1972 and 1984 (end of record) are similar to those observed in samples from Oak Spring and the other sampled sites (fig. 28). Tritium concentrations in the 1986 samples are generally less than the most recent average annual concentrations in precipitation (1984) from Albuquerque, but agree with the declining trend in tritium concentrations observed in the data. These data indicate that Oak Spring discharge has an average age of less than 14 years. It is probable, however, that some of the Oak Spring discharge is derived from younger, precipitation-related infiltration between the principal locations of recharge and the spring. The heterogeneous distribution of permeable sediments and rock between the recharge and discharge area also offers ample opportunity for dispersive and diffusive mixing of water along the main directions of flow with older ground water. Therefore, the above estimate of average ground-water age is approximate to the unknown extent that the assumptions of piston flow are violated.

The ratio of the stable isotopes nitrogen- 15 to nitrogen-14 in nitrate (del-nitrogen-15) has been used to distinguish the source of nitrate nitrogen in ground water (Kreitler, 1975; Gormly and Spaulding, 1979). The primary sources of nitrate to ground water in The Basin area are: (1) Soil nitrogen (del-nitrogen- $15=+2$ to +9 per mil), and (2) wastes from sewage or animals (del-nitrogen-15 $=+10$ to +23 per mil). The del-nitrogen-15 values cited above are useful for qualitative comparison and have been found accurate for studies conducted in Runnels County, Texas (Kreitler, 1975), and in Nebraska (Gormly and Spaulding, 1979), but also have been found to overlap in other studies (Tyler Coplen, U.S. Geological Survey, written commun., 1986). The del-nitrogen-15 ratios determined for Oak
Spring (+5.5 per mil) and Window Spring (+5.2 per mil) indicate that the nitrate in ground water at these locations originates mostly from the decomposition of soil organic matter and not primarily from animal or human wastes.

\section{Quality of The Basin and Oak Spring Ground Water}

The quality of water from sites sampled during this study was evaluated by comparing the results of the chemical analysis (table 4, at end of report) to the regulations enforced by the U.S. Environmental Protection Agency (USEPA) for public water systems (table 5; U.S. Environmental Protection Agency, 1985, 1986a, 1986b, 1990). The only dissolved constituent to consistently approach its maximum contaminant level ( $4 \mathrm{mg} / \mathrm{L}$ ) was fluoride. The only location, however, where fluoride concentrations did not equal or exceed the USEPA secondary maximum contaminant level (2 $\mathrm{mg} / \mathrm{L}$ ) was Cattail Falls during the 1966,1986 , and 1987 samplings (table 4). The activity of gross alpha radiation in one water sample from Oak Spring, 14.3 $\mathrm{pCi} / \mathrm{L}$, was slightly less than the maximum activity of $15 \mathrm{pCi} / \mathrm{L}$ permitted in drinking water by the Texas Department of Health (Texas Register, 1977). The presence of fluoride and gross-alpha radiation in ground water is related to the aquifer mineralogy and not to human activities in the park.

The 1989 water sample collected from Cattail Falls contained $510 \mathrm{mg} / \mathrm{L}$ of dissolved solids and exceeded the secondary maximum contaminant level for public water supplies by $10 \mathrm{mg} / \mathrm{L}$. The $1989 \mathrm{sam}$ ple, however, previously has been determined not to be representative of ground-water quality in the watershed above Cattail Falls because of the small discharge reaching the pool at the time of sampling. None of the remaining constituents approached USEPA maximum contaminant levels for drinking water.

\section{Effect of The Basin Activities on Ground- Water Quality}

Several constituents of ground water were analyzed for anthropogenic pollutants. Potential anthropogenic pollutants from human activities in The Basin can be grouped into three categories: (1) Nutrient species, such as nitrate and phosphorus; anionic surfac- 


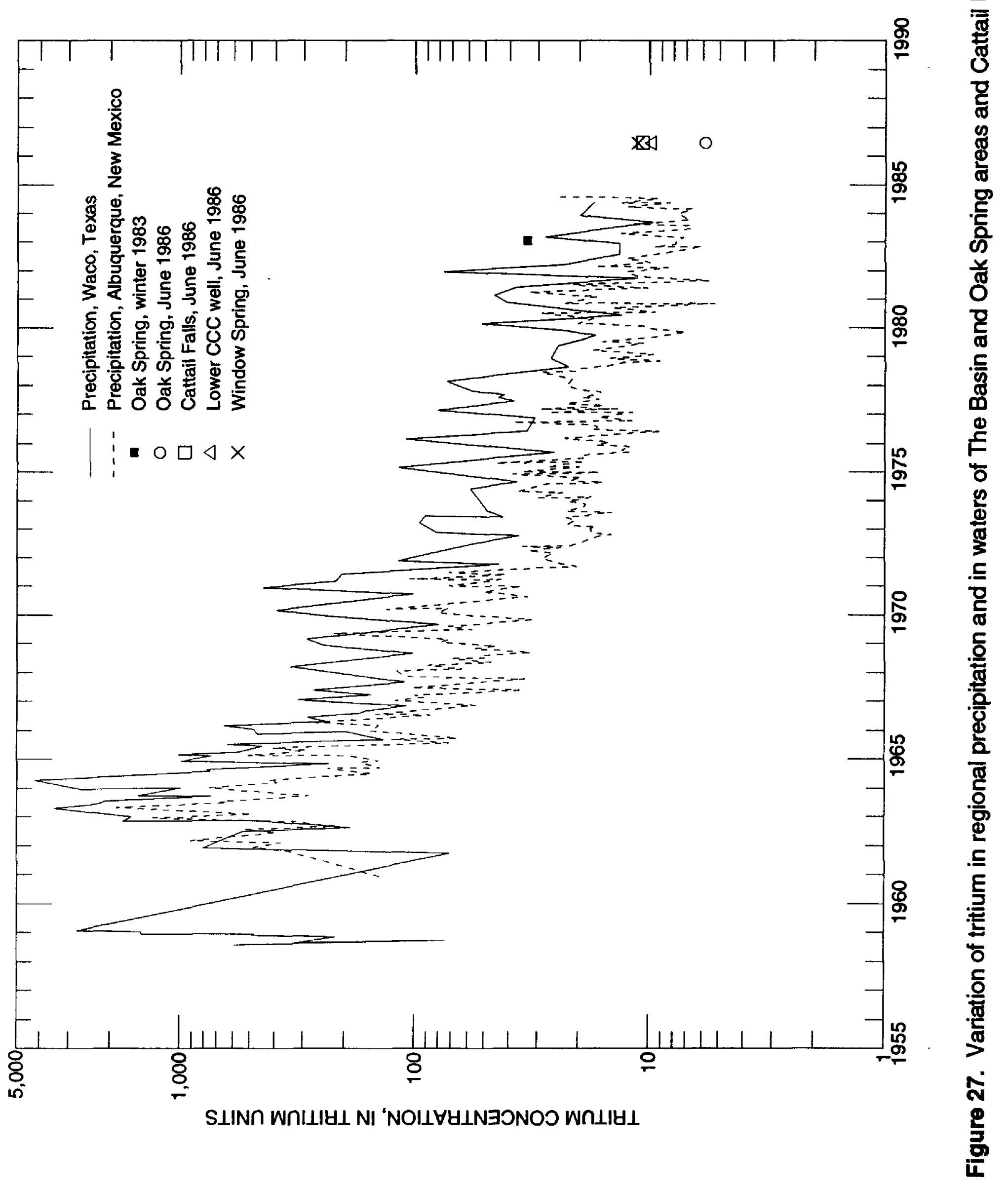




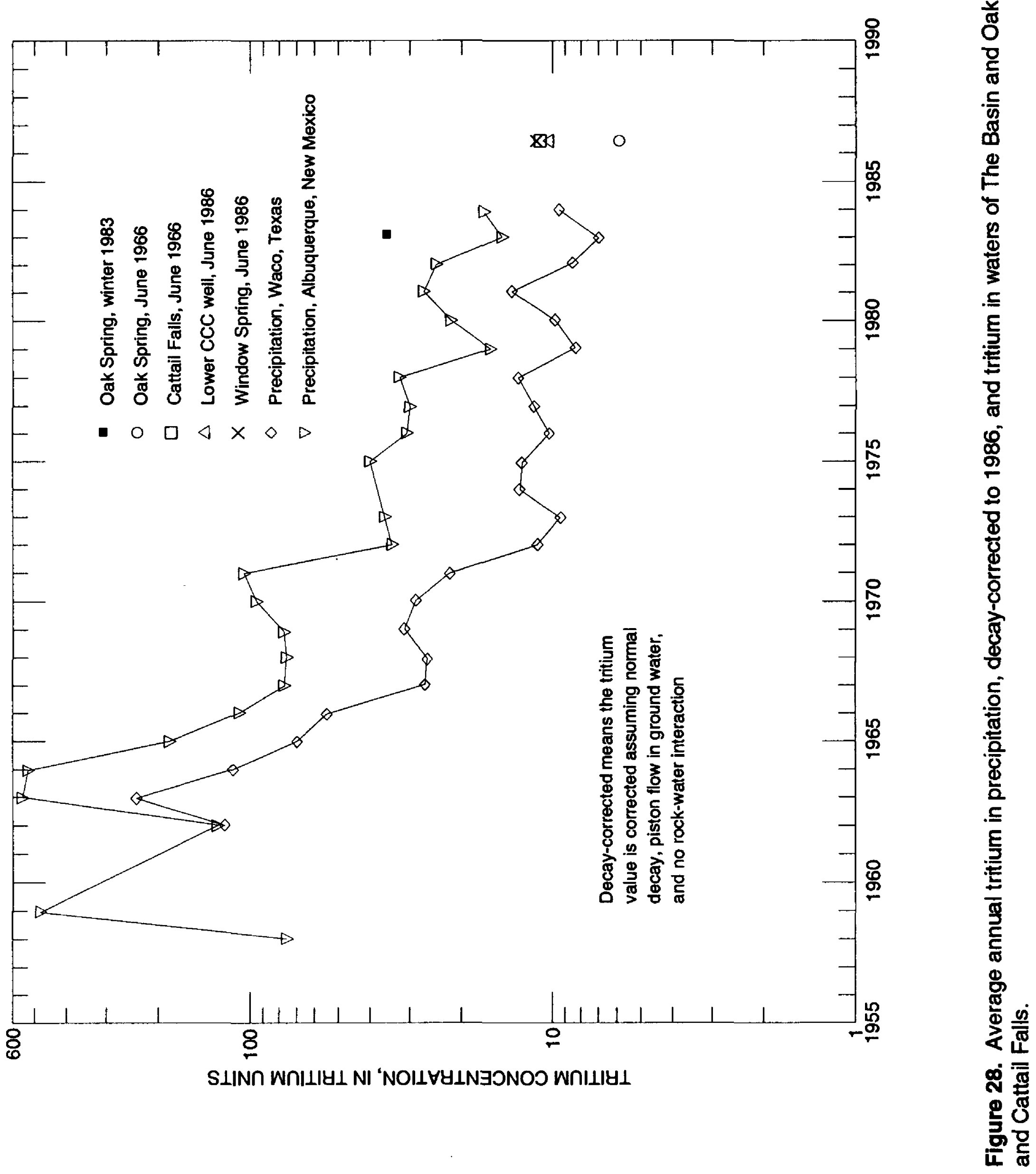


Table 5. Summary of maximum contaminant levels and secondary maximum contaminant levels for selected water-quality properties and constituents for public water systems

[mg/L, milligrams per liter; --, not detected; $\mu \mathrm{g} / \mathrm{L}$, micrograms per liter; $\mathrm{pCi} / \mathrm{L}$, picocuries per liter]

\begin{tabular}{|c|c|c|}
\hline Property or constituent ${ }^{2}$ & Maximum contaminant level ${ }^{3}$ & $\begin{array}{l}\text { Secondary maximum } \\
\text { contaminant level }\end{array}$ \\
\hline \multicolumn{3}{|c|}{ Inorganic elements and related properties $(\mathrm{mg} / \mathrm{L})$} \\
\hline pH (standard units) & -- & $6.5-8.5$ \\
\hline Dissolved solids & -- & 500 \\
\hline Chloride (Cl) & -- & 250 \\
\hline Fluoride $(\mathrm{F})^{5}$ & 4 & 2.0 \\
\hline Nitrate (as $\mathbf{N}$ ) & 10 & -- \\
\hline Sulfate $\left(\mathrm{SO}_{4}\right)$ & -- & 250 \\
\hline \multicolumn{3}{|c|}{ Trace elements $(\mu \mathrm{g} / \mathrm{L})$} \\
\hline Arsenic (As) & 50 & -- \\
\hline Barium (Ba) & 1,000 & -- \\
\hline Cadmium (Cd) & 10 & -- \\
\hline Chromium $(\mathrm{Cr})$ & 50 & -- \\
\hline Copper $(\mathrm{Cu})$ & -- & 1,000 \\
\hline Iron $(\mathrm{Fe})$ & -- & 300 \\
\hline Lead $(\mathrm{Pb})$ & 50 & -- \\
\hline Manganese (Mn) & -- & 50 \\
\hline Mercury $(\mathrm{Hg})$ & 2 & -- \\
\hline Selenium (Se) & 10 & -- \\
\hline Silver (Ag) & 50 & -- \\
\hline Zinc (Zn) & -- & 5,000 \\
\hline \multicolumn{3}{|c|}{ Organic compounds $(\mu \mathrm{g} / \mathrm{L})$} \\
\hline \multicolumn{3}{|l|}{ Chlorinated hydrocarbons } \\
\hline Endrin & .2 & -- \\
\hline Lindane & 4 & -- \\
\hline Methoxychlor & 100 & -- \\
\hline Toxaphene & 5 & - \\
\hline
\end{tabular}

Footnotes at end of table. 
Table 5. Summary of maximum contaminant levels and secondary maximum contaminant levels for selected water-quality properties and constituents for public water systems ${ }^{1}-$-Continued

\section{Property or constituent ${ }^{2} \quad$ Maximum contaminant level ${ }^{3} \quad$ Secondary maximum contaminant level ${ }^{4}$}

Organic compounds $(\mu \mathrm{g} / \mathrm{L})$--Continued

Chlorophenoxys

2,4-D

Silvex

Trichloroethylene

Carbon tetrachloride

Vinyl chloride

1,2-Dichloroethane

Benzene

1,1-Dichloroethylene

1,1,1-Trichloroethane

p-Dichlorobenzene

Gross alpha radiation

Radium-226
100

10

Volatile organic compounds $(\mu \mathrm{g} / \mathrm{L})^{6}$

.005

.005

Radiochemical activities (pCi/L)
.001

.005

.005

.007

.20

.75

$-$

$-$

\section{5}

5

${ }^{1}$ Public water system.--A system for the provision of piped water to the public for human consumption, if such system has at least 15 service connections or regularly serves at least 25 individuals daily at least 60 days out of the year.

${ }^{2}$ Constituent.--Any physical, chemical, biological, or radiological substance or matter in water.

${ }^{3}$ Maximum contaminant level.--The maximum permissible level of a contaminant in water which is delivered to the free-flowing outlet of the ultimate user of a public water system. Maximum contaminant levels are those levels set by the U.S. Environmental Protection Agency (1986a) in the National Primary Drinking Water Regulations. These regulations deal with contaminants that may have a significant direct impact on the health of the consumer and are enforceable by Federal law.

${ }^{4}$ Secondary maximum contaminant level.--The advisable maximum level of a contaminant in water which is delivered to the freeflowing outlet of the ultimate user of a public water system. Secondary maximum contaminant levels are those levels proposed by the U.S. Environmental Protection Agency (1986b) in the National Secondary Drinking Water Regulations. These regulations deal with contaminants that may not have a significant direct impact on the health of the consumer, but their presence in excessive quantities may affect the aesthetic qualities of the water and may discourage the use of a drinking-water supply by the public.

${ }^{5}$ Fluoride.--Revised (U.S. Environmental Protection Agency, 1990).

${ }^{6}$ Proposed maximum contaminant levels (U.S. Environmental Protection Agency, 1985).--The maximum contaminant level for tetrachloroethylene will be proposed later.

tants from detergents measured as methylene blue active substances (MBAS); boron; fecal-coliform and fecal-streptococcal bacteria; and enteric viruses and Protozoan parasites (Giardia lamblia), which are asso- ciated with domestic wastewater and human waste (Leblanc, 1982; Joan Rose, University of Arizona, written commun., 1988); (2) pesticides applied within The Basin; and (3) volatile and semivolatile organic 
compounds, such as toluene and xylene, associated with the first two sources and with the use of fossil fuels. Concem about the impact of human activities within The Basin on the quality of Oak Spring discharge arose principally because the pesticide mirex was detected in a 1976 sample from Oak Spring.

MBAS concentrations indicated a potential association between water quality from the lower sewage lagoon, Oak Spring, and Window Spring. The MBAS concentrations from Oak Spring and Window Spring in 1986 were greater than the concentration in one sample from Cattail Falls and substantially less than the concentrations in two samples from the lower sewage lagoon. The MBAS concentrations from all sites except the lower sewage lagoon were less than or equal to 2.5 times the detection threshold of $0.02 \mathrm{mg} / \mathrm{L}$ for the analytical method. However, no detergent-related compounds such as linear alkyl benzenes, alkyl phenols, or benzoquinones as described by Barber (1985) were determined in the closed-loop stripping (CLS) analysis of water from the lower sewage lagoon (table 6). The MBAS concentration range of 0.02 to $0.05 \mathrm{mg} / \mathrm{L}$ in the non-lagoon water quality was described as representing background conditions by Barber (1985) in an investigation of detergent compounds in a glacial sand aquifer near Cape Cod, Massachusetts. Potential natural and human-related interferences with MBAS determinations include chlorides, nitrates, and organic sulfonates, sulfates, carboxylates, and phenols (American Public Health Association, 1985). These data indicate that MBAS concentrations determined at the sampled locations might be from natural interferences or from sources other than the sewage lagoons.

Boron concentrations indicated a potential association between water quality from the lower sewage lagoon, Oak Spring, the lower CCC well, and Window Spring. Boron concentrations from Oak Spring, the lower CCC well, and Window Spring were greater than the concentration in one sample from Cattail Falls and substantially less than the concentrations in two samples from the lower sewage lagoon (table 4, at end of report). The concentrations of boron determined in all water samples except those of the lower sewage lagoon are also with the range of less than "a few tenths of a milligram per liter" that is typical of many natural ground and surface waters (Hem, 1985). Boron also is typically a constituent of intrusive and extrusive lithologies, including granites, pegmatites, and basalts (Hem, 1985). These lithologies are all represented in The Basin and Oak Spring aquifers either as primary rock or by their provenance as sediments. Therefore, it could not be determined whether boron concentrations in water from these sites originated from humanaffected or natural sources.

Total-coliform, fecal-coliform, and fecal-streptococcal bacteria were found in densities of less than 10 cols./100 mL in the summer 1986 sample from Oak Spring but were not detected in the spring 1988 sample (table 7). This inconsistency in analytical results could be from bacteria that were inadvertently introduced into the sample by the 1986 sampling procedure. All other sites in the spring 1988 sampling except The Basin campground picnic site 44 contained small but measurable counts of total-coliform and fecal-streptococcal bacteria and $1 \mathrm{col} . / 100 \mathrm{~mL}$ or nondetectable counts of fecal-coliform bacteria. The fecal-streptococcal bacteria counts of 200 cols. $/ 100 \mathrm{~mL}$ at the lower $\mathrm{CCC}$ well indicate the presence of nonhuman, animal waste in the water. Field observations indicate this might originate from rodent nesting activity in the well. Fecal-streptococcal and fecal-coliform counts at Cattail Falls, a pristine area, are similar to those observed in the sample from Window Spring, an area receiving considerable human and animal activity. This similarity, based on one observation at each site, indicates a tentative hypothesis that the bacterial water quality at Window Spring is not degraded by human activities in The Basin.

No enteric viruses or Giardia lamblia were determined in any of the samples collected from the park (table 7). This evidence corroborates the lack of bacterial species and indicates no effect by human activity on ground-water and surface-water quality in The Basin area.

The second category of anthropogenic pollutants examined by this study are pesticides that have been applied in the areas of The Basin and near Oak Spring. Pesticides such as mirex and malathion previously have been used as the need arose to control ants and mosquitoes in selected locations near trails and campgrounds (Tom Alex, National Park Service, oral commun., 1988). Water from Oak Spring was sampled during June 1986 and August 1987 and analyzed for organochlorine and organophosphorus insecticides and chlorphenoxy-acid herbicides. The accumulated sediment from the bottom of the concrete receiving box for discharge from Oak Spring was collected and analyzed for extractable organochlorine insecticides. The sediment analysis was intended to determine whether small concentrations of the hydrophobic organochlorine 
Table 6. Concentrations of volatile and semivolatile organic compounds in water samples extracted by closedloop stripping, The Basin and Oak Spring areas, August 1987

[Concentrations in nanograms per liter; CCC, Civilian Conservation Corps; --, not detected]

\begin{tabular}{|c|c|c|c|c|c|c|}
\hline \multirow[b]{2}{*}{ Compound } & \multicolumn{6}{|c|}{ Local identifier, sample Identlifier, and date } \\
\hline & $\begin{array}{c}\text { BK-73-46-701 } \\
\text { Oak Spring } \\
\text { BB87-1 } \\
08 / 23 / 87\end{array}$ & $\begin{array}{c}\text { BK-73-46-701 } \\
\text { Oak Spring } \\
\text { BB87-1.2 } \\
08 / 23 / 87\end{array}$ & $\begin{array}{c}\text { BK-73-46-701 } \\
\text { Oak Spring } \\
\text { BB87-5 } \\
08 / 25 / 87\end{array}$ & $\begin{array}{c}\text { BK-73-46-804 } \\
\text { Window } \\
\text { Spring } \\
\text { BB87-3 } \\
08 / 24 / 87\end{array}$ & $\begin{array}{c}\text { BK-73-46-803 } \\
\text { Lower CCC } \\
\text { well BB87-4 } \\
08 / 24 / 87\end{array}$ & $\begin{array}{l}\text { Lower } \\
\text { sewage } \\
\text { lagoon } \\
\text { BB87-6 } \\
08 / 26 / 87\end{array}$ \\
\hline Methyl benzene (toluene) & 50 & -- & -- & -- & 10 & 110 \\
\hline Ethyl benzene & 10 & -- & -- & -- & -- & -- \\
\hline Dimethyl benzene (xylene) & 30 & -- & -- & -- & -- & 60 \\
\hline Trimethyl benzene & -- & -- & -- & -- & -- & 30 \\
\hline Nonanol & 20 & -- & -- & -- & -- & -- \\
\hline Decanol & 50 & -- & -- & -- & -- & -- \\
\hline Tridecane & 40 & -- & -- & -- & -- & -- \\
\hline Tetradecane & 20 & -- & -. & -- & -- & -- \\
\hline $\begin{array}{l}\text { 2,6-bis (1,1-dimethylethyl)-2,5- } \\
\text { cyclohexadiene-1,4-dione }\end{array}$ & -- & -- & 30 & -- & -- & -- \\
\hline 1-dodecanol & - & - & -- & - & -- & 60 \\
\hline Heptadecane & -- & -- & -- & -- & -- & 200 \\
\hline $\begin{array}{l}\text { Methyl N-(2,4-dimethyl-1- } \\
\text { napthyl) carbamate }\end{array}$ & -- & -- & -- & -- & 20 & -. \\
\hline
\end{tabular}

insecticides were currently or previously present in spring discharge and had accumulated in the sediment. Results of these analyses indicated no incidence of these compounds in water or sediment samples that were at or greater than their analytical detection thresholds.

The third category of anthropogenic pollutants analyzed in water are volatile and semivolatile organic compounds. The only volatile organic compound detected in water samples in concentrations above the analytical detection threshold of $0.2 \mathrm{mg} / \mathrm{L}$ was chloroform $(2.9 \mathrm{mg} / \mathrm{L})$ in a sample from the lower sewage lagoon in The Basin (table 4). Chloroform is a common byproduct of the chlorination of nutrient and organic carbon rich wastewater. Semivolatile organic compounds were detected in a sample collected in June 1986 from the lower CCC well in The Basin aquifer. Compounds tentatively identified from the sample include hexadecanoic acid $(3 \mu \mathrm{g} / \mathrm{L})$ and 3-ethyl-4methyl-2,5-furandione $(0.8 \mu \mathrm{g} / \mathrm{L})$, and six unknown alkane compounds (total concentration: $43 \mu \mathrm{g} / \mathrm{L}$ ). The 3-ethyl-4-methyl-2,5-furandione might be synthetic residue from the use of the pesticide malathion for mosquito control in The Basin. The other compounds might have originated as contaminants from the submersible pump and garden hose used for collection of this specific sample.

Volatile and semivolatile organic compounds identified in CLS extracts from The Basin area water samples are shown in table 6. Several monoaromatic compounds indicative of human activity, such as methyl benzene (toluene), ethyl benzene, and an unidentified isomer of dimethyl benzene (xylene) were detected in the first CLS sample (August 23, 1987) collected from Oak Spring but not in a duplicate sample or in a sample collected 2 days later. Toluene and xylene 
Table 7. Results of viral and microbial analyses of water samples, The Basin and Oak Spring areas and Cattail Falls, June 1986 and March 1988

[L, liters; MPN, most probable number; org/L.e., number of organisms per volume in liters of filter elutriate analyzed; cols./100 mL, colonies per 100 milliliters of filtered sample; $\mu \mathrm{m}-\mathrm{MF}$, micrometer membrane; --, not determined; <, less than]

\begin{tabular}{|c|c|c|c|c|c|c|c|c|}
\hline \multirow[b]{2}{*}{ Local Identifier } & \multicolumn{3}{|c|}{ Vlruses } & \multicolumn{2}{|c|}{ Protozoan parasites } & \multicolumn{3}{|c|}{ Bacteria } \\
\hline & $\begin{array}{l}\text { Flltered } \\
\text { volume } \\
\text { (L) }\end{array}$ & $\begin{array}{c}\text { Enterlc } \\
\text { viruse } \\
\text { (MPN) } \\
\text { (orgh.e.) }\end{array}$ & $\begin{array}{l}\text { Hepatlis } \\
\text { (org/Le.) }\end{array}$ & $\begin{array}{l}\text { Filtered } \\
\text { volume } \\
\text { (L) }\end{array}$ & $\begin{array}{c}\text { Glardla } \\
\text { lamblla } \\
\text { (org/Le.) }\end{array}$ & $\begin{array}{c}\text { Collforms, } \\
\text { total } \\
\text { (cols J } \\
100 \mathrm{~mL})\end{array}$ & $\begin{array}{c}\text { Collforms, } \\
\text { focal, 0.7 } \\
\mu \mathrm{m}-M F \\
\text { (cols } \\
100 \mathrm{~mL} \text { ) }\end{array}$ & $\begin{array}{c}\text { Strep- } \\
\text { tococcl, fecal, } \\
\text { KF-agar } \\
\text { (cols } / 100 \mathrm{~mL} \text { ) }\end{array}$ \\
\hline \multicolumn{9}{|c|}{ June 1986} \\
\hline $\begin{array}{l}\text { BK-73-46-701 } \\
\text { (Oak Spring) }\end{array}$ & -- & -- & -- & -- & -- & 6 & 8 & 9 \\
\hline \multicolumn{9}{|c|}{ March 1988} \\
\hline & $\begin{array}{l}1,013 \\
1,024\end{array}$ & $\begin{array}{l}0 / 351 \\
0 / 308\end{array}$ & $\begin{array}{l}0 / 195 \\
0 / 171\end{array}$ & 114 & $0 / 57$ & $<1$ & $<1$ & $<1$ \\
\hline $\begin{array}{l}\text { BK-73-46-702 } \\
\text { (Cattail Falls) }\end{array}$ & 1,014 & $0 / 40$ & $0 / 169$ & 113 & $0 / 102$ & 380 & 1 & 22 \\
\hline $\begin{array}{l}\text { BK-73-46-803 } \\
\text { (Lower } \\
\text { Civilian } \\
\text { Conservation } \\
\text { Corps well) }\end{array}$ & 1,017 & $0 / 257$ & $0 / 143$ & - & -- & 25 & $<1$ & 200 \\
\hline $\begin{array}{l}\text { BK-73-46-804 } \\
\text { (Window } \\
\text { Spring) }\end{array}$ & 1,021 & $0 / 323$ & $0 / 179$ & 151 & $0 / 75.6$ & 19 & 1 & 40 \\
\hline $\begin{array}{l}\text { The Basin } \\
\text { Campground } \\
\text { water supply, } \\
\text { picnic site } 44 \\
\text { (chlorinated) }\end{array}$ & 1,036 & $0 / 243$ & $0 / 134$ & -- & -- & $<1$ & $<1$ & $<1$ \\
\hline
\end{tabular}

also were detected in the sample collected from the lower sewage lagoon. Because of the poor reproducibility between samples, however, these results do not indicate a definite connection between waste-disposal practices in The Basin and ground-water quality at Oak Spring. Leaching of trace concentrations of toluene, ethyl benzene, and xylene from bitumen-bearing shale and shaly limestone has been demonstrated to be a possible natural source of these compounds in ground water (Slaine and Barker, 1990). Carbonaceous shale or clay, commonly associated with lignite, is widespread throughout the Aguja Formation in the Big Bend region (Maxwell, 1967, p. 86). The resemblance of sediments of the Oak Spring aquifer to those of the
Aguja Formation indicates there could be a natural origin for the intermittently detected volatile and semivolatile organic compounds in Oak Spring discharge.

\section{DISCUSSION AND CONCLUSIONS}

Oak Spring is a dependable source of varying amounts of water. Its permanency is indicated by the luxuriant "green belt" of vegetation associated with the spring. This dense plant community stands in stark contrast to the adjacent less-vegetated area. The plants are able to thrive only where a perennial supply of ground water is present. 
Oak Spring, which is now instrumented with a continuous water-level recorder, had a recorded high flow of $167 \mathrm{gal} / \mathrm{min}$ on December 12, 1986. This flow resulted from record-high precipitation that year. It is reasonable to expect that spring flow exceeded that rate at some time earlier in 1986, because flow was already receding when the recorder went into operation on December 12, 1986. A recorded low flow of $22.4 \mathrm{gal} /$ min was reached December $2-4,1989$, following 20 out of 26 months of below-normal precipitation. At the end of the period of record on December 7, 1989, the flow had recovered only slightly to $23.8 \mathrm{gal} / \mathrm{min}$. Prior to the present study, only miscellaneous spring-flow measurements were made. Of the 29 measurements made from 1953 to 1972 , the flow ranged from 6 to $80 \mathrm{gal} /$ min. The low-flow rate was first noted in 1956 following 6 years of below-normal precipitation. Because of the close relation between spring flow and precipitation, flow rates of less than $6 \mathrm{gal} / \mathrm{min}$ and more than $167 \mathrm{gal} / \mathrm{min}$ could occur in the future. The water-level recorder at Oak Spring will provide flow data necessary to continuously monitor the spring's performance.

Test drilling revealed that the aquifer in the immediate vicinity of Oak Spring is a sand bed 5- $\mathrm{ft}$ thick (Oak Spring aquifer) that is hydraulically confined above and below by mostly thick, compact clay. Furthermore, test drilling and seismic-refraction surveys indicated that the alluvium and colluvium (overburden) above the bedrock is unsaturated, at least in the test borings that fully penetrated the overburden.

Possible faulting in the Oak Spring area is evidenced by the deflection of the regionally westwardmoving water in the aquifer toward the north bank of Oak Creek Canyon where Oak Spring issues. Sharp demarcations in the type and density of vegetation east and west of the spring may be boundaries of faults concealed by the overburden. The very steeply dipping bedding planes in the clay in monitoring well TB-7 are further evidence of possible faulting in the immediate area.

The Oak Spring aquifer does not extend eastward into The Basin, but rather is bounded by the igneous intrusion at The Window. For this reason, water must enter the Oak Spring aquifer outside The Basin. Information collected from drilling and from hydrogeologic observations indicates that the water discharging from Oak Spring originates as precipitation in the Oak Spring area west of The Basin with possibly a component originating as discharge from The Basin. The rhyolite boulder field with its numerous crevices, including the talus apron from Vernon Bailey Peak (on the east side of the Oak Spring area), is an effective receptacle for rapid recharge of precipitation and storage of ground water. This water could then be efficiently routed into the underlying Oak Spring aquifer at places where the aquifer is in direct hydraulic connection with the boulder field and talus apron. The most favorable area for such recharge probably is between monitoring well TB-7 and the steep slope of Vernon Bailey Peak to the east, an average distance of about $1,500 \mathrm{ft}$ from Oak Spring. From here the general direction of ground-water flow is probably westward toward Oak Spring.

Interpretation of water-chemistry data, including hydrochemical facies and isotopic data, also indicates that ground-water discharge from Oak Spring originates principally from recent precipitation in the Oak Spring area. The hydrochemical facies for Oak Spring are intermediate in composition between those for Cattail Falls and Window Spring. Oxygen-18 and deuterium data indicate that Oak Spring discharge originated as meteoric (atmospheric) water. This indicates an origin for Oak Spring discharge as meteoric water that has been altered to its present composition by rock-water interaction. Tritium isotopic data show that Oak Spring discharge is modern, indicating an average date of recharge within the last 14 years. This relatively young average age of ground water estimated from tritium data, the magnitude of discharge observed from Oak Spring, and the generally small amounts of precipitation in the area indicate that flow through the aquifer is rapid. If the most favorable area for recharge is an average distance of $1,500 \mathrm{ft}$ from Oak Spring as postulated, and if the average age of Oak Spring water is less than 14 years as indicated, then the minimum rate of water movement in the Oak Spring aquifer is about $100 \mathrm{ft}$ per year.

Water quality of Oak Spring discharge was evaluated by comparing it to public water-system standards of the U.S. Environmental Protection Agency and the Texas Department of Health. Fluoride concentrations in all water samples, except those from Cattail Falls, exceed the U.S. Environmental Protection Agency secondary maximum contaminant level of $2 \mathrm{mg} / \mathrm{L}$, an aesthetic standard for water quality. All remaining constituents that are subject to regulations did not exceed public water-system standards.

Presence of fecal-coliform and fecal-streptococcal bacteria in a June 1986 sample collected from Oak Spring indicates that human or animal sources may 
occasionally affect water quality at Oak Spring. Sufficient evidence was not available to verify the persistence of such bacteria in Oak Spring discharge or to locate their source. Xylene and toluene were detected in one of three water samples collected from Oak Spring and in a water sample collected from the sewage lagoon. However, lack of reproducibility of analyses of the Oak Spring water samples prevented the determination of a connection between waste-disposal practices in The Basin and water quality at Oak Spring. Concentrations of boron, nitrate, and MBAS were not substantially different from background levels among Window Spring, Cattail Falls, and Oak Spring. On the basis of interpretation of water analyses for Cattail Falls and the relative inaccessibility of the drainage basin above Cattail Falls to park visitors, the water is considered to be virtually unaffected by human activity.

In addition to the dischange of Window Pouroff as a potential source of recharge, some ground water in The Basin may be moving westward through fractures and joints in the igneous intrusive rock at and near The Window. Once through the igneous rock, such water could be available as a fairly constant source of recharge to the Oak Spring aquifer. This assumes that the aquifer is present and receptive to such recharge in those areas where the water is available.

Varying amounts of surface water as direct runoff and ground water as spring flow from Window Spring are discharged from The Basin at The Window and may possibly be sources of recharge to the Oak Spring aquifer. Such water goes over Window Pouroff dropping about $150 \mathrm{ft}$ to the head of lower Oak Creek Canyon at a level $160 \mathrm{ft}$ above Oak Spring. The average flow of from 5 to $10 \mathrm{gal} / \mathrm{min}$ over Window Pouroff, which is much smaller at most times than the average flow of Oak Spring, quickly disappears into the channel gravel and becomes underflow. The ultimate destination of this water is not known, but it is possible that some recharge to the Oak Spring aquifer can occur if the aquifer intersects the channel at an elevation higher than the spring and if the aquifer is receptive to recharge at this point.

The absence of saturation in the Quaternary alluvial and colluvial fill material at and near the sewage lagoons in The Basin area of Big Bend National Park, Texas, has been established. Test drilling through the fill material to bedrock has shown that the fill in the vicinity of the lagoons was non water bearing. Test borings TB-2 and TB-3, which were drilled adjacent to and downslope from the large lower lagoon alongside a channel of upper Oak Creek, encountered no saturation and little or no moisture. Results from a seismic-refraction survey also indicate that there was not a distinct indication of a saturated alluvial layer above the bedrock. Because no saturation was detected by test drilling in the alluvium and colluvium close to the lagoons, leakage from the lagoons, which were installed in 1963 , is judged to be insignificant. Thus, no pollution plume was identified.

A small but fairly consistent quantity of ground water is discharged by Window Spring in the upper Oak Creek channel near Window Pouroff. The water may be from (1) a locally saturated part of the extensive alluvial and colluvial fill material in The Basin intersecting the land surface near the contact of fill material with the outcrop of igneous intrusive rocks, or (2) spring flow entering upper Oak Creek from the more pristine terrain in the Ward Mountain area, or (3) saturation in the jointed igneous intrusive rocks near The Window. The quality of this water from Window Spring, which feeds lower Oak Creek at the base of Window Pouroff, has been found to contain constituents that could be related to human activity at background levels.

The potential for contamination of Oak Spring from activities related to present development in The Basin and Oak Spring areas is considered to be negligible. The Oak Spring area, where most of the recharge occurs, is only sparsely developed and is not easily accessible to many visitors. Chemical and microbial indicators of human activity in water analyses from Oak Spring were either not detected, not persistent among two or three samples, or present at background concentrations. Even activities in The Basin, which contains the sewage lagoons and which is the center of tourist activity, have not had any important impact on the shallow ground water in The Basin at two key check points--the lower $\mathrm{CCC}$ well and Window Spring. If contamination was originating from human activities in The Basin, the quality of these shallow-water sources could be susceptible to degradation. This is because the $\mathrm{CCC}$ well is adjacent to and downslope from the large campground, and Window Spring, which is at the only surface-drainage outlet of The Basin, releases ground water that has circulated within various areas of The Basin watershed.

Contamination of ground water in The Basin and to Oak Spring by sewage-pond leakage, though negligible, is possible when hypothetical assumptions are made. If the sewage ponds should leak substantially, 
then such effluent would infiltrate the alluvium and colluvium and move downgradient, ultimately to zones of saturation. From here, movement would be toward the west and probably eventually through The Window. If the Oak Spring aquifer west of The Basin (at levels above Oak Spring) could come in contact with water coming out of The Basin, then water carrying the effluent could recharge the aquifer and eventually could be discharged at Oak Spring. However, because of the filtration provided by the porous media, biological contamination of any ground water from the sewage effluent is considered unlikely. The concentration of dissolved major constituents and minor elements in any possible sewage-pond leakage would be expected to be much reduced by dilution initially from any naturally occurring water in the fill material and later by water in the Oak Spring aquifer.

Any concern about possible pollution of Oak Spring from catastrophic flooding that may cause the sewage-lagoon levees to fail is considered groundless. In such an unlikely event, only a relatively small volume of effluent, probably less than 10 acre- $\mathrm{ft}$, would be incorporated into an enormous volume of runoff. Dilution would quickly render any immediate contamination insignificant. Even if the Oak Spring aquifer were to be recharged by such floodwater, the floodwater would be unlikely to have any detectable biological traces of sewage effluent because of filtration provided by the aquifer. Also, the potential for contamination by any chemical constituents should be minimal because of dilution by floodwaters and the very short time of exposure to the Oak Spring aquifer as the floodwave passed down the channel.

\section{ADDITIONAL DATA COLLECTION AND STUDY}

The hydrogeologic conclusions drawn from this study were based on the availability and analysis of preexisting data and on new data acquired within the scope of the study. Nevertheless, as additional information becomes available either through continued monitoring of existing hydrologic sites or through acquisition of data from new sites, some conclusions may be strengthened or modified and possibly new conclusions drawn.

Not enough information is known about the water budget of The Basin to account for the amount of recharge and discharge of surface and ground water in this area and for the various directions of ground-water movement. In this regard, a determination of the hydrogeologic framework would be a basic need. Additional test drilling, coupled with appropriate geophysical surveys that would detect thin saturated zones in various parts of The Basin, would help to delineate both Quatemary and bedrock aquifers. The thickest or lowest parts of the Quaternary fill, which might be saturated, could thus be established. Additional study should include the drilling of several closely-spaced boreholes near the CCC wells so as to fully penetrate the Quaternary fill material and thus determine if a shallow bedrock aquifer exists. This would indicate the source of water for these shallow CCC wells and would verify the presence or absence of saturation in Quatemary fill material at these sites east of the sewage lagoons. The three dry test borings that were constructed as permanent hydrologic sites near the lagoons should be monitored periodically to determine if there is continued absence of saturation. The absence of saturation would indicate that no significant leakage from the lagoons is occurring at these sites.

A carefully designed borehole that penetrates the igneous intrusive rock at The Window would provide much needed information on whether or not water in The Basin is moving in the subsurface through the rock as fracture flow. This possible movement of water is presently a matter of speculation, and such knowledge could strengthen or modify conclusions regarding recharge to Oak Spring. Also drilling in the Oak Spring area of several more judiciously located boreholes would help delineate the Oak Spring aquifer more extensively. This is a complex area largely covered by a boulder field. Bedrock exposures are rare and widely distributed; consequently, drilling would yield useful information regarding the position and outcrop or subcrops (recharge area) of the aquifer.

A continuous record of flow of Oak Spring, coupled with precipitation records, would allow for establishment of the long-term precipitation-discharge relation. Periodic sampling of Oak Spring, for a comprehensive list of properties and constituents, would document the expected continuance of the present quality of the water or any departure trends. Bacterial sampling of Oak Spring discharge on a more frequent basis and spanning a range of observed discharge would be required to conclusively verify the temporal variability of bacteria in the spring flow. 


\section{REFERENCES CITED}

American Public Health Association, 1985, Standard methods for the examination of water and wastewater, 16th ed., jointly published by: American Public Health Association, American Water Works Association, and the Water Pollution Control Federation, Washington, D.C., p. 946-974.

Archer, J.A., 1982, A hydrogeological evaluation of alluvial fans in northern Big Bend National Park, Texas, using geophysical methods: College Station, Texas, Texas A\&M University, unpublished M.S. thesis, 105 p.

Back, William, 1966, Hydrochemical facies and groundwater flow patterns in northern part of Atlantic Coastal Plain: U.S. Geological Survey Professional Paper 498A, 42 p.

Baker, R.C., 1958, Water supply for Persimmon Gap and Santa Elena ranger stations, Big Bend National Park, Brewster County, Texas: U.S. Geological Survey Open-File Report, 23 p.

Barber, L.B., 1985, Geochemistry of organic and inorganic compounds in a sewage contaminated aquifer, Cape Cod, Massachusetts: Boulder, Colorado, University of Colorado, M.S. thesis, $169 \mathrm{p}$.

Barber, L.B., Thruman, E.M., Schroeder, M.P., and Leblanc, D.R., 1988, Long-term fate of organic micropollutants in sewage-contaminated ground water: Environmental Science and Technology, v. 22, no. 2, p. 205-211.

Busbey, A.B., Lambert, D.D., Ross, M.L., and Morgan, K.M., 1986, Geologic overview of Big Bend National Park using Landsat imagery, in Geology of the Big Bend area and Solitario dome, Texas: West Texas Geological Society, Publication 86-82, p. 75-82.

Faure, Gunther, 1977, Principles of isotope geology: New York, John Wiley and Sons, p. 45-47, 328-330.

Fishman, M.J., and Friedman, L.C., 1985, Methods for the determination of inorganic substances in water and fluvial sediments: U.S. Geological Survey Open-File Report 85-495, 709 p.

Freeze, R.A. and Cherry, J.A., 1979, Groundwater: New York, Prentice-Hall, Inc., 604 p.

Gormly, J.R., and Spaulding, R.J., 1979, Sources and concentrations of nitrate-nitrogen in ground water of the Central Platte region, Nebraska: Ground Water, v. 17, p. 291-301.

Gottfried, David, Moore, Roosevelt, and Caemmerer, Alice, 1962, Thorium and uranium in some alkalic igneous rocks from Virginia and Texas, in Geological Survey Research 1962: U.S. Geological Survey Professional Paper 450-B, p. B70-72.

Greeson, P.E., Ehlke, T.A., Irwin, G.A., Lium, B.W., and Slack, K.V., 1977, Methods for collection and analysis of aquatic biological and microbiological samples:
U.S. Geological Survey Techniques of Water-

Resources Investigations, Book 5, Ch. A4, p. 21-66.

Hammermeister, D.P., Blout, D.O., and McDaniel, J.C., 1985, Drilling and coring methods that minimize the disturbance of cuttings, core, and rock formation in the unsaturated zone, Yucca Mountain, Nevada, in Proceedings of the National Water Well Association Conference on Characterization of the vadose (unsaturated) zone: Denver, Colorado, National Water Well Association, November 19-21, 1985, p. 507-540.

Hem, J.D., 1985, Study and interpretation of the chemical characteristics of natural water: U.S. Geological Survey Water-Supply Paper 2254, 264 p.

Hoy, R.N., and Gross, G.W., 1982, A baseline study of oxygen-18 and deuterium in the Roswell, New Mexico, groundwater basin: New Mexico Institute of Mining and Technology, Partial Technical Completion Report, Project No. B-059-NMEX, 95 p.

International Atomic Energy Agency, 1983, Isotope techniques in the hydrogeological assessment of potential sites for the disposal of high-level radioactive wastes: Vienna, International Atomic Energy Agency, Technical Reports Series no. 228, 151 p.

Kreitler, C.W., 1975, Determining the source of nitrate-nitrogen in ground water by nitrogen isotope studies: Austin, University of Texas, Bureau of Economic Geology Report of Investigations 83, $57 \mathrm{p}$.

Leblanc, D.R., 1982, Sewage plume in a sand and gravel aquifer: U.S. Geological Survey Open-File Report 82274, 35 p.

Leggat, E.R., 1963, Water supply for the Castolon area, Big Bend National Park, Brewster County, Texas: U.S. Geological Survey Open-File Report, 19 p.

Lopez-Sepulveda, H.J., 1984, Environmental isotope and geochemical investigation of ground water in Big Bend National Park, Texas: College Station, Texas, Texas A\&M University, unpublished M.S. thesis, 107 p.

Maxwell, R.A., 1985, Big Bend country: Big Bend Natural History Association, Big Bend National Park, Texas, $88 \mathrm{p}$.

Maxwell, R.A., Lonsdale, J.T., Hazzard, R.T., and Wilson, J.A., 1967, Geology of Big Bend National Park, Brewster County, Texas: Austin, University of Texas, Bureau of Economic Geology Publication 6711, 320 p.

Monti, Joseph, 1984, Seismic mapping of alluvial fans and sub-fan bedrock in Big Bend National Park, Texas: College Station, Texas, Texas A\&M University, unpublished M.S. thesis, 52 p.

Parkhurst, D.L., Thorstenson, D.C., and Plummer, L.N., 1980, PHREEQE - A computer program for geochemical calculations: U.S. Geological Survey WaterResources Investigations Report 80-96, 216 p.

Rawson, Jack, 1963, Quality of water from test wells in the Castolon area, Big Bend National Park, Brewster 
County, Texas: U.S. Geological Survey Open-File Report, 12 p.

Scott, J.H., 1977, SIPT - A seismic-refraction inverse modeling program for time-share terminal computer systems: U.S. Geological Survey Open-File Report 77$365,34 \mathrm{p}$.

Scott, J.H., Tibbetts, B.L., and Burdick, R.G., 1972, Computer analysis of seismic refraction data: U.S. Bureau of Mines Report of Investigations 7595, 95 p.

Slaine, D.D., and Barker, J.F., 1990, The detection of naturally occurring BTX during a hydrogeologic investigation: Ground Water Monitoring Review, v. 10, no. 2, p. 89-94.

Texas Register, 1977, Drinking-water standards governing drinking-water quality and reporting requirements for public-water-supply systems: v. 2, Regulation no. 337.17, June 14, 1977.

U.S. Environmental Protection Agency, 1985, National primary drinking water regulations: Federal Register, v. 50, no. 219 , pt. III, p. $46,880-46,932$. 1986a, Maximum contaminant levels (subpart B of part 141, national primary drinking-water regulations): U.S. Code of Federal Regulations, Title 40, parts 100 to 149 , revised as of July 1, 1986, p. 521-528.

$1986 \mathrm{~b}$, Secondary maximum contaminant levels (section 143.3 of part 143, national secondary drinkingwater regulations): U.S. Code of Federal Regulations, Title 40, parts 100 to 149 , revised as of July 1,1986 , p. 587-590.

1990, Drinking-water regulations under the Safe Drinking Water Act, May 1990: Washington, D.C., Fact sheet, Office of Drinking Water, $43 \mathrm{p}$.

Wershaw, R.L., Fishman, M.J., Grabbe, R.R., and Lowe, L.E., 1983, Methods for the determination of organic substances in water and fluvial sediments: U.S. Geological Survey Techniques of Water-Resources Investigations, Book 5, Ch. A3, 180 p.

Wood, W.W., 1976, Guidelines for collection and field analysis of ground-water samples for selected unstable constituents: U.S. Geological Survey Techniques of WaterResources Investigations, Book 1, Ch. D2, 24 p. 
Table 1. Descriptions of borehole cores, Oak Spring area

Test boring : : TB-5

Owner : : Big Bend National Park

Driller : U.S. Geological Survey (USGS)

Described by : : Ted A. Small, Geologist, USGS, San Antonio, Texas

\section{Description}

Thlckness

(feet)

10

10

Rhyolite, riebeckite, light gray, joints (or fractures?) common to abundant, most joints closed, some open, most at high angle $\left(60^{\circ}\right)$ some joints (at a lower angle) are approximately at right angles to the high-angle joints

Clay, maroon-red brown-dark gray in center, waxy to earthy, platy, compact

Sandstone, light tan, fine- to medium-grained, sub-angular to sub-round, well indurated, calcareous cement

Clay, maroon, waxy, platy, compact, calcareous

Gap--core missing ${ }^{1}$

Sandstone, quartz, loose, argillaceous (?)

Clay, maroon, compact, waxy, brittle (crumbly), platy, arenaceous 67.5-68 feet with individual grains of quartz sand

Gap-core missing ${ }^{1}$

Sandstone, red-brown, loose to very friable, round to subround, slightly argillaceous

Gap-core missing ${ }^{l}$

Clay, mottled maroon-gray-green, waxy-earthy, platy, variably calcareous

Clay, dark gray, brittle, waxy, platy, with inclusions of nodular gypsum and 1/16- to 1/8-inch gypsum seams at 103.4 and 104.5 feet

5

Clay, mottled maroon-gray-yellow, compact to brittle, variably crumbly, 1/16-inch gypsum seams at $105.3,105.65,106.15$, and 107.7 feet

\footnotetext{
Test boring : TB-6

Owner : Big Bend National Park

Driller : USGS

Described by : Ted A. Small, Geologist, USGS, San Antonio, Texas
}

\section{Description}


Tabie 1. Descriptions of borehole cores, Oak Spring area--Continued

Test boring : TB-6-Continued

\section{Description}

Thickness

Depth

(foet)

(feet)

Rhyolite, riebeckite, gray, hard, high-angle joints (or fractures?) common to abundant, some

filled with calcite, some open (boulder zone--many small boulders)

42

Rhyolite, riebeckite, gray, high-angle joints abundant, low-angle joints rare to common, most joints closed, some are open (by coring action?) (single large boulder?)

Rhyolite, riebeckite, gray, high-angle joints common to abundant, low-angle joints rare to common, most joints are closed (single boulder?)

Rhyolite, riebeckite, gray to brown, joints abundant, some open and lined with thin veneer of dark brown calcareous material. Small, dark, unidentified crystals on joint faces rare to common

Test boring : TB-7

Owner : Big Bend National Park

Driller : USGS

Described by : Ted A. Small, Geologist, USGS, San Antonio, Texas

\section{Description}

\section{Thickness \\ (feet)}

10

10

Rockbit cuttings--rhyolite and surface soil

Rhyolite, riebeckite, gray, hard, joints (or fractures) common to abundant, mostly high angle (major system--high angle, secondary system--low angle and at right angles to major system), most joints open

Rhyolite, riebeckite, gray, hard jointed, high-angle joints common to abundant, low-angle joints rare to common, many joints open (by coring action?), some brown clay coating core and between pieces of core. Clay is dark brown to red-brown to maroon, hard to soft, variably calcareous

Gap--core missing ${ }^{1}$

Clay, maroon, waxy, compact, platy, variably calcareous

Clay, maroon to gray, waxy, compact, platy, sticky, with a few individual grains of medium- to coarse-grained quartz sand

Gap--core missing ${ }^{1}$

Footnote at end of table. 
Table 1. Descriptions of borehole cores, Oak Spring area--Continued Test boring : TB-7--Continued

\section{Description}

Clay, gray with maroon tint, earthy, compact, platy, calcareous

Gap--core missing ${ }^{1}$

Clay, gray, earthy to waxy, compact, platy, with small inclusions (nodules) of very hard clay

Sandstone, light gray, tan, quartz, cross-bedded, fine- to medium-grained, sub-rounded, poorly sorted, well indurated, argillaceous

Clay, gray, earthy to waxy, compact, platy, calcareous

Sandstone, light gray, fine-grained, sub-round, well sorted, moderately well indurated, slightly calcareous

Clay, mottled maroon to gray with some yellow and green, waxy, compact to brittle, platy, with hard nodular inclusions of clay, variably calcareous limestone up to 1-inch diameter common

Sandstone, light gray, fine-grained, well indurated, calcareous, with thin maroon and yellow clay laminations

Total depth

4

109

5

Clay, mottled maroon to gray, waxy to earthy, compact, platy, nodular limestone inclusions rare, variably calcareous

\footnotetext{
${ }^{1}$ Core missing because of core-barrel blockage, water action, or looseness of formation material.
} 
Table 4. Water-quality data for selected locations, The Basin and Oak Spring areas and Cattail Falls, 1954-89

[ft ${ }^{3} / \mathrm{s}$, cubic feet per second; $\mu \mathrm{S} / \mathrm{cm}$, microsiemens per centimeter at $25^{\circ} \mathrm{C} ; \mathrm{mg} / \mathrm{L}$, milligrams per liter, $\mathrm{CaCO}_{3}$, calcite; wat wh, tot fet, water whole, total fixed-end point titration; --, not determined; <, less than; $\mathrm{N}$, nitrogen; ${ }^{\circ} \mathrm{C}$, degrees Celsius; $\mathrm{mm} \mathrm{Hg}$, height of an equivalent column of mercury in millimeters; P, phosphorus; $\mathrm{C}$, carbon; $\mu \mathrm{g} / \mathrm{L}$, micrograms per liter; $\mathrm{PCi} / \mathrm{L}$, picocuries per liter, U-nat, natural nranium; Cs-137, cesium-137; Sr/Yt-90, strontium/yttrium-90; TU, tritium units; -, negative value]

\begin{tabular}{|c|c|c|c|c|c|c|c|c|c|}
\hline $\begin{array}{l}\text { Local } \\
\text { Identlfier }\end{array}$ & Date & Tlme & $\begin{array}{l}\text { Spring } \\
\text { flow or } \\
\text { dlecharge, } \\
\text { Instan- } \\
\text { taneous } \\
\left(\mathrm{ft}^{3} / \mathrm{s}\right)\end{array}$ & $\begin{array}{c}\text { Specific } \\
\text { conduct- } \\
\text { ance } \\
(\mu \mathrm{S} / \mathrm{cm})\end{array}$ & $\begin{array}{c}\text { pH } \\
\text { (otandard } \\
\text { unlts) }\end{array}$ & $\begin{array}{c}\text { Hard- } \\
\text { ness, } \\
\text { total } \\
\left(\mathrm{mg}^{2} \mathrm{as}\right. \\
\left.\mathrm{CaCO}_{3}\right)\end{array}$ & $\begin{array}{l}\text { Alkallnity, } \\
\text { wat wh, } \\
\text { tot fot, } \\
\text { field } \\
(\mathrm{mg} / \mathrm{L} \text { as } \\
\left.\mathrm{CaCO}_{3}\right)\end{array}$ & $\begin{array}{l}\text { Sollds, } \\
\text { sum of } \\
\text { con- } \\
\text { stituents, } \\
\text { dlssolved } \\
\text { (mg/L) }\end{array}$ & $\begin{array}{l}\text { Calclum, } \\
\text { dis- } \\
\text { solved } \\
\text { (mg/h) }\end{array}$ \\
\hline BK-73-46-701 & $03-09-54$ & 1200 & 0.04 & 322 & 7.5 & 100 & 114 & 210 & 38 \\
\hline \multirow{7}{*}{ (Oak Spring) } & $07-13-60$ & 1200 & -- & 301 & 7.2 & 100 & 110 & 210 & 37 \\
\hline & $06-25-64$ & 1200 & .07 & 305 & 7.0 & 110 & 112 & 200 & 40 \\
\hline & $03-12-65$ & 1200 & .02 & 320 & 8.1 & 110 & 110 & 200 & 40 \\
\hline & $04-19-69$ & 1200 & -- & 336 & 7.3 & 110 & 116 & -- & 42 \\
\hline & $08-24-87$ & 1400 & .3 & 353 & 7.5 & 130 & 126 & 240 & 47 \\
\hline & $03-11-88$ & 1500 & .04 & 368 & 7.6 & -- & .. & -- & -. \\
\hline & $09-19-89$ & 1200 & -- & 365 & 6.8 & 130 & 121 & 230 & 47 \\
\hline BK-73-46-702 & $03-09-54$ & 1200 & -- & 569 & 8.0 & 190 & 150 & 410 & 70 \\
\hline \multirow[t]{5}{*}{ (Cattail Falls) } & $07-17-66$ & 1200 & .11 & 115 & 6.7 & 35 & 18 & -- & -- \\
\hline & $06-25-86$ & 1630 & 5.0 & 91 & 6.5 & 31 & 8 & 76 & 11 \\
\hline & $09-15-87$ & 1200 & $<.01$ & 196 & 8.1 & 63 & 38 & 140 & 23 \\
\hline & $03-11-88$ & 1100 & -- & 436 & 7.4 & -- & -- & -- & -- \\
\hline & $09-19-89$ & 0930 & $<.01$ & 814 & 7.6 & 35 & 246 & 510 & 13 \\
\hline $\begin{array}{l}\text { Conservation } \\
\text { Corps well) }\end{array}$ & $03-10-88$ & 0930 & -- & 225 & 7.3 & -- & -- & -- & -- \\
\hline BK-73-46-804 & $05-10-72$ & 0900 & .07 & 482 & 7.6 & 150 & 190 & 320 & 57 \\
\hline (Window & $06-25-86$ & 1510 & .02 & 295 & 6.3 & 170 & 162 & 280 & 64 \\
\hline \multirow[t]{2}{*}{ Spring) } & $08-25-87$ & 1438 & .05 & -- & 6.8 & 150 & 130 & 270 & 55 \\
\hline & $03-13-88$ & 1400 & .05 & 444 & 8.3 & -- & - & -- & -- \\
\hline National Park & $06-24-86$ & 1630 & -- & 611 & 9.6 & 65 & 93 & 360 & 23 \\
\hline $\begin{array}{l}\text { Service, Big } \\
\text { Bend lower } \\
\text { sewage lagoon }\end{array}$ & $08-26-87$ & 1430 & -- & 498 & 9.5 & 96 & 107 & 330 & 36 \\
\hline
\end{tabular}


Table 4. Water-quality data for selected locations, The Basin and Oak Spring areas and Cattail Falls, 1954-89-Continued

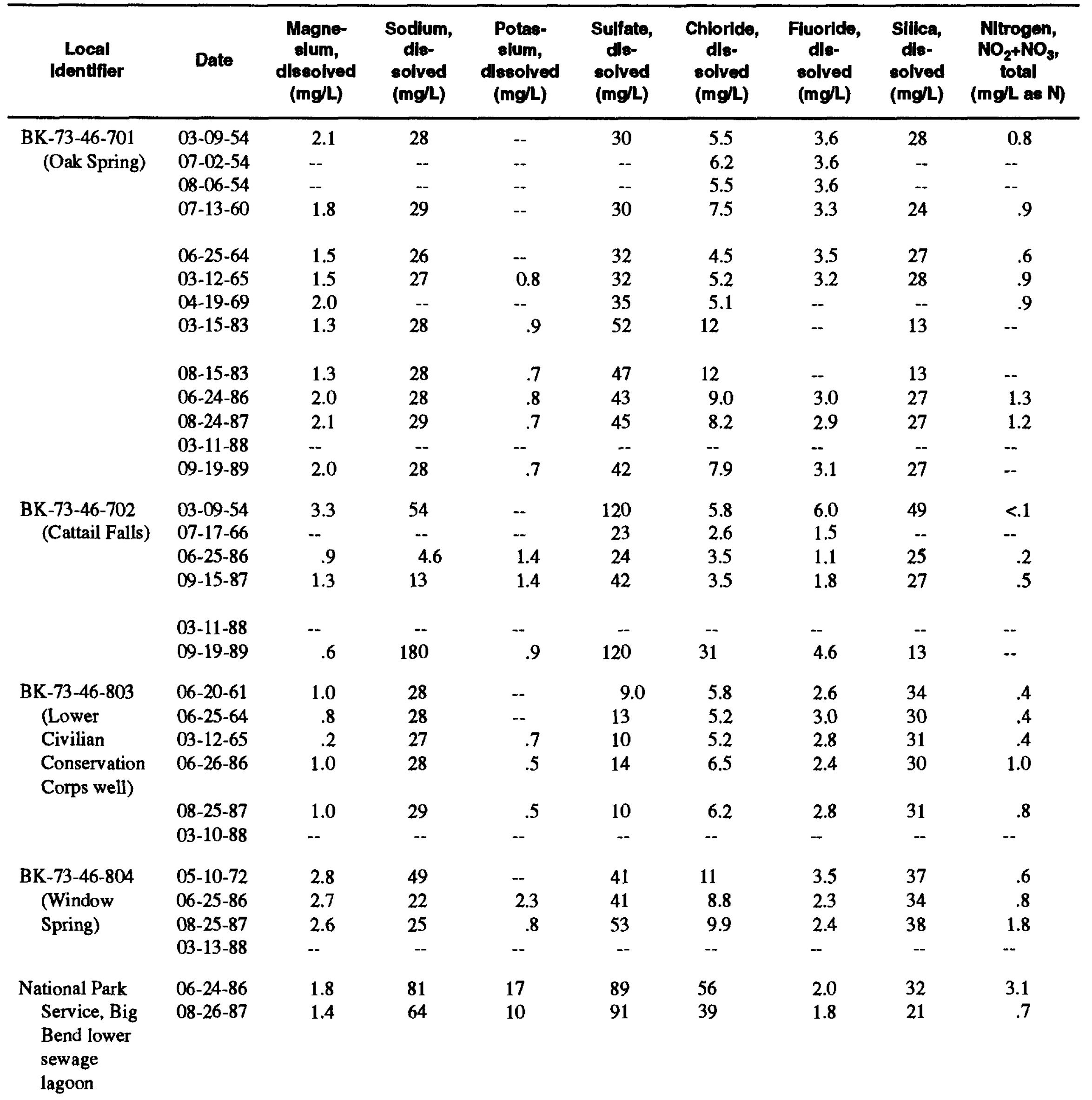


Table 4. Water-quality data for selected locations, The Basin and Oak Spring areas and Cattail Falls, 1954-89-Continued

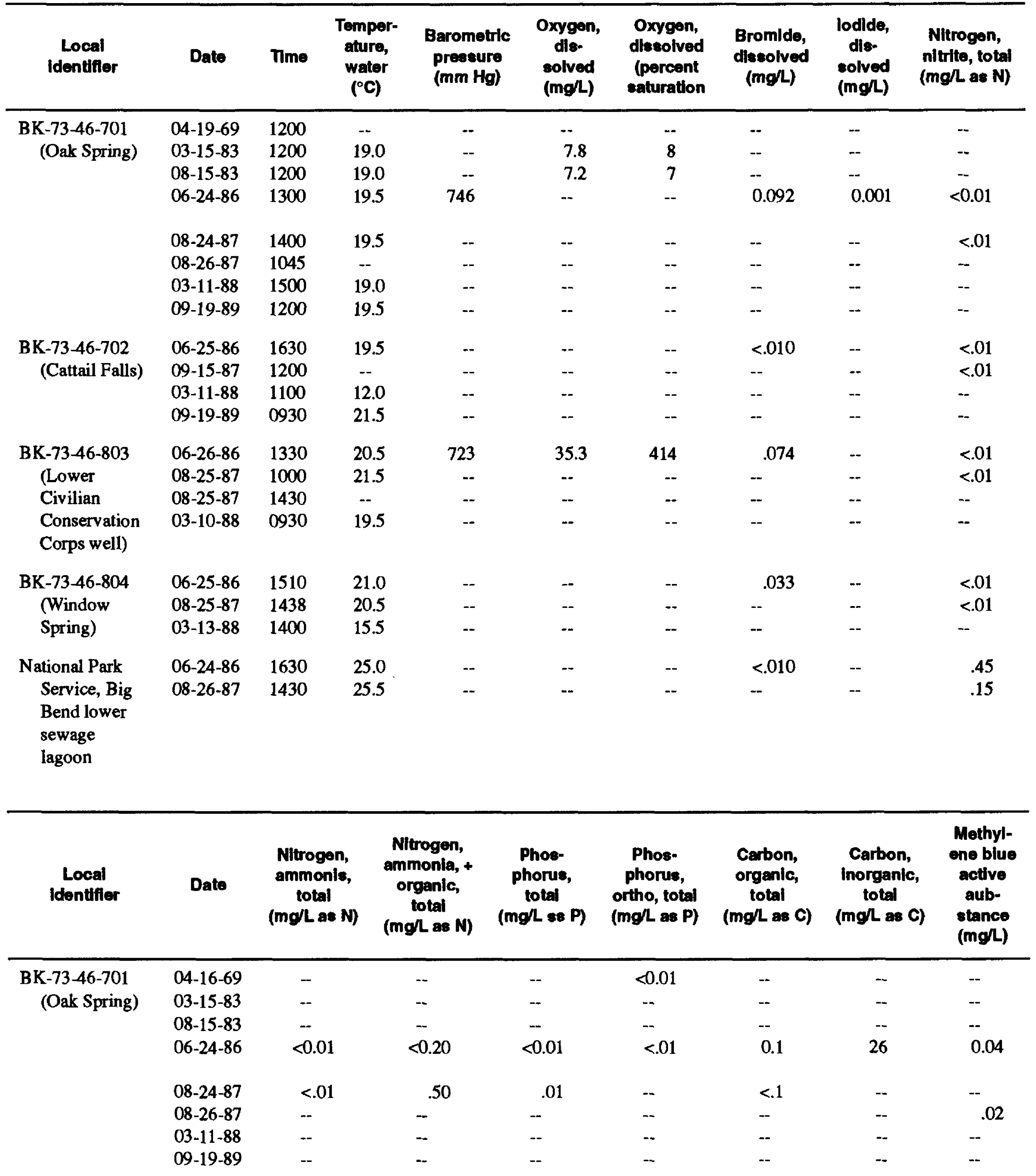


Table 4. Water-quality data for selected locations, The Basin and Oak Spring areas and Cattail Falls, 1954-89-Continued

\begin{tabular}{|c|c|c|c|c|c|c|c|c|c|}
\hline $\begin{array}{l}\text { Local } \\
\text { Identifier }\end{array}$ & Date & $\begin{array}{c}\text { Nitrogen, } \\
\text { ammonla, } \\
\text { total } \\
\text { (mgl as N) }\end{array}$ & $\begin{array}{r}\text { Nitr } \\
\text { amm } \\
\text { org } \\
\text { to } \\
\text { (mgll }\end{array}$ & $\begin{array}{l}\text { jen, } \\
\text { la, + } \\
\text { olc, } \\
\text { ai } \\
\text { as N) }\end{array}$ & $\begin{array}{l}\text { Phos" } \\
\text { phorus, } \\
\text { total } \\
\text { ngll as P) }\end{array}$ & $\begin{array}{l}\text { Phos" } \\
\text { phorus, } \\
\text { ortho, total } \\
\text { mgles P) }\end{array}$ & $\begin{array}{c}\text { Carbon, } \\
\text { organic, } \\
\text { total } \\
\text { (mg/l as C) }\end{array}$ & $\begin{array}{c}\text { Carbon, } \\
\text { Inorganlc, } \\
\text { total } \\
\text { (mgll as C) }\end{array}$ & $\begin{array}{l}\text { Mothyl- } \\
\text { ene bluo } \\
\text { active } \\
\text { sub- } \\
\text { stance } \\
\text { (mgll) }\end{array}$ \\
\hline $\begin{array}{l}\text { BK-73-46-702 } \\
\text { (Cattail Falls) }\end{array}$ & $\begin{array}{l}06-25-86 \\
09-15-87 \\
03-11-88 \\
09-19-89\end{array}$ & $\begin{array}{l}0.02 \\
<.01 \\
-- \\
--\end{array}$ & $\begin{array}{l}\mathrm{C} \\
- \\
-\end{array}$ & & $\begin{array}{r}0.01 \\
.01 \\
-- \\
--\end{array}$ & $\begin{array}{l}<0.01 \\
-- \\
-- \\
-\end{array}$ & $\begin{array}{l}-- \\
-- \\
--\end{array}$ & $\begin{array}{l}-- \\
-- \\
--\end{array}$ & 0.02 \\
\hline $\begin{array}{l}\text { BK-73-46-803 } \\
\text { (Lower } \\
\text { Civilian } \\
\text { Conservation } \\
\text { Corps well) }\end{array}$ & $\begin{array}{l}06-26-86 \\
08-25-87 \\
08-25-87 \\
03-10-88\end{array}$ & $\begin{array}{r}.02 \\
<.01 \\
-- \\
--\end{array}$ & - & $\begin{array}{l}30 \\
50\end{array}$ & $\begin{array}{r}.02 \\
.02 \\
-- \\
--\end{array}$ & $\begin{array}{l}.01 \\
-- \\
-- \\
--\end{array}$ & $\begin{array}{l}-- \\
<0.1 \\
--\end{array}$ & $\begin{array}{l}-- \\
-- \\
--\end{array}$ & $\begin{array}{r}.04 \\
.02 \\
.03 \\
-\end{array}$ \\
\hline $\begin{array}{l}\text { National Park } \\
\text { Service, Big } \\
\text { Bend lower } \\
\text { sewage } \\
\text { lagoon }\end{array}$ & $\begin{array}{l}06-24-86 \\
08-26-87\end{array}$ & $\begin{array}{l}.16 \\
.57\end{array}$ & & & $\begin{array}{r}.86 \\
1.90\end{array}$ & .34 & $\begin{array}{l}28 \\
27\end{array}$ & $\begin{array}{r}14 \\
--\end{array}$ & $\begin{array}{l}.11 \\
.14\end{array}$ \\
\hline $\begin{array}{l}\text { Local } \\
\text { Identifier }\end{array}$ & Date & dit & $\begin{array}{l}\text { Areenle, } \\
\text { lesolved } \\
(\mu g / L)\end{array}$ & $\begin{array}{l}\text { Barium, } \\
\text { dlesolved } \\
\text { ( } \mu g / L)\end{array}$ & $\begin{array}{l}\text { Boron, } \\
\text { dlseolved } \\
(\mu g / L)\end{array}$ & $\begin{array}{c}\text { Cadmium, } \\
\text { diesolved } \\
(\mu g / \mathrm{L})\end{array}$ & $\begin{array}{c}\text { Chromlum, } \\
\text { diseolved } \\
(\mu g / L)\end{array}$ & $\begin{array}{l}\text { Copper, } \\
\text { dls- } \\
\text { solved } \\
(\mu g / L)\end{array}$ & $\begin{array}{l}\text { Iron, } \\
\text { dlis- } \\
\text { solved } \\
(\mu g / L)\end{array}$ \\
\hline $\begin{array}{l}\text { BK-73-46-702 } \\
\text { (Cattail Falls) }\end{array}$ & $06-25-86$ & 1630 & -- & -- & 20 & - & -- & $\ldots$ & - \\
\hline $\begin{array}{l}\text { BK-73-46-803 } \\
\text { (Lower } \\
\text { Civilian } \\
\text { Conservation } \\
\text { Corps well) }\end{array}$ & $\begin{array}{l}06-26-86 \\
08-25-87\end{array}$ & $\begin{array}{l}1330 \\
1000\end{array}$ & $\begin{array}{c}2 \\
--\end{array}$ & $\begin{array}{r}34 \\
--\end{array}$ & $\begin{array}{l}120 \\
120\end{array}$ & $\begin{array}{l}1.0 \\
--\end{array}$ & $\begin{array}{r}<10 \\
--\end{array}$ & $\begin{array}{r}4 \\
--\end{array}$ & $\begin{array}{l}13 \\
<3\end{array}$ \\
\hline $\begin{array}{c}\text { BK-73-46-804 } \\
\text { (Window } \\
\text { Spring) }\end{array}$ & $\begin{array}{l}06-25-86 \\
08-25-87\end{array}$ & $\begin{array}{l}1510 \\
1438\end{array}$ & $\begin{array}{l}<1 \\
--\end{array}$ & $\begin{array}{r}49 \\
--\end{array}$ & $\begin{array}{l}70 \\
80\end{array}$ & $\begin{array}{l}1.0 \\
-\end{array}$ & $\begin{array}{r}<10 \\
--\end{array}$ & $\begin{array}{l}4 \\
--\end{array}$ & $\begin{array}{r}8 \\
<3\end{array}$ \\
\hline $\begin{array}{l}\text { National Park } \\
\text { Service, Big } \\
\text { Bend lower } \\
\text { sewage lagoon }\end{array}$ & $\begin{array}{l}06-24-86 \\
08-26-87\end{array}$ & $\begin{array}{l}1630 \\
1430\end{array}$ & -- & -- & $\begin{array}{l}550 \\
270\end{array}$ & - & - & -- & -- \\
\hline
\end{tabular}


Table 4. Water-quality data for selected locations, The Basin and Oak Spring areas and Cattail Falls, 1954-89-Continued

\begin{tabular}{|c|c|c|c|c|c|c|c|c|c|c|c|}
\hline $\begin{array}{l}\text { Local } \\
\text { Identifier }\end{array}$ & \multicolumn{2}{|c|}{ Date } & $\begin{array}{l}\text { Lead, } \\
\text { dlesolved } \\
\text { ( } \mu g(L)\end{array}$ & \multicolumn{2}{|c|}{$\begin{array}{l}\text { Mangansse, } \\
\text { dissolved } \\
(\mu g / L)\end{array}$} & $\begin{array}{l}\text { Morcury, } \\
\text { dlssolved } \\
(\mu g h)\end{array}$ & $\begin{array}{l}\text { Selenium, } \\
\text { dlesolved } \\
(\mu g / L)\end{array}$ & $\begin{array}{l}\text { Silver, } \\
\text { dlseolved } \\
(\mu g / L)\end{array}$ & \multicolumn{2}{|c|}{$\begin{array}{l}\text { Strontlum, } \\
\text { diesolved } \\
(\mu \mathrm{g} / \mathrm{L})\end{array}$} & $\begin{array}{l}\text { Zlnc, } \\
\text { diseolved } \\
(\mu g / L)\end{array}$ \\
\hline $\begin{array}{l}\text { BK-73-46-701 } \\
\text { (Oak Spring) }\end{array}$ & $\begin{array}{l}03-15-8 \\
08-15-8 \\
06-24-8 \\
08-24-8\end{array}$ & & $\begin{array}{l}- \\
-- \\
<5 \\
--\end{array}$ & $\begin{array}{l}-- \\
-- \\
<1 \\
<1\end{array}$ & & $\begin{array}{l}-- \\
- \\
0.1 \\
--\end{array}$ & $\begin{array}{l}-- \\
- \\
2 \\
--\end{array}$ & $\begin{array}{l}-- \\
- \\
\cdot<1.0 \\
--\end{array}$ & 350 & & $\begin{array}{c}-- \\
-- \\
40 \\
--\end{array}$ \\
\hline $\begin{array}{l}\text { BK-73-46-702 } \\
\quad \text { (Cattail Falls) }\end{array}$ & $06-25-8$ & & -- & - & & -- & - & -- & - & &.- \\
\hline $\begin{array}{l}\text { BK-73-46-803 } \\
\text { (Lower Civilian } \\
\text { Conservation } \\
\text { Corps well) }\end{array}$ & $\begin{array}{l}06-26-8 \\
08-25-8\end{array}$ & & $<5$ & $\begin{array}{l}2 \\
9\end{array}$ & & $\begin{array}{l}<.1 \\
--\end{array}$ & $\begin{array}{l}1 \\
--\end{array}$ & $\begin{array}{l}<1.0 \\
--\end{array}$ & 110 & & $\begin{array}{r}17 \\
--\end{array}$ \\
\hline $\begin{array}{l}\text { BK-73-46-804 } \\
\text { (Window } \\
\text { Spring) }\end{array}$ & $\begin{array}{l}06-25-8 \\
08-25-8\end{array}$ & & $\begin{array}{l}<5 \\
--\end{array}$ & $\begin{array}{r}2 \\
<1\end{array}$ & & $\begin{array}{l}<.1 \\
--\end{array}$ & $\begin{array}{l}1 \\
--\end{array}$ & $\begin{array}{l}<1.0 \\
--\end{array}$ & 490 & & $\begin{array}{l}15 \\
-.\end{array}$ \\
\hline $\begin{array}{l}\text { National Park } \\
\text { Service, Big } \\
\text { Bend lower } \\
\text { sewage lagoon }\end{array}$ & $\begin{array}{l}06-24-8 \\
08-26-8\end{array}$ & & - & $\overline{2}$ & & $\begin{array}{l}-. \\
--\end{array}$ & $\begin{array}{l}- \\
--\end{array}$ & $\begin{array}{l}-- \\
--\end{array}$ & 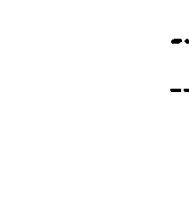 & & $\begin{array}{l}-- \\
-\end{array}$ \\
\hline $\begin{array}{l}\text { Local } \\
\text { Identifier }\end{array}$ & Date & $\pi m e$ & $\begin{array}{l}\text { Grose } \\
\text { alpha, } \\
\text { dls- } \\
\text { solved } \\
\text { (pCVL } \\
\text { U-nat) }\end{array}$ & $\begin{array}{c}\text { Gross } \\
\text { alpha, } \\
\text { susp., } \\
\text { totad } \\
\text { (ug/L as } \\
\text { U-nat) }\end{array}$ & & $\begin{array}{l}\text { Gross } \\
\text { beta, } \\
\text { dls- } \\
\text { solved } \\
\text { pCVL as } \\
\text { Cs-137) }\end{array}$ & $\begin{array}{l}\text { Gross } \\
\text { beta, } \\
\text { susp., } \\
\text { total } \\
\text { (pcVL as } \\
\text { Cs-137) }\end{array}$ & $\begin{array}{l}\text { Gross } \\
\text { beta, } \\
\text { dis- } \\
\text { solved } \\
\text { (pCl/L } \\
\text { Sr/Yt-90) }\end{array}$ & $\begin{array}{l}\text { Groes } \\
\text { beta, } \\
\text { susp., } \\
\text { total } \\
\text { (pCln as } \\
\text { SrNi-go) }\end{array}$ & $\begin{array}{l}\text { Radlum } \\
226, \\
\text { dls- } \\
\text { soived, } \\
\text { radon } \\
\text { method } \\
\text { (pCVL) }\end{array}$ & 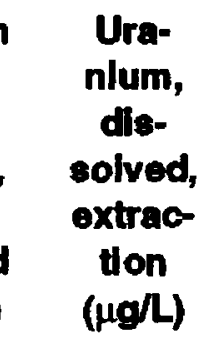 \\
\hline $\begin{array}{l}\text { BK-73-46-701 } \\
\text { (Oak } \\
\text { Spring) }\end{array}$ & $06-24-86$ & 1300 & 14.3 & $<1.0$ & & 4.2 & 1.4 & 3.5 & 1.4 & 0.06 & 9.9 \\
\hline $\begin{array}{l}\text { Local } \\
\text { Identifier }\end{array}$ & Date & Tme & $\begin{array}{l}\text { Ben- } \\
\text { zene, } \\
\text { total } \\
(\mu g / L)\end{array}$ & $\begin{array}{l}\text { Brome } \\
\text { form, } \\
\text { total } \\
(\mu g / L)\end{array}$ & $\begin{array}{l}\text { Car- } \\
\text { bon } \\
\text { tetra- } \\
\text { chlo- } \\
\text { rido, } \\
\text { total } \\
(\mu g / L)\end{array}$ & $\begin{array}{c}\text { Chloro- } \\
\text { ben- } \\
\text { zene, } \\
\text { total } \\
(\mu \mathrm{g} / \mathrm{L})\end{array}$ & $\begin{array}{l}\text { Chiorc- } \\
\text { dl- } \\
\text { broma- } \\
\text { meth- } \\
\text { ane, } \\
\text { lotal } \\
(\mu g / L)\end{array}$ & $\begin{array}{c}\text { Chloro- } \\
\text { ethane, } \\
\text { total } \\
\left(\mu g^{\prime} / \mathrm{L}\right)\end{array}$ & $\begin{array}{l}2- \\
\text { Chlore- } \\
\text { othyl } \\
\text { vinyl } \\
\text { other, } \\
\text { total } \\
\text { ( } \mu g / L)\end{array}$ & $\begin{array}{l}\text { Chloro- } \\
\text { form, } \\
\text { total } \\
(\mu g / L)\end{array}$ & $\begin{array}{c}\text { Cls-1,3- } \\
\text { Dl- } \\
\text { chloro- } \\
\text { pro- } \\
\text { pene, } \\
\text { total } \\
\text { ( } \mu g / L)\end{array}$ \\
\hline $\begin{array}{l}\text { BK-73-46-701 } \\
\quad \text { (Oak Spring) }\end{array}$ & $08-24-87$ & 1400 & $<0.2$ & $<0.2$ & $<0.2$ & $<0.2$ & $<0.2$ & $<0.2$ & $<0.2$ & $<0.2$ & $<0.2$ \\
\hline $\begin{array}{l}\text { BK-73-46-803 } \\
\text { (Lower } \\
\text { Civilian } \\
\text { Conservation } \\
\text { Corps well) }\end{array}$ & $08-25-87$ & 1000 & $<.2$ & $<.2$ & $<.2$ & $<.2$ & $<.2$ & $<.2$ & $<.2$ & $<.2$ & $<.2$ \\
\hline
\end{tabular}


Table 4. Water-quality data for selected locations, The Basin and Oak Spring areas and Cattail Falls, 1954-89-Continued

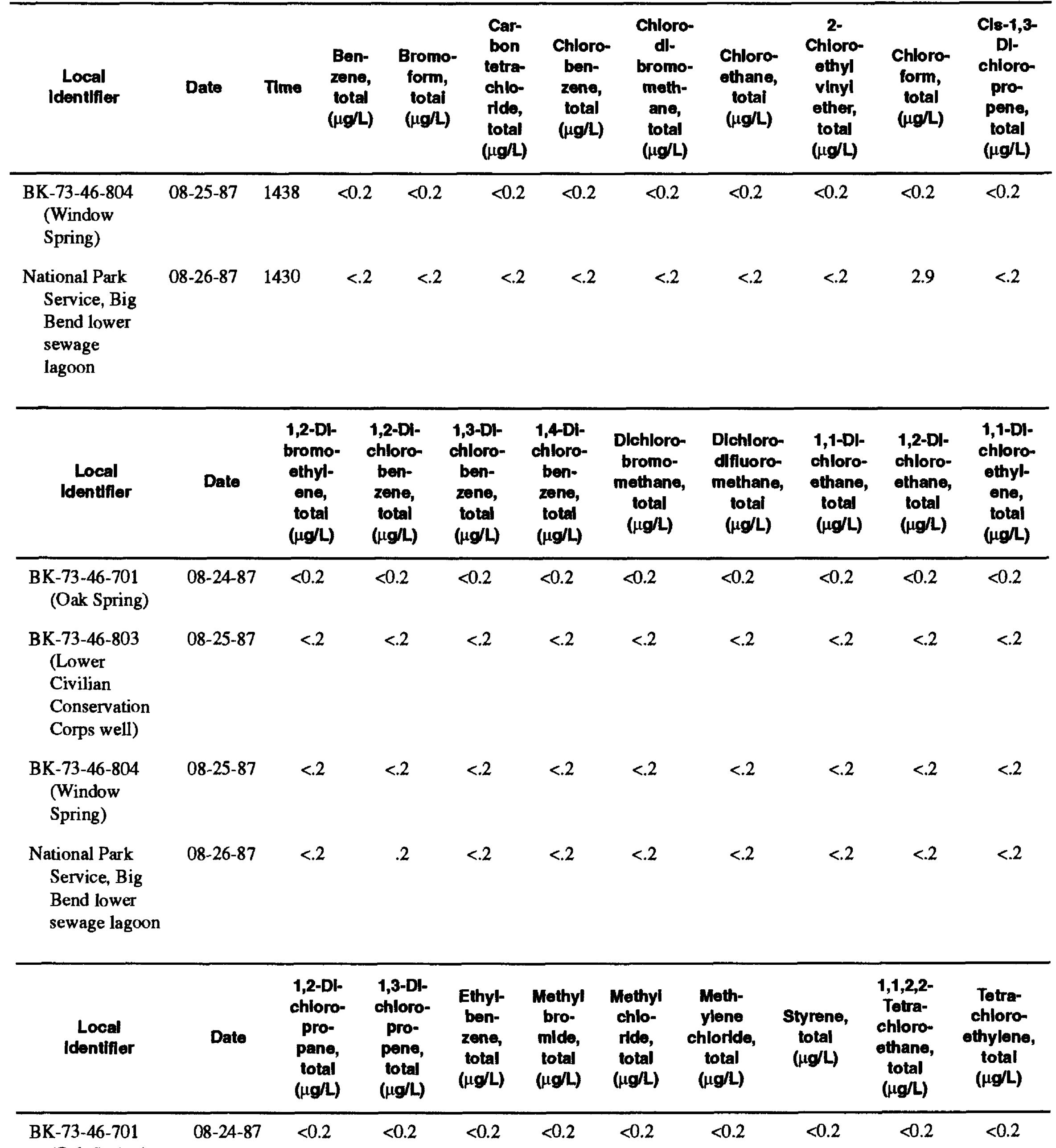

(Oak Spring) 
Tabie 4. Water-quality data for selected locations, The Basin and Oak Spring areas and Cattail Falls, 1954-89-Continued

\begin{tabular}{|c|c|c|c|c|c|c|c|c|c|c|}
\hline $\begin{array}{l}\text { Local } \\
\text { Identifier }\end{array}$ & Date & $\begin{array}{c}\text { 1,2-Di- } \\
\text { chloro- } \\
\text { pro- } \\
\text { pane, } \\
\text { total } \\
(\mu g /)\end{array}$ & $\begin{array}{c}\text { 1,3-Di- } \\
\text { chloro- } \\
\text { pro- } \\
\text { pene, } \\
\text { total } \\
(\mu g / L)\end{array}$ & $\begin{array}{l}\text { Ethyl- } \\
\text { ben- } \\
\text { zene, } \\
\text { total } \\
(\mu g / L)\end{array}$ & $\begin{array}{l}\text { Methyl } \\
\text { bro- } \\
\text { mide, } \\
\text { total } \\
(\mu g / \text { L) }\end{array}$ & $\begin{array}{l}\text { Mothyl } \\
\text { chio- } \\
\text { ride, } \\
\text { total } \\
(\mu g / L)\end{array}$ & $\begin{array}{l}\text { Meth- } \\
\text { ylene } \\
\text { chlorlde, } \\
\text { total } \\
(\mu g / L)\end{array}$ & $\begin{array}{c}\text { Styrene, } \\
\text { total } \\
(\mu g / \text { l) }\end{array}$ & $\begin{array}{c}\text { 1,1,2,2- } \\
\text { Tetre- } \\
\text { chloro- } \\
\text { othane, } \\
\text { total } \\
(\mu g / L)\end{array}$ & $\begin{array}{l}\text { Totra- } \\
\text { chloro- } \\
\text { ethylene, } \\
\text { total } \\
(\mu g / L)\end{array}$ \\
\hline $\begin{array}{l}\text { BK-73-46-803 } \\
\text { (Lower } \\
\text { Civilian } \\
\text { Conservation } \\
\text { Corps well) }\end{array}$ & $08-25-87$ & $<0.2$ & $<0.2$ & $<0.2$ & $<0.2$ & $<0.2$ & $<0.2$ & $<0.2$ & $<0.2$ & $<0.2$ \\
\hline $\begin{array}{c}\text { BK-73-46-804 } \\
\text { (Window } \\
\text { Spring) }\end{array}$ & $08-25-87$ & $<.2$ & $<.2$ & $<.2$ & $<.2$ & $<.2$ & $<.2$ & $<.2$ & $<.2$ & $<.2$ \\
\hline $\begin{array}{l}\text { Local } \\
\text { identifier }\end{array}$ & Date & $\begin{array}{l}\text { Tolu- } \\
\text { ene, } \\
\text { total } \\
(\mu g / L)\end{array}$ & $\begin{array}{c}\text { 1,2- } \\
\text { Trans- } \\
\text { dichloro- } \\
\text { ethene, } \\
\text { total } \\
(\mu \mathrm{g} / \mathrm{l})\end{array}$ & 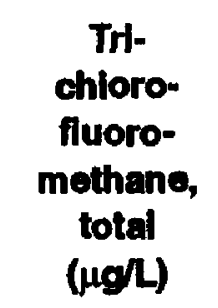 & 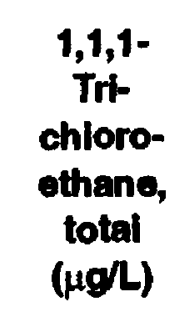 & $\begin{array}{c}1,1,2- \\
\text { Trt- } \\
\text { chloro- } \\
\text { ethane, } \\
\text { totel } \\
(\mu \mathrm{g} / \mathrm{L})\end{array}$ & $\begin{array}{l}\text { Tri- } \\
\text { chloro- } \\
\text { othylene, } \\
\text { total } \\
(\mu g / L)\end{array}$ & 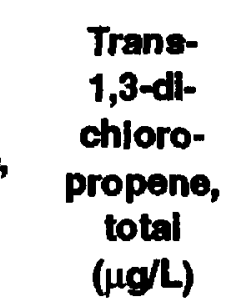 & $\begin{array}{l}\text { Vinyi } \\
\text { chlo- } \\
\text { ride, } \\
\text { total } \\
(\mu g / L)\end{array}$ & 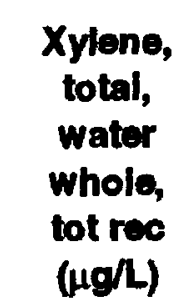 \\
\hline $\begin{array}{l}\text { BK-73-46-701 } \\
\text { (Oak Spring) }\end{array}$ & $08-24-87$ & $<0.2$ & $<0.2$ & $<0.2$ & $<0.2$ & $<0.2$ & $<0.2$ & $<0.2$ & $<0.2$ & $<0.2$ \\
\hline $\begin{array}{c}\text { BK-73-46-804 } \\
\text { (Window } \\
\text { Spring) }\end{array}$ & $08-25-87$ & $<.2$ & $<.2$ & $<.2$ & $<.2$ & $<.2$ & $<.2$ & $<.2$ & $<.2$ & $<.2$ \\
\hline $\begin{array}{l}\text { National Park } \\
\text { Service, Big } \\
\text { Bend lower } \\
\text { sewage } \\
\text { lagoon }\end{array}$ & $08-26-87$ & $<.2$ & $<.2$ & $<.2$ & $<.2$ & $<.2$ & $<.2$ & $<.2$ & $" \quad<.2$ & $<.2$ \\
\hline $\begin{array}{l}\text { Local } \\
\text { Identifier }\end{array}$ & Date & Time & $\begin{array}{l}\text { Aldrin, } \\
\text { total } \\
(\mu g / L)\end{array}$ & 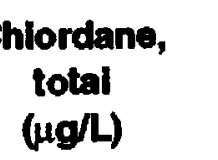 & $\begin{array}{l}\text { DDD, } \\
\text { lotal } \\
(\mu g /)\end{array}$ & $\begin{array}{l}\text { DDE, } \\
\text { total } \\
(\mu g / L)\end{array}$ & $\begin{array}{l}\text { DDT, } \\
\text { total } \\
(\mu g / L)\end{array}$ & $\begin{array}{l}\text { leldrin, } \\
\text { total } \\
(\mu g / L)\end{array}$ & $\begin{array}{l}\text { dosulfan, } \\
\text { total } \\
(\mu g / L)\end{array}$ & 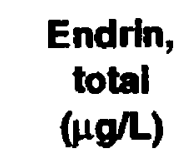 \\
\hline $\begin{array}{l}\text { BK-73-46-701 } \\
\text { (Oak } \\
\text { Spring) }\end{array}$ & $\begin{array}{l}06-24-86 \\
08-24-87\end{array}$ & $\begin{array}{l}1300 \\
1400\end{array}$ & $\begin{array}{r}<0.01 \\
<.01\end{array}$ & $\begin{array}{r}<0.1 \\
<.1\end{array}$ & $\begin{array}{r}<0.01 \\
<.01\end{array}$ & $\begin{array}{r}<0.01 \\
<.01\end{array}$ & $\begin{array}{r}<0.01 \\
<.01\end{array}$ & $\begin{array}{l}.0 .01 \\
<.01\end{array}$ & $\begin{array}{r}<0.01 \\
<.01\end{array}$ & $\begin{array}{l}<0.01 \\
<.01\end{array}$ \\
\hline
\end{tabular}


Tabie 4. Water-quality data for selected locations, The Basin and Oak Spring areas and Cattail Falls, 1954-89-Continued

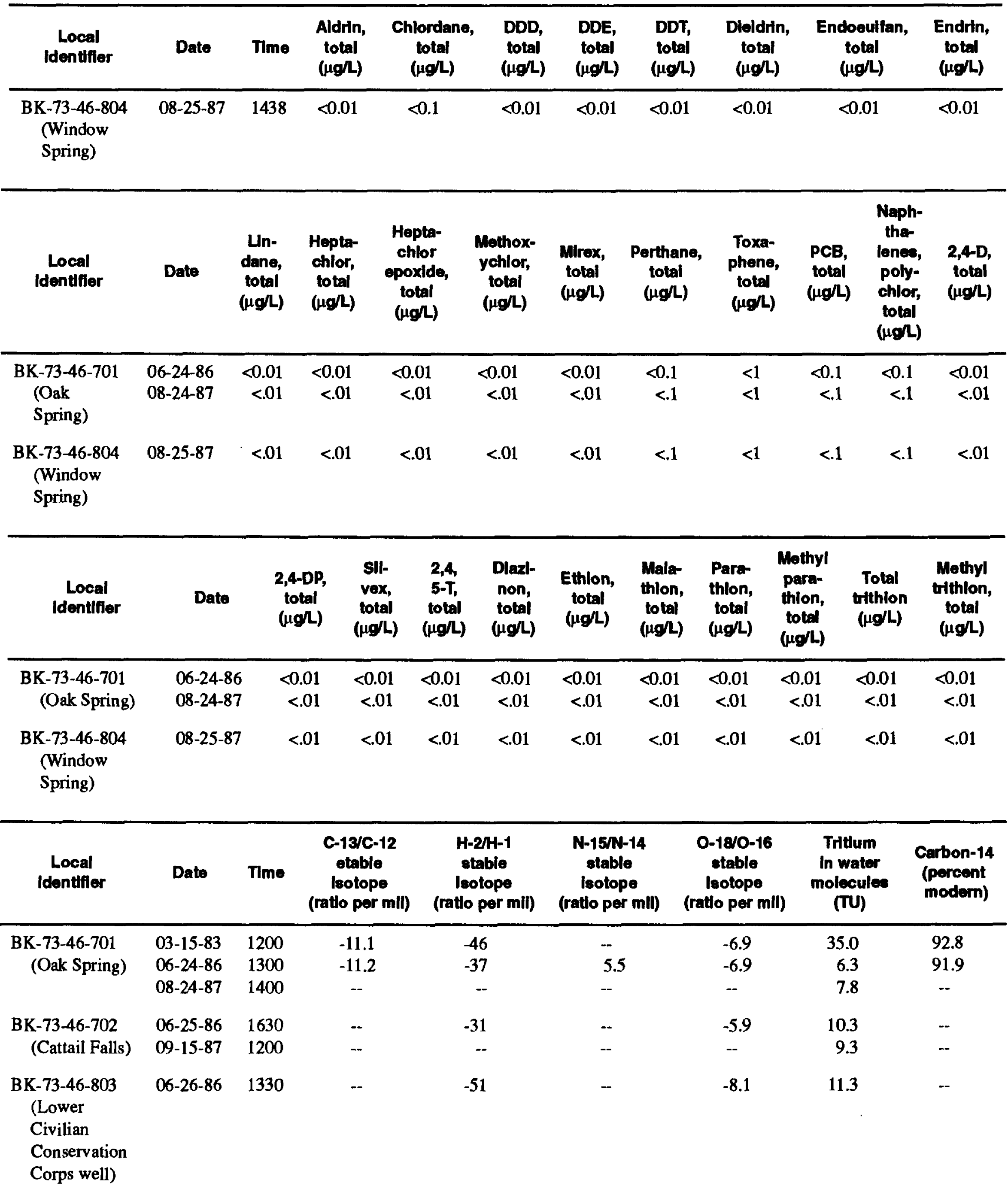


Table 4. Water-quality data for selected locations, The Basin and Oak Spring areas and Cattail Falls, 1954-89-Continued

\begin{tabular}{|c|c|c|c|c|c|c|c|c|}
\hline $\begin{array}{l}\text { Local } \\
\text { Identifior }\end{array}$ & Date & Time & $\begin{array}{c}\text { C-13/C-12 } \\
\text { stable } \\
\text { botope } \\
\text { (ratio per mIl) }\end{array}$ & $\begin{array}{c}\text { H-2/H-1 } \\
\text { stable } \\
\text { leotope } \\
\text { (ratio per mIl) }\end{array}$ & $\begin{array}{c}\text { N-15/N-14 } \\
\text { stable } \\
\text { lootope } \\
\text { (ratio per mll) }\end{array}$ & $\begin{array}{c}\text { 0-18/0-16 } \\
\text { stable } \\
\text { lootope } \\
\text { (ratio per } \mathrm{mll} \text { ) }\end{array}$ & $\begin{array}{l}\text { Tritium } \\
\text { In water } \\
\text { molecules } \\
\text { (TU) }\end{array}$ & $\begin{array}{c}\text { Carbon-14 } \\
\text { (percent } \\
\text { modom) }\end{array}$ \\
\hline BK-73-46-804 & $06-25-86$ & 1510 & -- & -38 & 5.2 & 5.2 & 11.3 & -- \\
\hline $\begin{array}{l}\text { (Window } \\
\text { Spring) }\end{array}$ & $08-25-87$ & 1438 & -- & -- & - & -- & 9.3 & -- \\
\hline
\end{tabular}

